\title{
Uranium Industry Annual 1995
}

May 1996
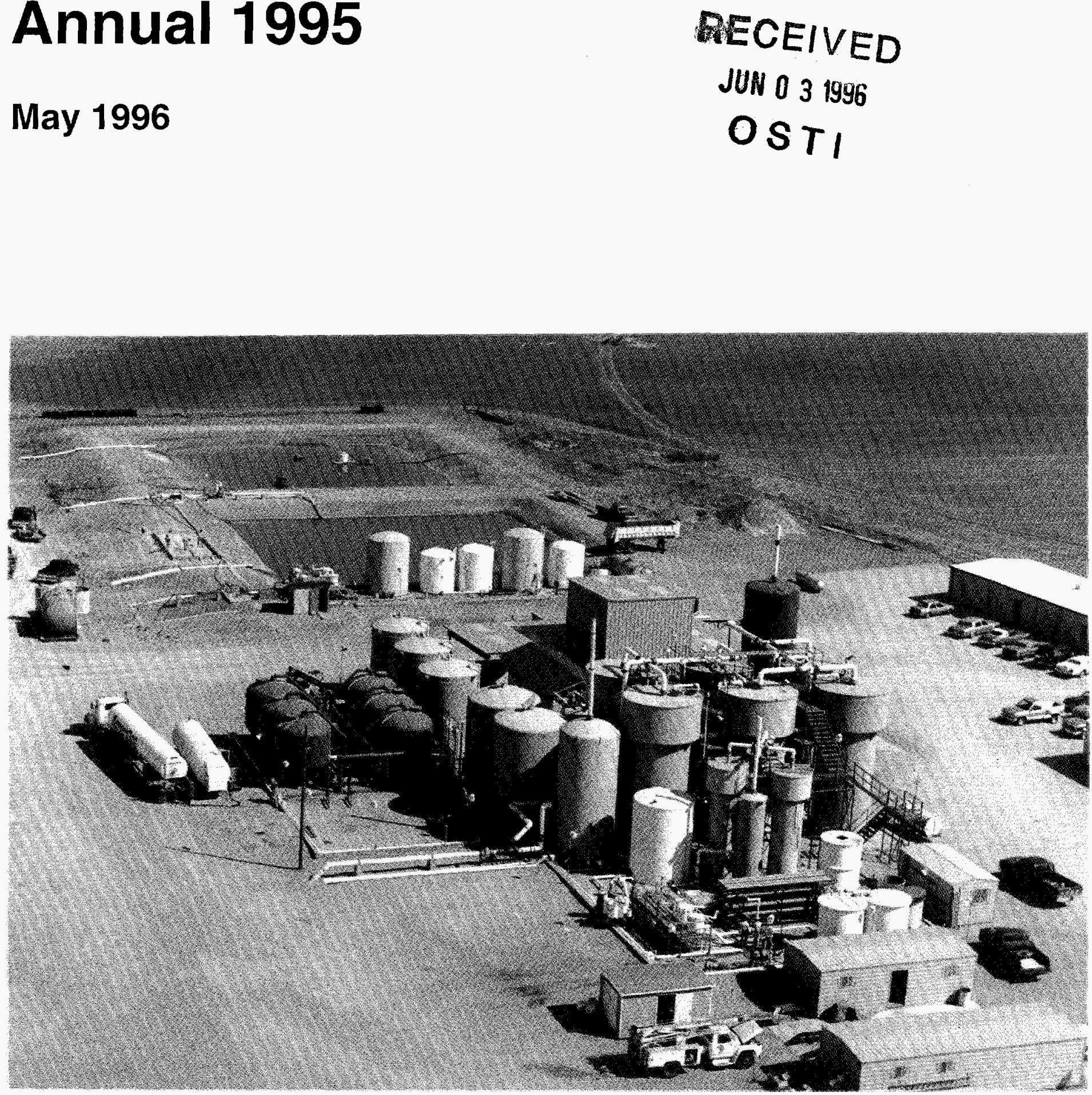


\section{EIA DATA IS AVAILABLE IN ELECTRONIC AND PRINTED FORM}

For information on the following electronic products and services, contact the National Energy Information Center on (202) 586-8800 or infoctr@eia.doe.gov

Internet Site Services - offer nearly all EIA publications. Users can view and download selected pages or entire reports, search for information, download EIA data and analysis applications, and find out about new EIA information products and services.

World Wide Web: http://www.eia.doe.gov

Gopher: gopher://gopher.eia.doe.gov

FTP: ftp://ftp.eia.doe.gov

EIA also offers a listserv service for EIA press releases and other short documents. Sign up on the EIA World Wide Web site.

EIA's CD-ROM, Energy InfoDisc, produced quarterly, contains most EIA publications, several databases, and an energy forecasting model. It is available for a fee from STAT-USA, Department of Commerce, 1-800-STAT-USA.

The Comprehensive Oil and Gas Information Source (COGIS), a bulletin board service, contains data files from most of EIA's oil- and gas-related reports. It is available for a fee from STAT-USA, on 1-800-STAT-USA.

EIA's Electronic Publishing System (EPUB) bulletin board contains data files, directories, and forecasts from most EIA reports. It can be accesssed free of charge by dialing (202) 586-2557.

Recent publications may be purchased

Older publications may be purchased from: from:

Superintendent of Documents

U.S. Government Printing Office

P.O. Box 371954

Pittsburgh, PA 15250-7954
National Technical Information Service

U.S. Department of Commerce

5285 Port Royal Road

Springfield, VA 22161

(202) $512-1800$

(703) $487-4650$

(202) $512-2250$ (fax)

(703) $321-8547$ (fax)

For further information on any of the above information sources, or for answers to questions on energy statistics, please contact EIA's National Energy Information Center:

National Energy Information Center

Energy Information Administration

Forrestal Building, Room 1F-048

Washington, DC 20585
(202) 586-8800

(202) 586-0727 (fax)

TTY: (202) 586-1181

Email: infoctr@eia.doe.gov

Cover Photo: Uranium Resource's Kingsville Dome ISL plant located in Kleberg County, Texas, which shows the plant complex in the lower area of the photo, and the evaporation ponds in the upper portion of the photograph. (credit: Uranium Resources, Inc.) 


\title{
Uranium Industry Annual 1995
}

\author{
May 1996
}

\section{DISCLAIMER}

\begin{abstract}
This report was prepared as an account of work sponsored by an agency of the United States Government. Neither the United States Government nor any agency thereof, nor any of their employees, makes any warranty, express or implied, or assumes any legal liability or responsibility for the accuracy, completeness, or usefulness of any information, apparatus, product, or process disclosed, or represents that its use would not infringe privately owned rights. Reference herein to any specific commercial product, process, or service by trade name, trademark, manufacturer, or otherwise does not necessarily constitute or imply its endorsement, recommendation, or favoring by the United States Government or any agency thereof. The views and opinions of authors expressed herein do not necessarily state or reflect those of the United States Government or any agency thereof.
\end{abstract}

\section{Energy Information Administration \\ Office of Coal, Nuclear, Electric and Alternate Fuels \\ U.S. Department of Energy \\ Washington, DC 20585}

This report was prepared by the Energy Information Administration, the independent statistical and analytical agency of the Department of Energy. The information contained herein should not be construed as advocating or reflecting the position of the Department of Energy or of any other organization.

\section{DISTRIBUTION OF THIS DOCUMENT IS UNLIMITED}

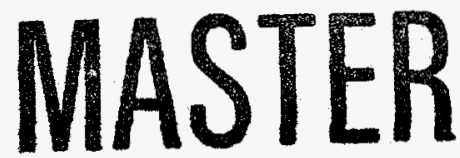




\section{Contacts}

This report was prepared by the Energy Information Administration (EIA), Office of Coal, Nuclear, Electric and Alternate Fuels. General information about this document may be obtained from the National Energy Information Center (202/586-8800), or John C. Geidl (202/426-1200), Director of the Office of Coal, Nuclear, Electric and Alternate Fuels, and Robert M. Schnapp (202/426-1211), Director of the Analysis and Systems Division. Technical information about this report may be obtained from $Z$. $D$. Nikodem (202/426-1179), Chief of the Nuclear Fuel Cycle Branch.

Specific questions regarding the various sections of the report should be addressed to the following staff personnel and/or section authors:
Exploration, production, employment, and marketing activities:

Douglas Bonnar on (202) 426-1249; or email address: dbonnar@eia.doe.gov

Reserves and Resources:

Taesin Chung on (202) 426-1128; or email address: tchung@eia.doe.gov

Survey methodology and operations:

Charles Johnson on (202) 426-1178;

or email address: cjohnson@eia.doe.gov. 


\section{Preface}

The Uranium Industry Annual 1995 (UIA 1995) provides current statistical data on the U.S. uranium industry's activities relating to uranium raw materials and uranium marketing. The UIA 1995 is prepared for use by the Congress, Federal and State agencies, the uranium and nuclear electric utility industries, and the public. It contains data for the period 1986 through 2005 as collected on the Form EIA-858, "Uranium Industry Annual Survey."

Data collected on the "Uranium Industry Annual Survey" provide a comprehensive statistical characterization of the industry's activities for the survey year and also include some information about industry's plans and commitments for the near-term future. Where aggregate data are presented in the UIA 1995, care has been taken to protect the confidentiality of company-specific information while still conveying accurate and complete statistical data.

The legal authority for Form EIA-858, "Uranium Industry Annual Survey," comes from Section 13b of the Federal Energy Administration Act of 1974 (15 U.S.C. 2210b).

On October 24, 1992, the Congress enacted the Energy Policy Act of 1992 (EPACT 1992), Public Law 102-486. This law provides under Subtitle B, 42 USC $\S 2296 \mathrm{~b}-4$, Sec. 1015, that:

"... the owner or operator of any civilian nuclear power reactor shall report to the Secretary (of Energy), acting through the Administrator of the Energy Information Administration, for activities of the previous fiscal year-
(1) the country of origin and the seller of any uranium or enriched uranium purchased or imported into the United States either directly or indirectly by such owner or operator; and

(2) the country of origin and the seller of any enrichment services purchased by such owner or operator."

The information is required to be made available to the Congress annually.

Data on uranium raw materials activities for 1986 through 1995 including exploration activities and expenditures, EIA-estimated reserves, mine production of uranium, production of uranium concentrate, and industry employment are presented in Chapter 1. Data on uranium marketing activities for 1994 through 2005, including purchases of uranium and enrichment services, enrichment feed deliveries, uranium fuel assemblies, filled and unfilled market requirements, uranium imports and exports, and uranium inventories are shown in Chapter 2.

The methodology used in the 1995 survey, including data edit and analysis, is described in Appendix A. The methodologies for estimation of resources and reserves are described in Appendix B. A list of respondents to the "Uranium Industry Annual Survey" is provided in Appendix C. For the readers convenience, metric versions of selected tables from Chapters 1 and 2 are presented in Appendix D along with the standard conversion factors used. A glossary of technical terms is at the end of the report. 


\section{Contents}

Page

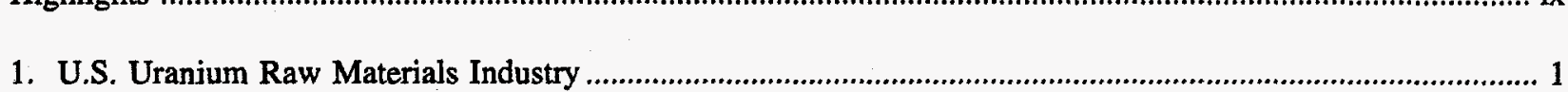

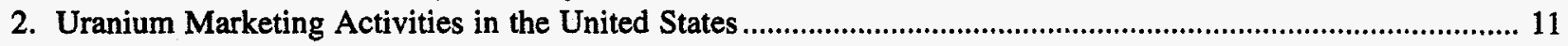

\section{Appendices}

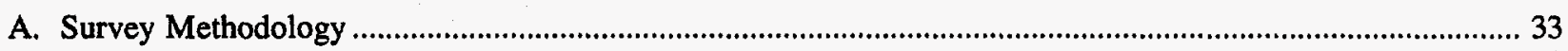

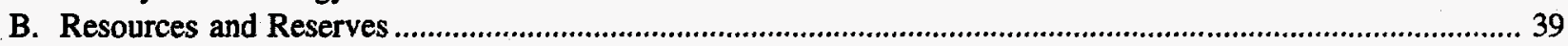

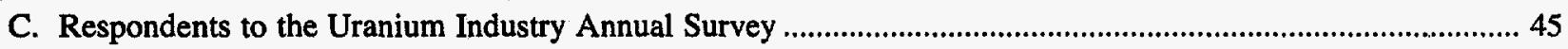

D. U.S. Customary Units of Measurement, International System of Units (SI), and Selected Data Tables in SI Metric Units

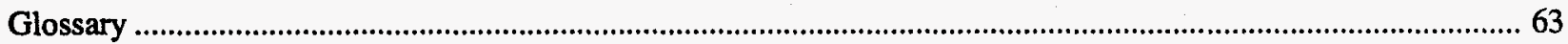


Table 1. U.S. Uranium Land and Surface Drilling Activities, 1986-1995 .................................. 5

Table 2. Expenditures for Exploration and Development of Uranium in the United States, 1986-1995

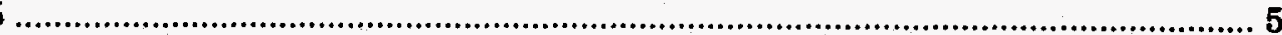

Table 3. Forward-Cost Uranium Reserves by Mining Method, 1995 ............................................ 6

Table 4. U.S. Uranium Mine Production and Number of Mines and Sources, 1986-1995 ................ 6

Table 5. U.S. Uranium Concentrate Processing Operations, 1986-1995 ........................................ 7

Table 6. Operating Status of Conventional Uranium Mills, End of the Year, 1992-1995 ................. 8

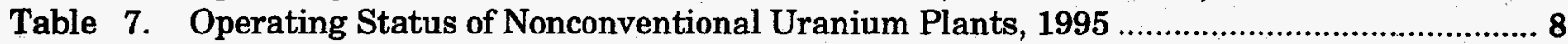

Table 8. Employment in the U.S. Uranium Industry by Category, 1986-1995 ............................... 9

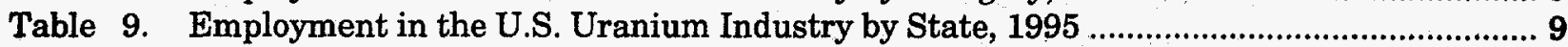

Table 10. U.S. Utilities Contracted Uranium by Supplier, Transaction Type, and Delivery Year, 1994-1995

Table 11. U.S. Utilities Contracted Uranium by Transaction Type and Delivery Year, 1994-1995

Table 12. U.S. Utilities Purchases of Uranium by Origin Country and Delivery Year, 1994-1995

Table 13. U.S. Utilities Contracted Uranium by Transaction Type, Material Type, and

Delivery Year 1995

Table 14. Average Price and Quantity for Purchases of Uranium by U.S. Utilities by Pricing Mechanisms and Delivery Year, 1994-1995

Table 15. Price Distributions of Uranium Purchases by U.S. Utilities by Delivery Year, 1994-1995

Table 16. U.S. Utility Uranium Purchases by Contract Type and Material Type, 1995 ................. 21

Table 17. New Contracts Signed by U.S. Utilities in 1995 by Contract Type and Delivery

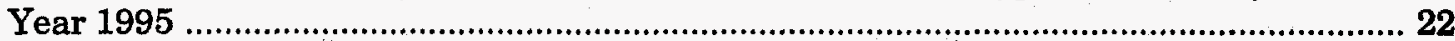

Table 18. U.S. Utilities New Contracted Purchases of Uranium by Delivery Year, 1996-2005 ....... 22

Table 19. U.S. Utilities Contracted Purchases of Uranium from Suppliers, in Effect at the End of 1995, by Delivery Year, 1996-2005 ....................................................................... 23

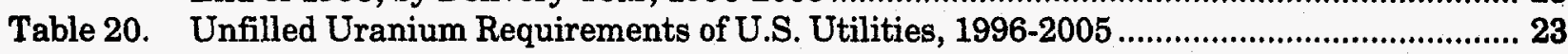

Table 21. Anticipated Uranium Market Requirements of U.S. Utilities, 1996-2005, as of December 31, 1995

Table 22. U.S. Utilities Deliveries of Uranium Feed by Enrichment Country and Delivery Year, 1994-1995

Table 23. U.S. Utilities Deliveries of Uranium Feed for Enrichment by Origin Country and Delivery Year, 1994-1995

Table 24. Shipments of Uranium by U.S. Utilities to Domestic and Foreign Enrichment Suppliers, 1996-2005

Table 25. U.S. Utilities Purchases of Enrichment Services by Country and Delivery Year, 1994-1995

Table 26. U.S. Utilities Purchases of Enrichment Services by Contract Type in

Delivery Year 1995

Table 27. Uranium Loaded into Fuel Assemblies for Commercial Nuclear Reactors by

Year, 1994-1995

Table 28. Imports of Uranium by U.S. Suppliers, U.S. Utilities and Delivery Year, 1994-1995 ...... 27

Table 29. U.S. Brokers and Traders Purchases of Uranium by Material Origin, Supplier, and Delivery Year, 1994-1995

Table 30. Uranium Exports to Foreign Suppliers and Utilities by Origin and Delivery Year, 1994-1995

Table 31.

Inventories of Natural and Enriched Uranium as of End of Year, 1994-1995.

Table 32.

Table 33. Commercial Uranium Inventories by Type and Location at End of Year, 1994-1995 
Table B2. U.S. Potential Uranium Resources by Forward-Cost Category and Resource Region, 1995

Table B3. U.S. Uranium Reserves by Forward-Cost Category, 1986-1995 ….............................. 42

Table B4. Forward-Cost Uranium Reserves by State, 1995 ..................................................... 42

Table C1. Respondents to the 1995 Uranium Industry Annual Survey ................................... 45

Table D1. Conversion Factors for U.S. Customary Units and SI Metric Units of Measurement ..... 49

Table D2. U.S. Uranium Land and Surface Drilling Activities, 1986-1995 ................................ 51

Table D3. Forward-Cost Uranium Reserves by Mining Method, 1995 .................................... 51

Table D4. U.S. Uranium Mine Production and Number of Mines and Sources, 1986-1995 ............. 52

Table D5. U.S. Uranium Concentrate Processing Operations, 1986-1995 .................................... 53

Table D6. U.S. Utilities Contracted Uranium by Supplier, Transaction Type, and

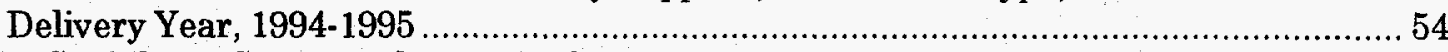

Table D7. U.S. Utilities Contracted Uranium by Transaction Type and Delivery Year, 1994-1995

Table D8. U.S. Utilities Purchases of Uranium by Origin Country and Delivery Year, 1994-1995

Table D9. Average Price and Quantity for Purchases of Uranium by U.S. Utilities by Pricing Mechanisms and Delivery Year, 1994-1995

Table D 10. U.S. Utilities Contracted Purchases of Uranium from Suppliers, in Effect at the End of 1995, by Delivery Year, 1996-2005

Table D11. Anticipated Uranium Market Requirements of U.S. Utilities, 1996-2005, as of December 31, 1995

Table D12. U.S. Utilities Deliveries of Uranium Feed by Enrichment Country and Delivery Year, 1994-1995 ..................................................................................... 57

Table D13. Uranium Loaded into Fuel Assemblies for Commercial Nuclear Reactors by Year, 1994-1995

Table D 14. Imports of Uranium by U.S. Suppliers, U.S. Utilities and Delivery Year, 1994-1995

Table D15. U.S. Brokers and Traders Purchases of Uranium by Material Origin, Supplier, and Delivery Year, 1994-1995

Table D16. Uranium Exports to Foreign Suppliers and Utilities by Origin and Delivery Year, 1994-1995

Table D17. Inventories of Natural and Enriched Uranium as of End of Year, 1994-1995

Figures

Figure 1. Exploration and Development Expenditures, 1986 - 1995 ..................................... 3

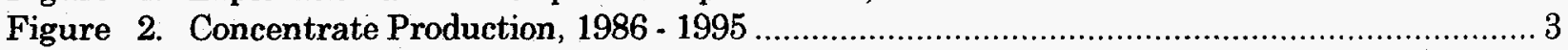

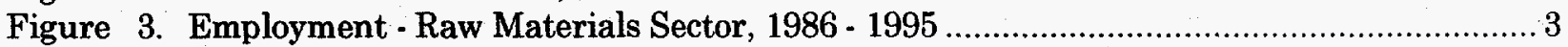

Figure 4. Major U.S. Uranium Reserve Areas and Status of Mills and Plants, 1995 .................. 4

Figure 5. Uranium Marketing Activity During 1995 ........................................................... 14

Figure 6. U.S. Utilities Purchases of Uranium by Origin and Delivery Year, 1994 - $1995 \ldots \ldots \ldots \ldots \ldots 15$

Figure 7. Purchases of Uranium by Selected Country Origin and Delivery Year, 1995 ................ 15

Figure 8. Purchases of Uranium by Material Type and Delivery Year, 1995 ............................ 15

Figure 9. Anticipated Uranium Market Requirements of U.S. Utilities, 1996 - 2005 ................. 16

Figure 10. Natural Uranium Feed for Enrichment by Delivery Year, 1994 - 1995 ........................ 16

Figure 11. Uranium Used in Fuel Assemblies for U.S. Commercial Nuclear Reactors,

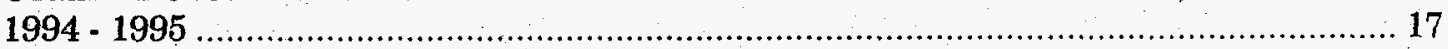

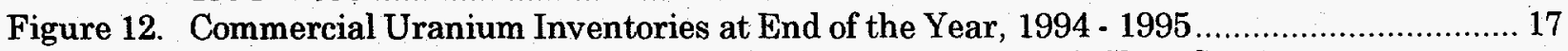

Figure B1. Comparison of Historical and Current U.S. and NEAIAEA Classification

Nomenclatures for Uranium Resources ............................................................... 40

Figure B2. Uranium Resource Regions of the United States.............................................. 40 


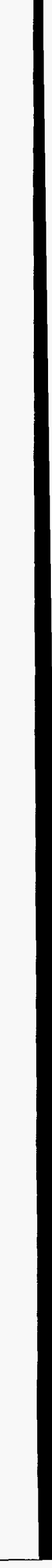




\section{Highlights}

1995 was a turnaround year for the U.S. uranium industry. Domestic uranium mine and concentrate production were at their highest levels in four years. The following are highlights of the year.

\section{Uranium Raw Material Activities}

Uranium production (in the form of uranium concentrate) in 1995 totaled 6.0 million pounds $\mathrm{U}_{3} \mathrm{O}_{8}$, an increase of 80 percent from the 1994 level, and the highest level since 1991 (Table H1). Eight uranium concentrate production facilities were commercially operating at the end of 1995: one mill, five in situ leach plants, and two byproduct recovery plants. Conventional mills accounted for 27 percent of the total production, and nonconventional plants accounted for 73 percent. The one commercial operating mill produced uranium concentrate from stockpiled ores, mined prior to 1993 . Uranium concentrate shipments from U.S. producers were 5.5 million pounds in 1995, a decrease of 13 percent compared with the 1994 shipments.

During 1995, a total of 3.5 million pounds $\mathrm{U}_{3} \mathrm{O}_{8}$ of uranium were produced by U.S. mines. This is the highest level of production since 1991. Most of that amount was by in situ leach methods. Compared with 1994,1995 production represents an increase of 38 percent. However, it was the third consecutive year in which no ore was mined from openpit or in underground mines.

Total exploration and development expenditures in 1995 were $\$ 6.0$ million, a 64-percent increase from 1994, due to a significant increase in surface drilling activities. Foreign participation in U.S. uranium exploration and development activities was $\$ 2.1$ million, and represented 35 percent of the total expenditures.

Employment in the raw materials sector of the uranium industry increased during 1995 by 13 percent to 1,107 person years. This is the third consecutive year of increasing employment. The reclamation sector employment accounted for more than half of this total.

\section{Uranium Marketing Activities}

\section{Purchases}

Domestic and foreign suppliers delivered a total of 43.4 million pounds $\mathrm{U}_{3} \mathrm{O}_{8}$ e (equivalent) to U.S. utilities in 1995 (Table H2). Utilities were delivered 13 percent more uranium, compared with the 1994 level. The average price paid by the utilities was $\$ 11.25$ per pound $\mathrm{U}_{3} \mathrm{O}_{8} \mathrm{e}$, an increase of 8 percent compared with the 1994 price.

Deliveries of uranium to U.S. brokers and traders totaled 22.9 million pounds $\mathrm{U}_{3} \mathrm{O}_{8} \mathrm{e}$ in 1995 . The average price for these purchases was $\$ 9.53$ per pound, an increase of 15 percent compared with the 1994 price.

\section{Imports and Exports}

In 1995, purchases from foreign suppliers by U.S. suppliers and utilities totaled 41.3 million pounds $\mathrm{U}_{3} \mathrm{O}_{8} \mathrm{e}$, at an average price of $\$ 10.20$ per pound (Table $\mathrm{H} 2$ ). This represents an increase of 14 percent compared with the 1994 price.

Uranium exported to foreign suppliers and utilities was 9.8 million pounds, at an average price of $\$ 13.48$ per pound. Compared with 1994 , the quantity was 45 percent lower.

\section{Uranium in Fuel Assemblies}

Utilities loaded fuel assemblies that contained 51.1 million pounds $\mathrm{U}_{3} \mathrm{O}_{8} \mathrm{e}$ into U.S. commercial nuclear reactors during $1995,10.7$ million pounds more than in 1994 (Table H3).

\section{Inventories}

Uranium inventories held by U.S. utilities continued to decline in 1995 reaching 56.2 million pounds $\mathrm{U}_{3} \mathrm{O}_{8} \mathrm{e}$ at the end of the year (Table H3). This represented a 14 percent decrease from the level of inventories at the end of 1994 and was 65 percent below the record-high level of inventories held by utilities at the end of 1984 (160.2 million pounds). 
Table H1. Raw Materials Summary Statistics of the U.S. Uranium Industry, 1986-1995

\begin{tabular}{|c|c|c|c|c|c|c|c|c|c|c|}
\hline Processing Operations & 1986 & 1987 & 1988 & 1989 & 1990 & 1991 & 1992 & 1993 & 1994 & 1995 \\
\hline \multicolumn{11}{|l|}{ Exploration and Development } \\
\hline Surface Drilling (million feet) ........ & 2.1 & 2.0 & 3.0 & 2.2 & 1.7 & 1.8 & 1.1 & 1.1 & 0.7 & 1.3 \\
\hline eters) & 0.6 & 0.6 & 0.9 & 0.7 & 0.5 & 0.6 & 0.3 & 0.3 & 0.2 & 0.4 \\
\hline Expenditures ${ }^{a}$ (million dollars) ..................... & 22.1 & 19.7 & 20.1 & 14.8 & 17.1 & 17.8 & 14.5 & 11.3 & 3.7 & 6.0 \\
\hline \multicolumn{11}{|l|}{$\begin{array}{l}\text { Reserves at End of Year } \\
\text { (million pounds } \mathrm{U}_{3} \mathrm{O}_{8}\end{array}$} \\
\hline $\begin{array}{l}\$ U S 30 \text { per pound) } \\
\text { (thousand metric tons } U \text {, }\end{array}$ & 322 & 304 & 289 & 277 & 265 & 304 & 295 & 292 & 294 & 290 \\
\hline$\$$ US80 per kilogram) & 124 & 117 & 111 & 107 & 102 & 117 & 114 & 112 & 113 & 112 \\
\hline \multicolumn{11}{|l|}{ Mine Production of Uranium } \\
\hline (million pounds $\mathrm{U}_{3} \mathrm{O}_{8}$ ) $\ldots \ldots \ldots \ldots$ & 8.3 & 6.0 & 9.5 & 9.7 & 5.9 & 5.2 & 1.0 & 2.0 & 2.5 & 3.5 \\
\hline 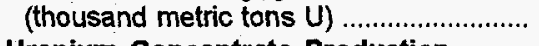 & 3.2 & 2.3 & 3.7 & 3.7 & 2.3 & 2.0 & 0.4 & 0.8 & 1.0 & 1.4 \\
\hline \multicolumn{11}{|l|}{ Uranium Concentrate Production } \\
\hline (million pounds $\mathrm{U}_{3} \mathrm{O}_{8}$ ) & 13.5 & 13.0 & 13.1 & 13.8 & 8.9 & 8.0 & 5.6 & 3.1 & 3.4 & 6.0 \\
\hline (thousand metric tons $U$ ) ................. & 5.2 & 5.0 & 5.0 & 5.3 & 3.4 & 3.1 & 2.2 & 1.2 & 1.3 & 2.3 \\
\hline \multicolumn{11}{|l|}{ Uranium Concentrate Shipments } \\
\hline (million pounds $\mathrm{U}_{3} \mathrm{O}_{8}$ ) & 10.6 & 11.6 & 12.8 & 14.8 & 13.0 & 8.4 & 6.9 & 3.4 & 6.3 & 5.5 \\
\hline & 4.1 & 4.4 & 4.9 & 5.7 & 4.9 & 3.2 & 2.6 & 1.3 & 2.4 & 2.1 \\
\hline Employment (person-years expended) ... & 2,120 & 2,002 & 2,141 & 1,583 & 1,335 & 1,016 & 682 & 871 & 980 & 1,107 \\
\hline
\end{tabular}

'Expenditures are in nominal U.S. dollars.

Note: Specific references for each category of data and year are provided in various detailed text or tables included in the main body of this report.

For 1993 through 1995, total employment includes reclamation employment.

Sources: Energy Information Administration: 1986-1994-Uranium industry Annnual 1994 (July 1995); 1995-Form ElA-858, "Uranium Industry Annual Survey" (1995).

Table H2. Transaction Summary Statistics of the U.S. Uranium Industry, 1994-1995

\begin{tabular}{|c|c|c|c|c|}
\hline \multirow[b]{2}{*}{ Actual Deliveries } & \multicolumn{2}{|c|}{1994} & \multicolumn{2}{|c|}{1995} \\
\hline & Quantity & $\begin{array}{l}\text { Weighted- } \\
\text { Average Price }\end{array}$ & Quantity & $\begin{array}{l}\text { Weighted- } \\
\text { Average Price }\end{array}$ \\
\hline 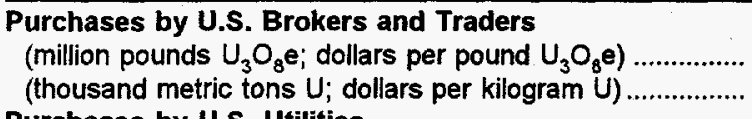 & $\begin{array}{l}30.8 \\
11.8\end{array}$ & $\begin{array}{r}8.29 \\
21.56\end{array}$ & $\begin{array}{r}22.9 \\
8.8\end{array}$ & $\begin{array}{r}9.53 \\
24.79\end{array}$ \\
\hline 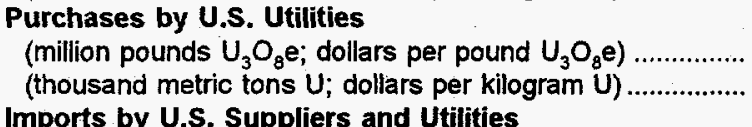 & $\begin{array}{l}38.3 \\
14.7\end{array}$ & $\begin{array}{l}10.40 \\
27.03\end{array}$ & $\begin{array}{l}43.4 \\
16.7\end{array}$ & $\begin{array}{l}11.25 \\
29.24\end{array}$ \\
\hline 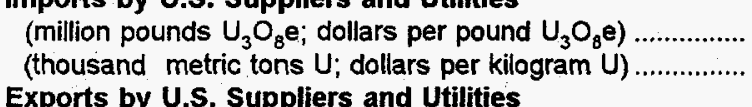 & $\begin{array}{l}36.6 \\
14.1\end{array}$ & $\begin{array}{r}8.95 \\
23.27\end{array}$ & $\begin{array}{l}41.3 \\
15.9\end{array}$ & $\begin{array}{l}10.20 \\
26.52\end{array}$ \\
\hline 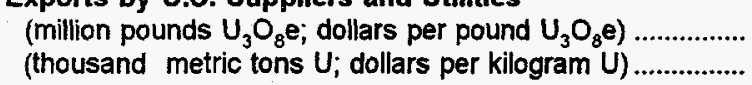 & $\begin{array}{r}17.7 \\
6.8\end{array}$ & $\begin{array}{l}11.34 \\
29.49\end{array}$ & $\begin{array}{l}9.8 \\
3.8\end{array}$ & $\begin{array}{l}13.48 \\
35.06\end{array}$ \\
\hline
\end{tabular}

$\mathrm{U}_{3} \mathrm{O}_{8} \mathrm{e}=\mathrm{U}_{3} \mathrm{O}_{8}$ equivalent.

Source: Energy Information Administration, Form EIA-858, "Uranium Industry Annual Survey" (1994-1995).

Table H3. Summary Statistics of Uranium Fuel and Inventories, 1994-1995

\begin{tabular}{|c|c|c|}
\hline Items & 1994 & $1995^{P}$ \\
\hline $\begin{array}{l}\text { Fuel Assemblies Loaded into Commercial Nuclear Reactors } \\
\text { (million pounds } \mathrm{U}_{3} \mathrm{O}_{8} \mathrm{e} \text { ) } \\
\text { (thousand metric tons } U \text { ) }\end{array}$ & $\begin{array}{l}\text { R40.4 } \\
\text { R15.5 }\end{array}$ & $\begin{array}{l}51.1 \\
19.7\end{array}$ \\
\hline $\begin{array}{l}\text { Commercial Inventories at the End of the Year } \\
\text { U.S. Utility Inventories } \\
\left.\text { (million pounds } \mathrm{U}_{3} \mathrm{O}_{8} \mathrm{e}\right) \\
\text { (thousand metric tons } \mathrm{U} \text { ) } \\
\text { U.S. Utility and Supplier Inventories }\end{array}$ & $\begin{array}{l}\text { R65.4 } \\
\text { R25.2 }\end{array}$ & $\begin{array}{l}56.2 \\
21.6\end{array}$ \\
\hline $\begin{array}{l}\left.\text { (million pounds } \mathrm{U}_{3} \mathrm{O}_{8} \mathrm{e}\right) \\
\text { (thousand metric tons } U \text { ) }\end{array}$ & $\begin{array}{l}\text { R86.9 } \\
\text { R33.4 }\end{array}$ & $\begin{array}{l}70.1 \\
27.0\end{array}$ \\
\hline
\end{tabular}

$\mathrm{U}_{3} \mathrm{O}_{8} \mathrm{e}=\mathrm{U}_{3} \mathrm{O}_{8}$ equivalent.

$P=$ Preliminary data. $R=$ Revised data. Final 1994 data reported in the 1995 survey.

Source: Energy Information Administration, Form ElA-858, "Uranium Industry Annual Survey" (1994-1995). 


\section{U.S. Uranium Raw Materials Industry}

\section{Introduction}

The levels of activity in the U.S. uranium raw materials industry were higher at the end of 1995 , compared with 1994. Expenditures for exploration, drilling, and related activities reported for 1995 . were more than in 1994 (Figure 1). Uranium concentrate production also increased in 1995 (Figure 2). Total employment for uranium exploration, mining, milling, and processing increased in 1995 compared with 1994 (Figure 3). Employment for reclamation activities has risen steadily since 1993.

Uranium concentrate was produced in 1995 from conventional milling, in situ leach methods, and as a byproduct of wet-process phosphoric acid manufacture. One conventional uranium mill was in commercial operation in 1995, and it milled ore stockpiled in years prior to 1993. Also, a small amount of uranium was recovered from the processing of mine water and other materials.

\section{Exploration and Development Activities}

\section{Land Holdings and Acquisitions}

U.S. uranium exploration companies held 259 thousand acres for all exploration purposes at the end of 1995 (Table 1). This represents the lowest amount of land held for exploration at year end since 1974 and is one tenth of the number of acres held in 1986. Only 7,000 acres were acquired for exploration at a total cost of $\$ 69$ thousand (Table 2). The types of land acquired and held include fee land, mineral fee leases, patented and unpatented mining claims, and options to purchase mineral fee land.

\section{Surface Drilling}

Surface drilling (exploration and development) in the United States was 1.3 million feet in 2,312 holes (Table 1). Development drilling footage in 1995 was 947 thousand feet, a three-fold increase compared with 1994, while exploration drilling footage increased slightly.

\section{Expenditures for Uranium Exploration and Development}

Total U.S. uranium exploration and development expenditures in 1995 were $\$ 6.0$ million, consisting of (in millions) $\$ 0.1$ for land, $\$ 2.6$ for surface drilling, and $\$ 3.4$ for other exploration activities (Table 2) This represents a 64 percent increase over the 1994 level, but only slightly more than half of the 1993 level. Participation from foreign sources to U.S. exploration expenditures in 1995 were $\$ 2.1$ million, which represents 35 percent of the total U.S. expenditures in 1995.

\section{Estimates of U.S. Uranium Reserves}

As of the end of 1995, the EIA's estimates of uranium reserves in the $\$ 30$ - and $\$ 50$-per-pound categories were 290 and 947 million pounds, respectively. Underground mining reserves accounted for about one-half of the total reserves in each cost category (Table 3). Three States, New Mexico, Texas and Wyoming, contained about 73 percent of \$30-per-pound $\mathrm{U}_{3} \mathrm{O}_{8}$ reserves (Appendix B, Table B4). Reserve estimates represent the quantities of uranium (as $\mathrm{U}_{3} \mathrm{O}_{8}$ ) that occur in known deposits such that portions of the mineralized deposits can be recovered at specific costs under current regulations using stateof-the art mining and milling methods. The specified forward-cost categories used for the reserves are not equivalent to current market prices.

\section{Mine Production of Uranium}

During 1995, a total of 3.5 million pounds $\mathrm{U}_{3} \mathrm{O}_{8}$ of uranium were produced by U.S. mines, the highest level of production since 1991 (Table 4). This is in contrast to 1991 and prior years when most of the production came from conventional (open pit and underground) mines. Other sources were recovery of uranium from waste mine water and from reclamation activities at closed in situ mine sites. Compared with 1994, in situ leach mine production increased 38 percent in 1995. For the third straight year, commercial mining at underground and openpit mines did not occur. 
There were five commercially operated in situ leach mines at the end of 1995, the same as in 1994 (Table 4). One in situ leach mine (Irigaray in Wyoming) was permanently shutdown and one (Rosita in Texas) resumed commercial operation during 1995.

\section{Concentrate Production and Shipments}

U.S. uranium concentrate production in 1995 was 6.0 million pounds $\mathrm{U}_{3} \mathrm{O}_{8}$, an increase of 80 percent above the 1994 level (Table 5). Concentrate production from conventional mills was 1.6 million pounds. This was the first year that uranium concentrate was produced commercially at conventional mills in the United States since 1992.

Concentrate production in the "Other Processing" category includes production from in situ leaching and as a byproduct of phosphate processing. Compared with 1994, this category increased 34 percent and totaled 4.4 million pounds $\mathrm{U}_{3} \mathrm{O}_{8}$ in 1995.

Shipments of uranium concentrate from domestic production facilities (mills, in situ and phosphate byproduct plants) totaled 5.5 million pounds in 1995 (Table 5). The total annual production of 6.0 million pounds exceeded annual shipments for the first year since 1988, which resulted in an overall increase of 0.5 million pounds in concentrate inventories held at production facilities at the end of 1995.

\section{Status of Uranium Processing Facilities}

At the end of 1995, one conventional mill in the United States was commercially producing uranium concentrate from stockpiled ores mined prior to 1993. This mill, White Mesa in Utah, has a capacity of 2,000 short tons of ore per day (Table 6). A small amount of uranium concentrate was recovered (at other mills) from processing of mine water and materials recovered from water treatment plants.

Seven nonconventional uranium producing plants, consisting of five in situ leach plants and two phosphate byproduct plants, were in commercial operation in the United States at the end of 1995 . These plants had a combined rated capacity of 6.4 million pounds $\mathrm{U}_{3} \mathrm{O}_{8}$ per year (Table 7). Eight nonconventional plants were inactive at the end of 1995 . Four of the six inactive in situ leach plants had produced a small amount of uranium concentrate in 1995 from reclamation activities. Two other in situ leach plants were on standby, with one having plans to restart in 1996. The two inactive byproduct plants in Florida were closed indefinitely.

The locations of active (commercially operating) and inactive U.S. uranium concentrate production facilities, along with the locations of major uranium reserve areas, are shown in Figure 4.

\section{Employment}

Employment in the U.S. uranium raw materials industry in 1995 was reported as 1,107 person years expended (Table 8). Compared with 1994, 1995 employment overall rose 13 percent: mining rose by 44 percent, milling by 15 percent, processing by 8 percent, and reclamation by 9 percent. However, exploration employment declined compared with 1994. For consecutive years since 1992, reclamation employment was more than the combined employment in uranium exploration, mining, milling and processing. Three States, Colorado, Texas and Wyoming, accounted for 65 percent of the total employment in 1995 (Table 9). 
Figure 1. Exploration and Development Expendltures, 1986 - 1995

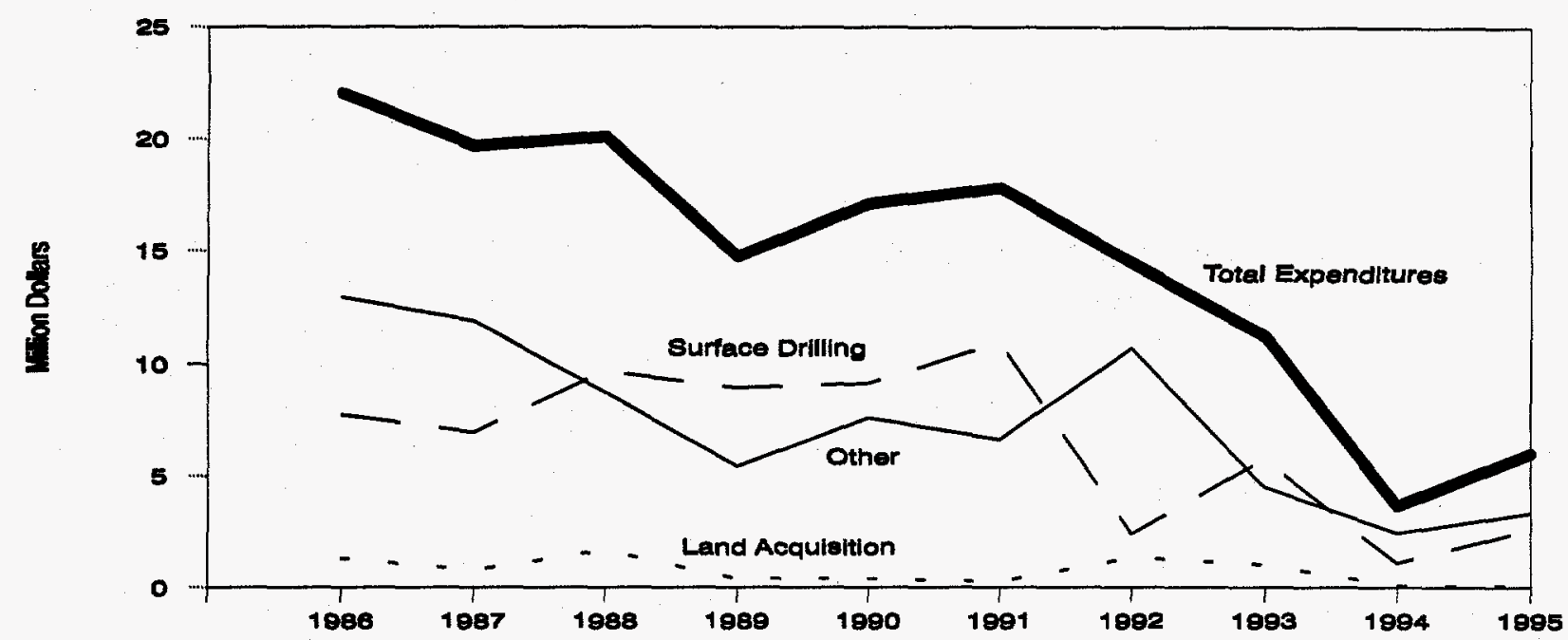

Figure 2. Concentrate Production, 1986 - 1995

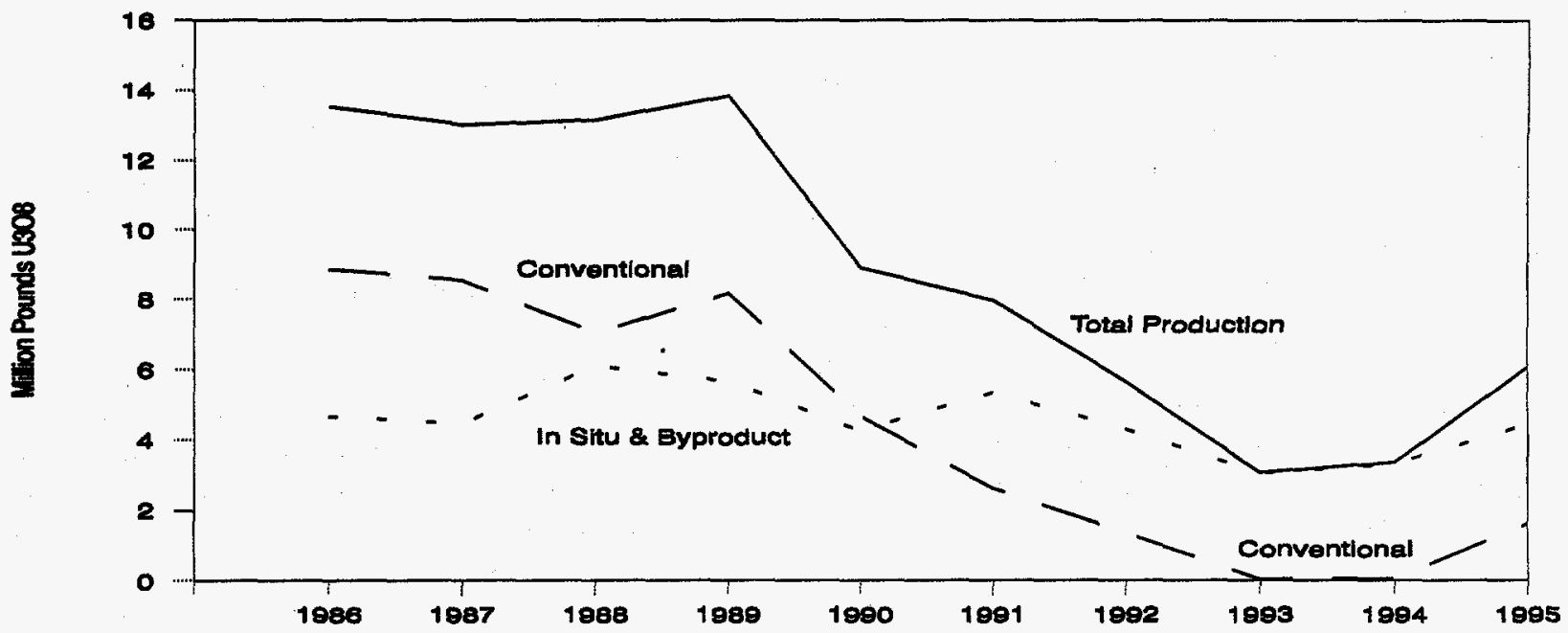

Figure 3. Employment - Raw Materials Sector, 1986 - 1995

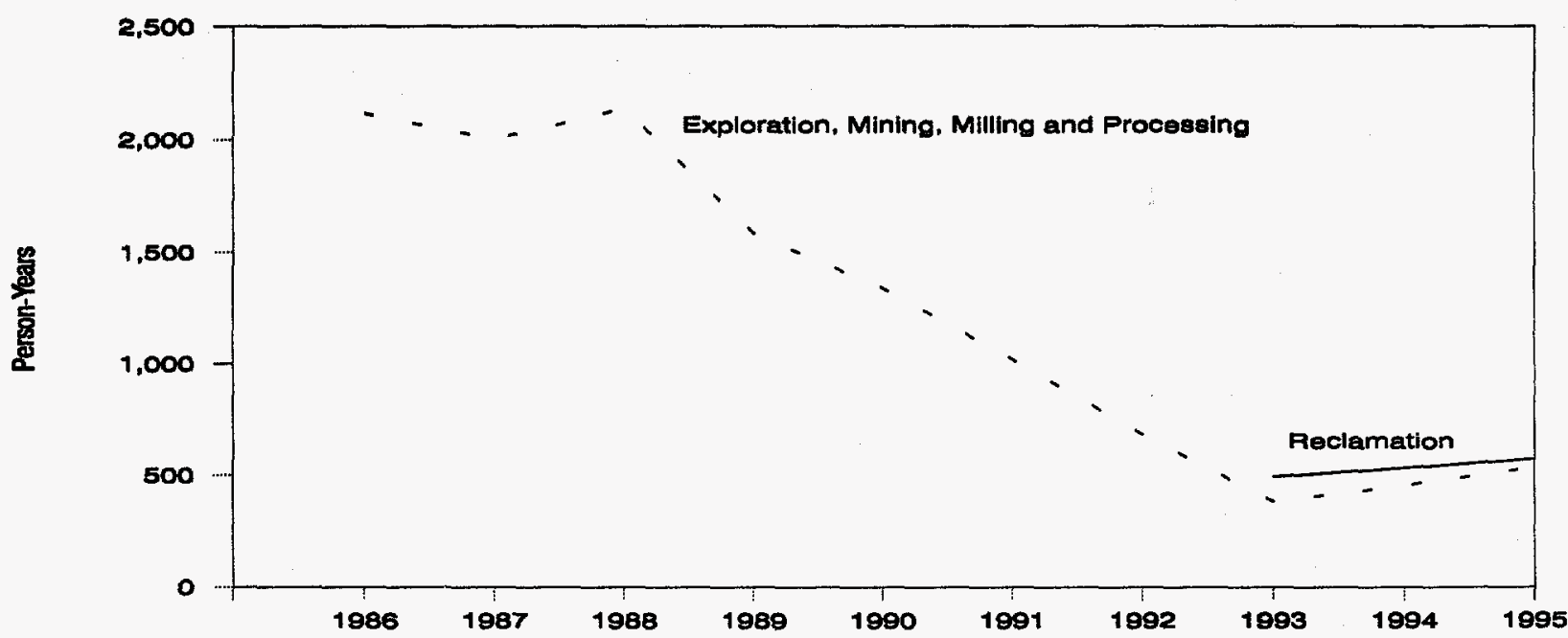

Sources: Energy Information Administration: 1986-1994-Uranium Industry Annual 1994 (July 1995). 1995-Form ElA-858, "Uranium Industry Annual Survey" (1995). 


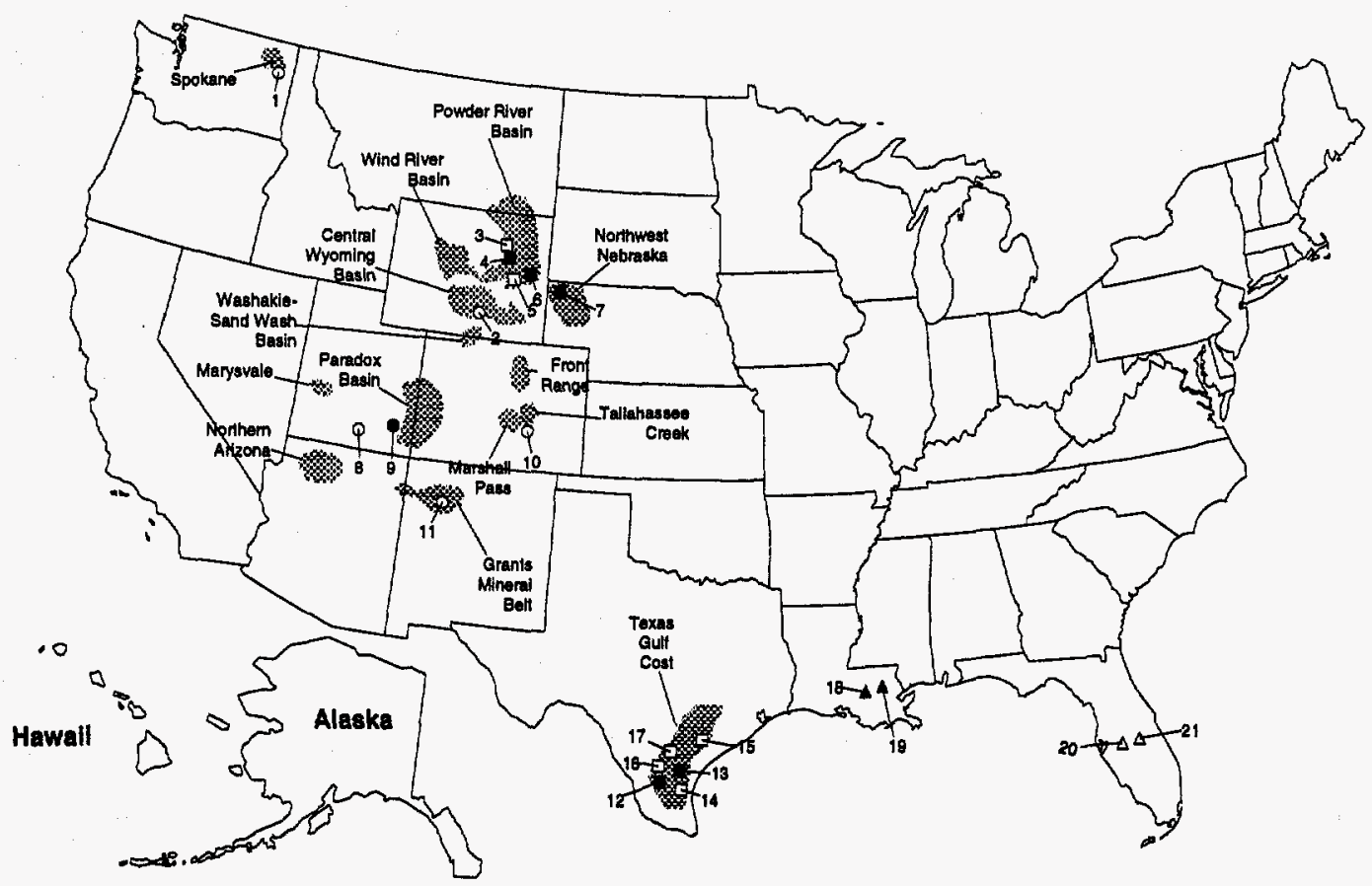

Active at the End of 1995

\footnotetext{
4. Malapai Resources, Christensen Ranch

6. Converse County Mining Venture, Highland

7. Crow Butte Resources, Crow Butte

9. Energy Fuels Nuclear, White Mesa

12. Malapai Resources, Hollday-El Mesquite

13. Uranium Resources, Rosita

18. IMC-Agrico, Sunshine Bridge

19. IMC-Agrico, Uncle Sam
}

\begin{tabular}{|cll|}
\hline Active & \multicolumn{2}{l|}{$\begin{array}{c}\text { Uranium Production Centers } \\
\text { Infetive }\end{array}$} \\
\hline & 0 & Conventional Mills \\
$\square$ & $\square$ & In Situ Leach Plant \\
$\Delta$ & $\Delta$ & Byproduct From Phosphate Processing \\
\hline & Major Uranlum Reserve Areas \\
\hline
\end{tabular}

\section{Inactlve at the End of 1995}

1. Dawn Mining, Ford

2. Green Mountain Mining Venture, Sweetwater

3. Malapai Resources, Irigaray

5. Rlo Aigom Mlning, Smith Ranch ${ }^{b}$

8. U.S. Energy, Shootaring

10. Cotter Corp. Canon Cly

11. Rio Algom Mining, Ambrosia

14. Uranium Resources, Kingsville Dome

14. Uranium Resources, Kingsv
15. Everest Minerals, Hobson b

16. COGEMA Mining, West Cole

17. Malapal Resources, O'Hern

20. IMC-Agrico, Plant City

21. IMC-Agrico, New Wales

-Recovered uranium by processing mine water or other materials from conventlonal mines during 1995.

bRecovered uranium by processing water Irom in situ leach mine restoration during 1995.

- Major areas containing reasonably assured resources at \$50-per-pound $U, 0$, or less.

Sources: Based on U.S. Department of Energy, Grand Junction Project Offlce (G.JPO), National Urainlum Resource Evaluation, Interim Report(June 1979) Figure 3.2; GJPO data flles; Energy Information Administration, Form ElA-858, "Uranium Industry Annual Survey" (1995); and site visits by staff of the Analysis and Systems Dlvision, Oftice of Coal, Nuclear, Electrlc and Altemate Fuel. 
Table 1. U.S. Uranium Land and Surface Drilling Activities, 1986-1995

\begin{tabular}{|c|c|c|c|c|c|c|c|c|c|c|c|}
\hline \multirow[b]{2}{*}{ Year } & \multicolumn{2}{|c|}{$\begin{array}{c}\text { Land } \\
\text { Exploration }\end{array}$} & \multicolumn{3}{|c|}{$\begin{array}{l}\text { Surface Drilling } \\
\text { Exploration }\end{array}$} & \multicolumn{3}{|c|}{$\begin{array}{l}\text { Surface Drilling } \\
\text { Development }\end{array}$} & \multicolumn{3}{|c|}{$\begin{array}{l}\text { Surface Drilling } \\
\text { Exploration and Development }\end{array}$} \\
\hline & $\begin{array}{l}\text { Acres } \\
\text { Acquired } \\
\text { during } \\
\text { Year } \\
\text { (thousand) }\end{array}$ & $\begin{array}{c}\text { Acres } \\
\text { Held } \\
\text { at End of } \\
\text { Year } \\
\text { (thousand) }\end{array}$ & $\begin{array}{c}\text { Number } \\
\text { of } \\
\text { Holes }\end{array}$ & $\begin{array}{c}\text { Feet } \\
\text { (thousand) }\end{array}$ & $\begin{array}{c}\text { Cost } \\
\text { (thousand } \\
\text { dollars) }\end{array}$ & $\begin{array}{c}\text { Number } \\
\text { of } \\
\text { Holes }\end{array}$ & $\begin{array}{c}\text { Feet } \\
\text { (thousand) }\end{array}$ & $\begin{array}{c}\text { Cost } \\
\text { (thousand } \\
\text { dollars) }\end{array}$ & $\begin{array}{c}\text { Number } \\
\text { of } \\
\text { Holes }\end{array}$ & $\begin{array}{c}\text { Feet } \\
\text { (thousand) }\end{array}$ & $\begin{array}{c}\text { Cost } \\
\text { (thousand } \\
\text { dollars) }\end{array}$ \\
\hline $1986 \ldots$ & 220 & 2,600 & 1,985 & 1,100 & 6,400 & 1,846 & 970 & 1,350 & 3,831 & 2,070 & 7,750 \\
\hline $1987 \ldots$ & 90 & 1,900 & 1,820 & 1,110 & 5,900 & 1,994 & 860 & 1,060 & 3,814 & 1970 & 6.960 \\
\hline $1988 \ldots$ & 90 & 1,700 & 2,029 & 1,280 & 6,440 & 3,176 & 1,730 & 3,260 & 5,205 & 3,010 & 9,700 \\
\hline $1989 \ldots$ & 28 & 1,529 & 2,087 & 1,430 & 5,820 & 1,753 & 800 & 3,120 & 3,840 & 2,230 & 8,940 \\
\hline $1990 \ldots$ & 38 & 1,209 & 1,507 & 870 & 3,210 & 1,908 & 810 & 5,950 & 3,415 & 1,680 & 9,160 \\
\hline $1991 \ldots$ & 32 & 1,060 & 1,624 & 973 & 2,832 & 1,573 & 869 & 8,114 & 3,197 & 1,842 & 10,946 \\
\hline $1992 \ldots$ & 85 & 788 & 935 & 562 & 1,267 & 833 & 502 & 1,162 & 1,768 & 1,064 & 2,429 \\
\hline $1993 \ldots$ & 65 & 455 & 355 & 223 & 983 & 1,665 & 885 & 4,754 & 2,020 & 1,108 & 5,737 \\
\hline $1994 \ldots$ & 9 & 325 & 519 & 341 & 736 & 477 & 316 & 383 & 996 & 657 & 1,119 \\
\hline $1995 \ldots$ & 7 & 259 & 584 & 402 & 790 & 1,728 & 947 & 1,799 & 2,312 & 1,348 & 2,589 \\
\hline
\end{tabular}

Note: Totals may not equal sum of components because of independent rounding

Sources: Energy Information Administration: 1986-1994-Uranium Industry Annual 1994(July 1995). 1995-Form EIA-858, "Uranium Industry Annual Survey" (1995).

Table 2. Expenditures for Exploration and Development of Uranium in the United States, 1986-1995 (Thousand Dollars)

\begin{tabular}{|c|c|c|c|c|c|c|}
\hline \multirow[b]{2}{*}{ Year } & \multirow[b]{2}{*}{$\begin{array}{l}\text { Surface } \\
\text { Drilling }\end{array}$} & \multirow[b]{2}{*}{$\begin{array}{l}\text { Land } \\
\text { Acquisition }\end{array}$} & \multirow{2}{*}{$\begin{array}{c}\text { Other } \\
\text { Exploration and } \\
\text { Development } \\
\text { Expenditures } \\
\end{array}$} & \multirow[b]{2}{*}{$\begin{array}{c}\text { Total U.S. } \\
\text { Expenditures }\end{array}$} & \multicolumn{2}{|c|}{ Forejgn Participation } \\
\hline & & & & & Expenditures & $\begin{array}{c}\text { Percent of Total } \\
\text { U.S } \\
\text { Expenditures }\end{array}$ \\
\hline $1986 \ldots \ldots \ldots \ldots . . . . . .$. & 7,740 & 1,330 & 12,990 & 22,060 & 12,000 & 54 \\
\hline $1987 \ldots \ldots \ldots \ldots$ & 6,960 & 790 & 11,920 & 19,670 & 11,900 & 60 \\
\hline $1988 \ldots \ldots \ldots \ldots . . . . .$. & 9,700 & 1,670 & 8,730 & 20,100 & 8,900 & 44 \\
\hline $1989 \ldots \ldots \ldots \ldots$ & 8,940 & 390 & 5,430 & 14,770 & 6,100 & 41 \\
\hline $1990 \ldots \ldots \ldots . . .$. & 9,150 & 400 & 7,580 & 17,120 & 2,530 & 15 \\
\hline 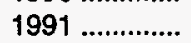 & 10,946 & 250 & 6,649 & 17,845 & 3,500 & 20 \\
\hline $1992 \ldots \ldots . . . . . .$. & 2,429 & 1,365 & 10,716 & 14,510 & 8,004 & 55 \\
\hline $1993 \ldots \ldots \ldots \ldots$ & 5,737 & 1,024 & 4,509 & 11,270 & 8,527 & 76 \\
\hline $1994 \ldots \ldots \ldots \ldots$ & 1,119 & 71 & 2,464 & 3,654 & 1,864 & 51 \\
\hline $1995 \ldots \ldots \ldots \ldots$ & 2,589 & 69 & 3,350 & 6,008 & 2,078 & 35 \\
\hline
\end{tabular}

Note: Totals may not equal sum of components because of independent rounding.

Sources: Energy Information Administration: 1986-1994-Uranium Industry Annual 1994 (July 1995). 1995-Form ElA-858, "Uranium Industry Annual Survey" (1995). 
Table 3. Forward-Cost Uranium Reserves by Mining Method, 1995

\begin{tabular}{|c|c|c|c|c|c|c|}
\hline \multirow[b]{3}{*}{ Mining Method } & \multicolumn{6}{|c|}{ Forward-Cost Category } \\
\hline & \multicolumn{3}{|c|}{$\$ 30$ per pound } & \multicolumn{3}{|c|}{$\$ 50$ per pound } \\
\hline & $\begin{array}{c}\text { Ore } \\
\text { (million tons) }\end{array}$ & $\begin{array}{c}\text { Grade } \\
\text { (percent } \mathrm{U}_{3} \mathrm{O}_{8} \text { ) }\end{array}$ & $\begin{array}{c}\mathrm{U}_{3} \mathrm{O}_{\mathrm{a}} \\
\text { (million pounds) }\end{array}$ & $\begin{array}{c}\text { Ore } \\
\text { (million tons) }\end{array}$ & $\begin{array}{c}\text { Grade } \\
\text { (percent } \mathrm{U}_{3} \mathrm{O}_{8} \text { ) }\end{array}$ & $\begin{array}{c}\mathrm{U}_{3} \mathrm{O}_{8} \\
\text { (million pounds) }\end{array}$ \\
\hline 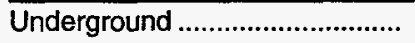 & 25 & 0.274 & 139 & 143 & 0.163 & 466 \\
\hline 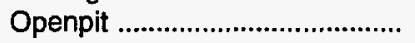 & 10 & 0.139 & 29 & 163 & 0.079 & 258 \\
\hline 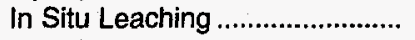 & 46 & 0.133 & 122 & 131 & 0.079 & 208 \\
\hline Other ${ }^{b}$ & $<1$ & 0.263 & $<1$ & 15 & 0.050 & 15 \\
\hline Total & 82 & 0.178 & 290 & 453 & 0.105 & 947 \\
\hline
\end{tabular}

aWeighted average percent $\mathrm{U}_{3} \mathrm{O}_{8}$ per ton of ore.

bIncludes heap leach, mine water, and low grade stockpiles.

Notes: Uranium reserves that could be recovered as a byproduct of phosphate and copper mining are not included in this table. Reserves values in forward-cost categories are cumulative: that is, the quantity at each level of forward-cost includes all reserves at the lower costs. Totals may not equal sum of components because of independent rounding.

Sources: Estimated by Energy Information Administration, Office of Coal, Nuclear, Electric and Alternate Fuels, based on industry conferences, U.S. Department of Energy, Grand Junction Projects Office data files, and Energy Information Administration, Form ElA-858, "Uranium Industry Annual Survey" (1995).

Table 4. U.S. Uranium Mine Production and Number of Mines and Sources, 1986-1995

\begin{tabular}{|c|c|c|c|c|c|c|c|c|c|c|}
\hline Mining Method & 1986 & 1987 & 1988 & 1989 & 1990 & 1991 & 1992 & 1993 & 1994 & 1995 \\
\hline $\begin{array}{l}\text { Underground } \\
\text { (thousand pounds } \mathrm{U}_{3} \mathrm{O}_{8} \text { ) } \ldots \ldots \ldots \ldots \ldots \ldots \ldots \ldots \ldots\end{array}$ & 6,400 & 4,900 & 5,400 & 5,300 & W & $w$ & W & 0 & 0 & 0 \\
\hline $\begin{array}{l}\text { Openpit } \\
\text { (thousand pounds } \mathrm{U}_{3} \mathrm{O}_{8} \text { ) } \ldots \ldots \ldots \ldots \ldots \ldots \ldots \ldots \ldots \ldots \ldots\end{array}$ & W & W & W & W & 1,881 & 2,528 & $w$ & 0 & 0 & 0 \\
\hline $\begin{array}{l}\text { In Situ Leaching } \\
\text { (thousand pounds } \mathrm{U}_{3} \mathrm{O}_{8} \text { ) }\end{array}$ & W & W & W & W & W & $w$ & W & W & 2,448 & 3,372 \\
\hline 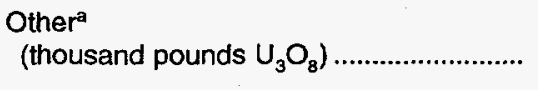 & 1,800 & 1,100 & 4,100 & 4,400 & 3,995 & 2,654 & 986 & 2,050 & 78 & 156 \\
\hline 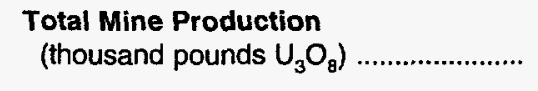 & 8,300 & 6,000 & 9,500 & 9,700 & 5,876 & 5,182 & 986 & 2,050 & 2,526 & 3,528 \\
\hline 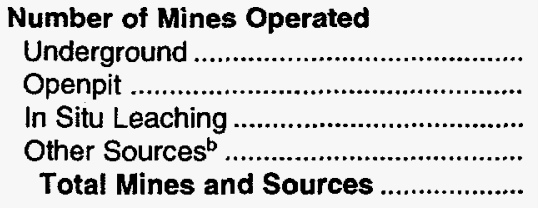 & $\begin{array}{r}13 \\
4 \\
12 \\
2 \\
31\end{array}$ & $\begin{array}{r}19 \\
2 \\
15 \\
1 \\
37\end{array}$ & $\begin{array}{r}17 \\
4 \\
11 \\
0 \\
32\end{array}$ & $\begin{array}{r}19 \\
2 \\
9 \\
2 \\
32\end{array}$ & $\begin{array}{r}27 \\
2 \\
7 \\
3 \\
39\end{array}$ & $\begin{array}{r}6 \\
2 \\
6 \\
1 \\
15\end{array}$ & $\begin{array}{r}4 \\
1 \\
4 \\
8 \\
17\end{array}$ & $\begin{array}{r}0 \\
0 \\
5 \\
7 \\
12\end{array}$ & $\begin{array}{r}0 \\
0 \\
5 \\
7 \\
12\end{array}$ & $\begin{array}{r}0 \\
0 \\
5 \\
7 \\
12\end{array}$ \\
\hline
\end{tabular}

aFor 1986 through 1989, "Other" includes production from openpit, in situ leach, heap leach, mine water, and water-treatment plant solutions. Production quantities were rounded to the nearest 100 thousand pounds. For 1990 and 1991, "Other" includes production from underground, in situ leach, heap leach (1990), mine water, water treatment plant solutions (1990), and restoration. For 1992, "Other" includes production from underground, openpit, and in situ leach mines and uranium bearing water from mine workings, tailings ponds, and restoration. For 1993, the "Other" includes production from in situ leach mines and uranium bearing water from mine workings and restoration. For 1994 and 1995, "Other" includes production from uranium bearing water from mine workings and restoration.

Other Sources includes, in various years, heap leach, mine water, mill site cleanup and mill tailings, well field restoration, and low-grade stockpiles as sources of uranium.

W=Data withheld to avoid disclosure. The data are included in the total for "Other."

Notes: Totals may not equal sum of components because of independent rounding. Table does not include byproduct production and sources.

Sources: Energy Information Administration: 1986-1994-Uranium Industry Annnual 1994 (July 1995); 1995-Form ElA-858, "Uranium Industry Annual Survey" (1995). 
Table 5. U.S. Uranium Concentrate Processing Operations, 1986-1995

\begin{tabular}{|c|c|c|c|c|c|c|c|c|c|c|}
\hline Processing Operations & 1986 & 1987 & 1988 & 1989 & 1990 & 1991 & 1992 & 1993 & 1994 & 1995 \\
\hline Ore Fed to Process ${ }^{a}$ (thousand tons) ....... & 1,308 & 1,441 & 1,214 & 1,235 & 722 & 639 & 256 & 0 & 0 & 167 \\
\hline 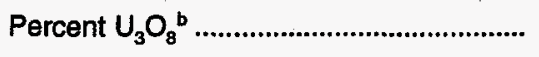 & 0.336 & 0.284 & 0.288 & 0.323 & 0.293 & 0.198 & 0.229 & $-\cdot$ & - & 0.520 \\
\hline \multicolumn{11}{|l|}{ Contained $\mathrm{U}_{3} \mathrm{O}_{8}$ (thousand pounds) } \\
\hline $\begin{array}{l}\text { In Ore } \\
\text { Other Feed Materials }\end{array}$ & $\begin{array}{r}8,783 \\
260\end{array}$ & $\begin{array}{r}8,191 \\
474\end{array}$ & $\begin{array}{r}6,998 \\
507\end{array}$ & $\begin{array}{r}7,977 \\
429\end{array}$ & $\begin{array}{r}4,227 \\
485\end{array}$ & $\begin{array}{r}2,529 \\
179\end{array}$ & $\begin{array}{r}1,171 \\
181\end{array}$ & $\begin{array}{r}0 \\
42\end{array}$ & $\begin{array}{r}0 \\
78\end{array}$ & $\begin{array}{r}1,739 \\
163\end{array}$ \\
\hline Total Mill Feed (thousand pounds $\mathrm{U}_{3} \mathrm{O}_{8}$ ) & 9,043 & 8,664 & 7,505 & 8,406 & 4,712 & 2,708 & 1,353 & 42 & 78 & 1,902 \\
\hline $\begin{array}{l}\text { In-Process Inventory Change } \\
\text { (thousand pounds } \mathrm{U}_{3} \mathrm{O}_{8} \text { ) }\end{array}$ & -64 & -210 & 136 & -234 & -244 & -122 & -25 & 10 & 24 & 157 \\
\hline \multicolumn{11}{|l|}{$\begin{array}{l}\text { Concentrate Produced at Mills } \\
\text { (thousand pounds } \mathrm{U}_{3} \mathrm{O}_{8} \text { ) }\end{array}$} \\
\hline 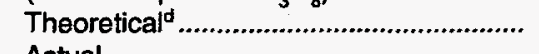 & 9,107 & 8,874 & 7,369 & 8,640 & 4,956 & 2,830 & 1,377 & 31 & 54 & 1,744 \\
\hline Actual & 8,853 & 8,536 & 7,034 & 8,175 & 4,649 & 2,608 & 1,359 & 30 & 46 & 1,615 \\
\hline Recovery as Percent of Total Mill Feed ... & 97.2 & 96.2 & 95.5 & 94.6 & 93.8 & 92.2 & 98.7 & -- & -- & 92.6 \\
\hline $\begin{array}{l}\text { Tailings and Unaccountable. } \\
\text { (thousand pounds } \mathrm{U}_{3} \mathrm{O}_{8} \text { ) }\end{array}$ & 254 & 338 & 335 & 465 & 307 & 222 & 18 & 1 & 8 & 130 \\
\hline \multicolumn{11}{|l|}{ Other Processing } \\
\hline $\begin{array}{l}\text { Total Uranium Concentrate Production } \\
\text { (thousand pounds } \mathrm{U}_{3} \mathrm{O}_{8} \text { ) }\end{array}$ & 13,506 & 12,991 & 13,130 & 13,837 & 8,886 & 7,952 & 5,645 & 3,063 & 3,352 & 6,043 \\
\hline \multicolumn{11}{|l|}{$\begin{array}{l}\text { Total Concentrate Shipped From Mills } \\
\text { and Plants }\end{array}$} \\
\hline 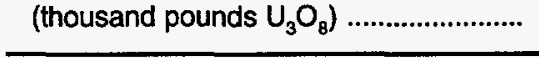 & 10,641 & 11,558 & 12,791 & 14,808 & 12,957 & 8,437 & 6,853 & $\mathbf{3 , 3 7 4}$ & 6,319 & 5,500 \\
\hline
\end{tabular}

"Uranium ore "fed to process" in any year can include: ore mined and shipped to a mill during the same year, ore that was mined during a prior year and later shipped from mine-site stockpiles, and/or ore obtained from drawdowns of stockpiles maintained at a mill site.

Weighted average percent $\mathrm{U}_{3} \mathrm{O}_{8}$ per ton of ore.

Includes for various years uranium from low-grade ore, mill cleanup, mine water, tailings water, and heap leaching, except as footnoted below.

At 100-percent recovery.

$\cdot \mathrm{U}_{3} \mathrm{O}_{8}$ concentrate production from in situ leaching and as a byproduct of other processing. The totals for 1986 through 1988 include $\mathrm{U}_{3} \mathrm{O}_{8}$ recovered from reclamation and mine water at some mills that did not report processing of uranium ore for those years.

Total does not include uranium concentrate production from pilot projects or other research project sources.

$-=$ Not applicable.

Note: Totals may not equal sum of components because of independent rounding.

Sources: Energy Information Administration: 1986-1994-Uranium Industry Annnual 1994 (July 1995); 1995-Form ElA-858, "Uranium Industry Annual Survey" (1995). 
Table 6. Operating Status of Conventional Uranium Mills, End of the Year, 1992-1995

\begin{tabular}{|c|c|c|c|c|c|c|}
\hline \multirow[b]{2}{*}{ Mill Owner } & \multirow[b]{2}{*}{ Name and State } & \multirow{2}{*}{$\begin{array}{c}\text { Milling Capacity } \\
\text { (short tons of ore } \\
\text { per day) }\end{array}$} & \multicolumn{4}{|c|}{ Operating Status at End of the Year } \\
\hline & & & 1992 & 1993 & 1994 & 1995 \\
\hline 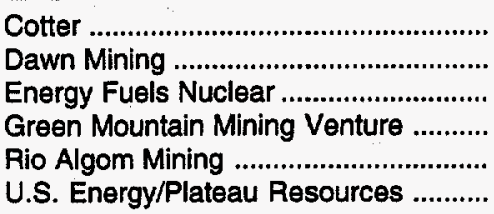 & $\begin{array}{c}\text { Canon City (CO) } \\
\text { Ford (WA) } \\
\text { White Mesa (UT) } \\
\text { Sweetwater (WY) } \\
\text { Ambrosia Lake (NM) } \\
\text { Shootaring (UT) }\end{array}$ & $\begin{array}{r}1,200 \\
450 \\
2,000 \\
3,000 \\
7,000 \\
\text { b750 }\end{array}$ & $\begin{array}{l}1 \\
1 \\
1 \\
1 \\
1\end{array}$ & $\begin{array}{l}1 \\
1 \\
1 \\
1 \\
1 \\
1\end{array}$ & $\begin{array}{l}1 \\
1 \\
1 \\
1 \\
1 \\
1\end{array}$ & $\begin{array}{l}1 \\
1 \\
0 \\
1 \\
1 \\
1\end{array}$ \\
\hline
\end{tabular}

Summary of Mill Status

Number of Mills

Operating ${ }^{c}$...

Inactive

Total .

\section{Available Milling Capacity}

Operating (tons of ore per day)

Inactive (tons of ore per day)

Total Available Capacity

(tons of ore per day)

Average Daily Mill Feed

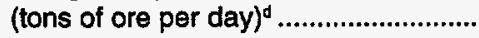

Percent of Total Available Capacity ${ }^{\circ} . .$.

$\begin{array}{lll}- & - & 0 \\ - & -- & 6 \\ -- & - & 6\end{array}$

$\begin{array}{lll}0 & 0 & 1 \\ 6 & 6 & 5 \\ 6 & 6 & 6\end{array}$

\begin{tabular}{rrrrrr}
-- & - & 0 & 0 & 0 & 2,000 \\
-- & -- & 14,650 & 14,650 & 14,650 & 12,400 \\
-- & & & & & \\
& -- & 14,650 & 14,650 & 14,650 & 14,400 \\
- & - & 730 & 0 & 0 & 476 \\
-- & -- & 5 & 0 & 0 & 3 \\
\hline
\end{tabular}

aMilling capacity based on historical data and data reported on Form EIA-858 for 1995

'For 1992 through 1994, Shootaring's capacity was 1,000 short tons of ore per day.

'Number of mills being operated to process uranium at the end of year.

¿Rounded value. Based on 350 workdays per year and total ore fed to process during the year shown in Table 5.

'Rounded value. Calculated based on ore fed to process (Table 5) during 350 workdays per year.

$O=O p e r a t i n g$ at the end of the year, $I=$ Inactive at the end of the year.

-.=Not applicable.

Sources: Energy Information Administration: 1992-1994-Uranium Industry Annual 1994 (July 1995). 1995-Form ElA-858, "Uranium Industry Annual Survey" (1995).

Table 7. Operating Status of Nonconventional Uranium Plants, 1995

\begin{tabular}{|c|c|c|c|c|}
\hline Plant Owner & Name and State & Plant Type & $\begin{array}{c}\text { Rated Capacity" } \\
\text { (thousand pounds } \\
\mathrm{U}_{3} \mathrm{O}_{8} \text { per year) }\end{array}$ & $\begin{array}{c}\text { Operating Status } \\
\text { at the End of } \\
\text { the Year }\end{array}$ \\
\hline Converse County Mining Venture .... & Highland (WY) & In Situ Leach & 2,000 & 0 \\
\hline COGEMA Mining, Inc. ....................... & West Cole (TX) & In Situ Leach & 200 & 1 \\
\hline Crow Butte Resources ....................... & Crow Butte (NE) & In Situ Leach & 1,000 & 0 \\
\hline 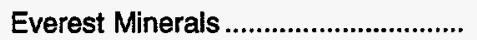 & Hobson (TX) & In Situ Leach & 1,000 & 1 \\
\hline IMC-Agrico Company ........................... & Sunshine Bridge (LA) & Phosphate Byproduct & 420 & 0 \\
\hline IMC-Agrico Company ............................ & Uncle Sam (LA) & Phosphate Byproduct & 750 & 0 \\
\hline IMC-Agrico Company .......................... & Plant City (FL) & Phosphate Byproduct & 608 & 1 \\
\hline IMC-Agrico Company ........................... & New Wales (FL) & Phosphate Byproduct & 750 & i \\
\hline Malapai Resources ............................... & Christensen Ranch (WY) & In Situ Leach & 650 & 0 \\
\hline 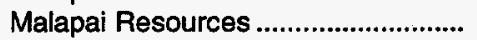 & Holiday-El Mesquite (TX) & In Situ Leach & 600 & 0 \\
\hline 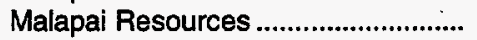 & Irigaray $(W Y)$ & In Situ Leach & 350 & i \\
\hline 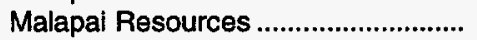 & O'Hern (TX) & In Situ Leach & 0 & $i$ \\
\hline Rio Algom Mining Company ............... & Smith Ranch (WY) & In Situ Leach & 250 & i \\
\hline Uranium Resources, Inc........................ & Kingsville Dome (TX) & In Situ Leach & 1,300 & $i$ \\
\hline Uranium Resources, Inc. ..................... & Rosita (TX) & In Situ Leach & 1,000 & 0 \\
\hline
\end{tabular}

aMilling capacity based on data reported on Form EIA-858 for 1995.

${ }^{\circ} \mathrm{O}=$ Operating at the end of the year; I=Inactive at the end of the year.

'Malapai Resources did not report a rated capacity for the O'Hern plant.

Note: Pathfinder Mines, Inc. has been granted a commercial license for its North Butte-Ruth in situ leach project in Campbell County, Wyoming

Source: Energy Information Administration, Form ElA-858, "Uranium Industry Annual Survey" (1995). 
Table 8. Employment in the U.S. Uranium Industry by Category, 1986-1995 (Person-Years)

\begin{tabular}{|c|c|c|c|c|c|c|}
\hline \multirow[b]{2}{*}{ Year } & \multicolumn{5}{|c|}{ Employment Categories } & \multirow[b]{2}{*}{ Total } \\
\hline & Exploration & Mining & Milling & Processing & Reclamation ${ }^{\mathrm{a}}$ & \\
\hline $1986 \ldots . .$. & 162 & 954 & 513 & 490 & NA & 2,120 \\
\hline $1987 \ldots .$. & 183 & 819 & 432 & 568 & NA & 2,002 \\
\hline $1988 \ldots . .$. & 144 & 849 & 572 & 576 & NA & 2,141 \\
\hline $1989 \ldots .$. & 86 & 659 & 367 & 471 & NA & 1,583 \\
\hline $1990 \ldots .$. & 73 & 664 & 304 & 293 & NA & 1,335 \\
\hline $1991 \ldots .$. & 52 & 411 & 191 & 361 & NA & 1,016 \\
\hline $1992 \ldots .$. & 51 & 219 & 129 & 283 & NA & 682 \\
\hline $1993 \ldots$. & 36 & 133 & 65 & 145 & 491 & 871 \\
\hline $1994 \ldots . .$. & 41 & 157 & 105 & 149 & 528 & 980 \\
\hline $1995 \ldots .$. & 27 & 226 & 121 & 161 & 573 & 1,107 \\
\hline
\end{tabular}

ata on reclamation employment was not collected prior to 1993.

$N A=$ Not available.

Note: Totals may not equal sum of components because of independent rounding.

Sources: Energy Information Administration: 1986-1994-Uranium Industry Annual 1994 (July 1995); 1995-Form EIA-858, "Uranium Industry Annual Survey" (1995).

Table 9. Employment in the U.S. Uranium Industry by State, 1995 (Person-Years)

\begin{tabular}{|c|c|c|}
\hline State(s) & Total & Percent of Total \\
\hline 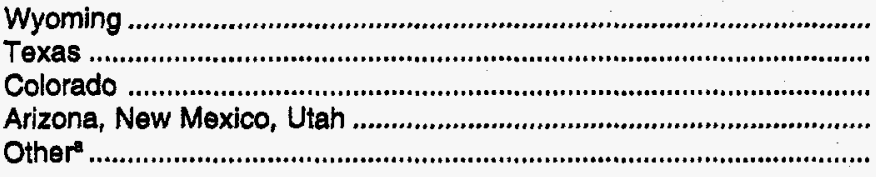 & $\begin{array}{l}350 \\
253 \\
116 \\
233 \\
155\end{array}$ & $\begin{array}{l}32 \\
23 \\
10 \\
21 \\
14\end{array}$ \\
\hline 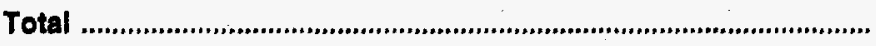 & 1,107 & 100 \\
\hline
\end{tabular}

Includes Florida, Louisiana, Nevada, Washington.

Notes: Totals may not equal sum of components because of independent rounding. Total employment includes 573 person years for reciamation. Source: Energy Information Administration, Form ElA-858, "Uranium Industry Annual Survey" (1995). 


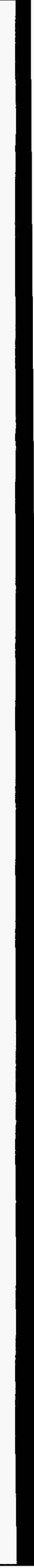




\section{Uranium Marketing Activities in the United States}

\section{Introduction}

Movement of both natural and enriched uranium materials illustrates, for 1995, the normal market mechanisms used by U.S. suppliers and utilities to procure and dispose of uranium (Figure 5). The uranium quantities throughout this chapter are expressed as $\mathrm{U}_{3} \mathrm{O}_{8}$ equivalent $\left(\mathrm{U}_{3} \mathrm{O}_{8} \mathrm{e}\right)$. U.S. utilities acquire uranium each year both from domestic suppliers (domestic purchases) and foreign suppliers (foreign purchases).

Domestic suppliers are U.S.-based firms that exchange, loan, purchase, or sell uranium, and are not domestic electric utilities. They can include uranium brokers, converters, enrichers, fabricators, traders, producers, and uranium property holders. Foreign suppliers and foreign utilities are non-U.S. based firms that market uranium into and from the United States.

Uranium market activities of domestic utilities include purchases from both domestic and foreign suppliers of uranium from domestic and foreign sources, contracting for future supplies, and anticipated uranium requirements of U.S. utilities. In addition, this chapter also presents enrichment activities, the amount of uranium loaded into reactors, total levels of imports and exports, purchases by U.S. brokers and traders, and the year-end 1995 status of uranium inventories in the United States.

\section{Uranium Market Activity of U.S. Utilities}

\section{Uranium Purchases}

In 1995 , U.S. utilities received 43.4 million pounds $\mathrm{U}_{3} \mathrm{O}_{8} \mathrm{e}$, and the average price was $\$ 11.25$ per pound (Table 10). Compared with 1994, the quantity is an increase of 13 percent (Figure 6). Foreign-origin uranium accounted for 38.2 million pounds ( 88 percent) of the deliveries at an average price of $\$ 10.84$ per pound (Table 11). Approximately 40 percent of all uranium received by U.S. utilities was Canadian origin (Table 12). In rank order, the next four country origins were Russia (13 percent), United States (12 percent), Australia (10 percent), and Uzbekistan ( 9 percent) (Figure 7).
The utilities purchased uranium of several material types (Table 13). Uranium concentrate $\left(\mathrm{U}_{3} \mathrm{O}_{8}\right)$ accounted for 85 percent of the purchases, uranium hexafluoride $\left(\mathrm{UF}_{6}\right)$ was 13 percent, and enriched uranium was 2 percent (Figure 8).

Purchases of uranium (both U.S. and foreign-origin) from domestic suppliers by domestic utilities in 1995 totaled 22.3 million pounds $\mathrm{U}_{3} \mathrm{O}_{8} \mathrm{e}, 0.4$ million pounds less than the deliveries for 1994 (Table 14). The average price of these domestic purchases in 1995 was $\$ 11.11$ per pound.

Purchases of uranium (only foreign-origin) from foreign suppliers by U.S. utilities in 1995 totaled 21.1 million pounds $\mathrm{U}_{3} \mathrm{O}_{8} \mathrm{e}, 5.6$ million pounds more than the deliveries for 1994. The average price of these foreign purchases in 1995 was $\$ 11.39$ per pound.

\section{Uranium Price Distributions and Contract Types}

A pricing mechanism was reported for each price of a uranium delivery. One mechanism, contract-specified, was dominant for deliveries in 1995 , whereas, the market-related with no floor pricing mechanism was prevalent in 1994 (Table 14).

While average prices of uranium had risen by 8 percent from its 1994 level of $\$ 10.40$ per pound to $\$ 11.25$ per pound in 1995, the range of prices from highest to lowest was more narrow in 1995 (Table 15).

During 1995, 67 percent of the deliveries to utilities involved purchases under spot and long-term arrangements. The average price for spot purchases was $\$ 10.30$ per pound, and for long-term purchases was $\$ 12.57$ per pound (Table 16).

\section{New Uranium Purchases}

The quantity of uranium delivered in 1995 under 63 new purchase contracts was 15.6 million pounds $\mathrm{U}_{3} \mathrm{O}_{8} \mathrm{e}$, and the average price was $\$ 10.37$ per pound (Table 17). Of this quantity, 51 new spot contracts accounted for 12.4 million pounds in 1995. 
Future deliveries reported for 1996 through 2005, for contracts signed in 1995 , total 39.8 million pounds. Of this quantity, firm deliveries amount to 33.2 million pounds (Table 18).

\section{Anticipated Uranium Market Requirements}

Future deliveries for 1996-2005, based on contracts reported in effect at the end of 1995, for all purchase contracts consisted of 123.7 million pounds for firm deliveries and 47.0 million pounds for optional deliveries (Table 19). Foreign suppliers have contracts for 57 percent of the existing firm deliveries to utilities through 2005.

At the end of 1995, cumulative unfilled uranium requirements for commercial nuclear reactors for 1996 through 2005 were reported to be 314.0 million pounds $\mathrm{U}_{3} \mathrm{O}_{8} \mathrm{e}$ (Table 20). The quantity of firm and optional deliveries of uranium for the same period under existing purchase contracts totaled 170.7 million pounds (Table 21). The contracted deliveries and unfilled requirements combined represent the U.S. utilities anticipated market requirements of uranium (Figure 9). The total ten-year requirements of U.S. utilities, at the end of 1995 , was 484.7 million pounds.

Unfilled requirements category, as reported at the end of 1995, constitute a small portion of anticipated market requirements in 1996 . However, it increases to 55 percent of total anticipated requirements by 1999 and to 95 percent by 2005. For the years 1996 through 1998 it would appear that utilities meet a portion of their enrichment feed deliveries by drawing down uranium inventories (Figure 9). However, for 1999 through 2005, the utilities' enrichment feed deliveries are less than their anticipated market requirements, indicating perhaps a period of uranium inventory build-up or an increase in purchases of enriched uranium product by the U.S. utilities (Table 21).

\section{Uranium Enrichment Activities}

\section{Uranium Feed for Enrichment}

In 1995 , U.S. utilities delivered 44.3 million pounds $\mathrm{U}_{3} \mathrm{O}_{8} \mathrm{e}$ of natural uranium feed to domestic and foreign enrichment suppliers (Table 22). U.S.-origin uranium accounted for 9.2 million pounds ( 21 percent) of the feed deliveries (Table 23). Of the 44.3 million pounds, 77 percent was delivered to the United States Enrichment Corporation (USEC) enrichment plants.

A total of 10.4 million pounds of uranium feed was delivered to foreign enrichment plants in 1995 (Figure 10). Enrichment feed deliveries to foreign enrichment plants was 23 percent of total feed deliveries in 1995 , compared with 11 percent in 1994.

At the end of 1995, the U.S. utilities reported that the amount of natural uranium feed to be shipped for enrichment for the years 1996 through 2005 will vary between 30 million and 53 million pounds annually (Table 24). The total 10-year quantity of natural uranium that utilities expect to send for enrichment is reported at the end of 1995 to be 12.4 million pounds higher than the quantity reported at the end of 1994 for the same period.

\section{Purchases of Enrichment Services}

In 1995, 9.5 million separative work units (SWU) were purchased by U.S. utilities under enrichment services contracts (Table 25.) USEC provided 71 percent of the utilities' SWU and foreign enrichers the remaining 29 percent. In comparison in 1994, U.S. enrichment plants provided 82 percent of the utilities' enrichment needs.

The long-term enrichment service contracts were dominant in 1995, and represented 84 percent of total contracts and were provided at both U.S. and foreign enrichment plants (Table 26). In contrast, uranium enrichment under spot contracts represents only 4 percent of total contracts and was only provided at foreign enrichment plants.

\section{Fuel Assemblies}

The total amount of uranium contained in fuel assemblies loaded into U.S. commercial nuclear reactors during 1995 was 51.1 million pounds $\mathrm{U}_{3} \mathrm{O}_{8} \mathrm{e}$ (Table 27). This was 10.7 million pounds more than in 1994 (Figure 11). These quantities do not include uranium in fuel assemblies removed from reactors that may be reloaded later.

\section{Imports}

In $1995,41.3$ million pounds $\mathrm{U}_{3} \mathrm{O}_{8} \mathrm{e}$ was delivered to U.S. suppliers and U.S. utilities from foreign suppliers in 1995 (Table 28). The average price for the foreign purchases was $\$ 10.20$ per pound $\mathrm{U}_{3} \mathrm{O}_{8} \mathrm{e}$. This is 14 percent higher than the 1994 average import price of $\$ 8.95$ per pound. 


\section{Purchases by U.S. Brokers and Traders}

In 1995, U.S. brokers and traders received 22.9 million pounds $\mathrm{U}_{3} \mathrm{O}_{8} \mathrm{e}$ of uranium at an average price of $\$ 9.53$ per pound (Table 29). Brokers and traders received 3.4 million pounds of U:S.-origin uranium and 19.6 million pounds of foreign origin. Most of the uranium (18.3 million pounds or 80 percent) was from foreign suppliers. In 1994, by comparison, U.S. brokers and traders received 30.8 million pounds $\mathrm{U}_{3} \mathrm{O}_{8}$ e at an average price of $\$ 8.29$ per pound.

\section{Exports}

In 1995, uranium deliveries exported to foreign suppliers and foreign utilities was 9.8 million pounds $\mathrm{U}_{3} \mathrm{O}_{8} \mathrm{e}$, 45 percent less than in 1994, and the average price was $\$ 13.48$ per pound, 19 percent more than in 1994 (Table 30). Of the exported uranium, 52 percent was foreignorigin and 48 percent was U.S.-origin. U.S. brokers and traders sold 5.5 million pounds at an average export price of $\$ 9.83$ per pound in 1995 .

\section{Uranium Inventories}

Total commercial inventories of all material types, as of December 31, 1995, were 70.1 million pounds $\mathrm{U}_{3} \mathrm{O}_{8} \mathrm{e}$, a decrease of 1.6 .8 million pounds compared with the end of 1994 (Table 31). U.S. utility inventories decreased by 9.2 million pounds or 14 percent (Figure 12). U.S. supplier inventories totaled 13.9 million pounds at the end of 1995, a decrease of 35 percent. The DOE and USEC inventories of uranium totaled 110.8 million pounds at year-end 1995.

Uranium concentrate inventories on hand, in storage, or at conversion plants at the end of 1995 were 34.3 million pounds $\mathrm{U}_{3} \mathrm{O}_{8}$ (Table 32), about the same as at the end of 1994. U.S. producers' concentrate inventories totaled 6.2 million pounds (Table 33). Compared with 1994, producer inventories increased by 11 percent. During 1995, U.S. brokers and traders commercial inventories declined 5.0 million pounds, or 43 percent, to 6.7 million pounds. 
Figure 5. Uranium Marketing Activity During 1995

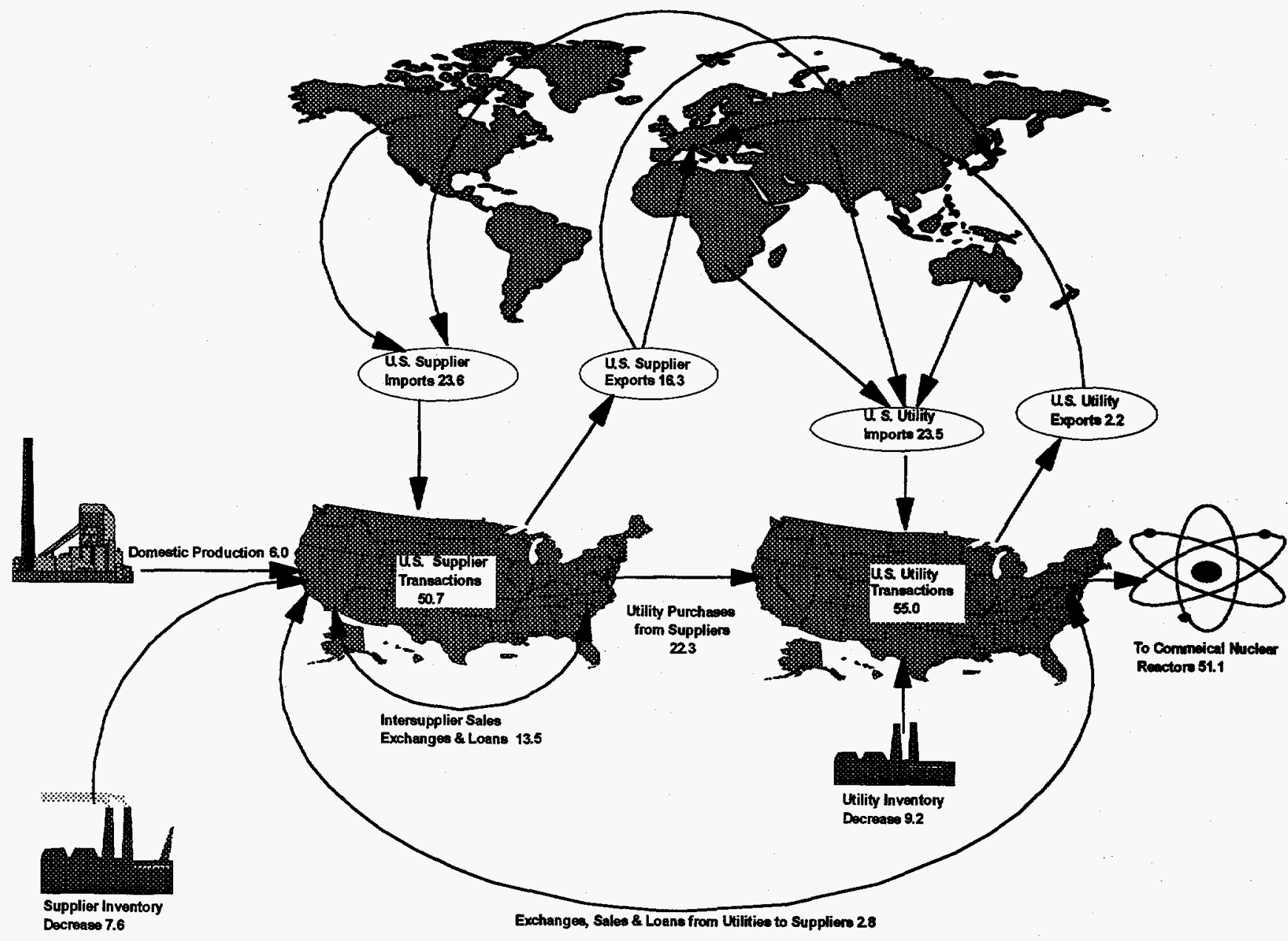

Notes: Quantities are in million pounds $\mathrm{U}_{3} \mathrm{O}_{\mathrm{B}}$ equivalent. Imports and exports include uranium from purchases, sales, and net infiows or outilows from exchanges and loan transactions.

Source: Prepared by the Energy Information Administration, Office of Coal Nuclear, Electric and Alternate Fuels, based on data reported on Form ElA858 for 1995 . 
Figure 6. U.S. Utilities Purchases of Uranium by Origin and Delivery Year, 1994 - 1995

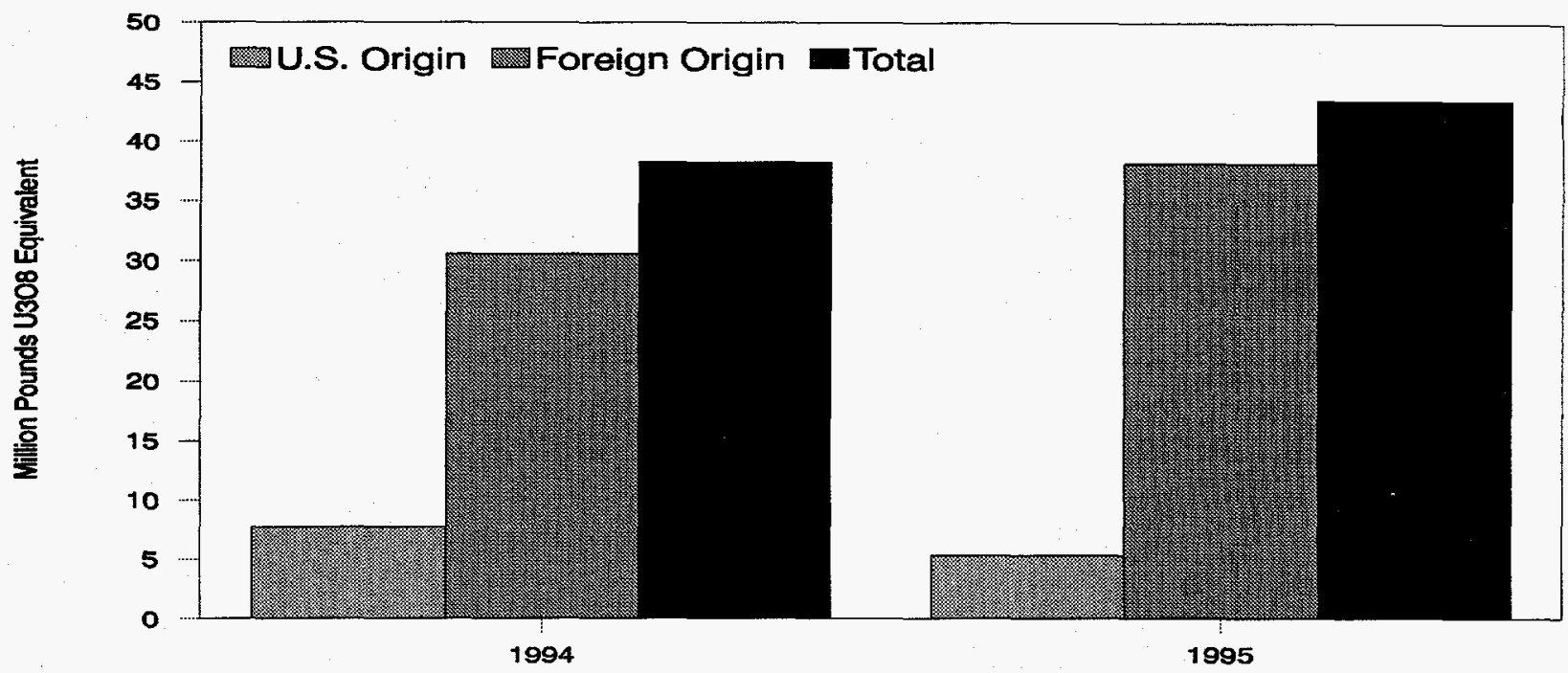

Figure 7. Purchases of Uranium by Selected Country Origin and Delivery Year, 1995

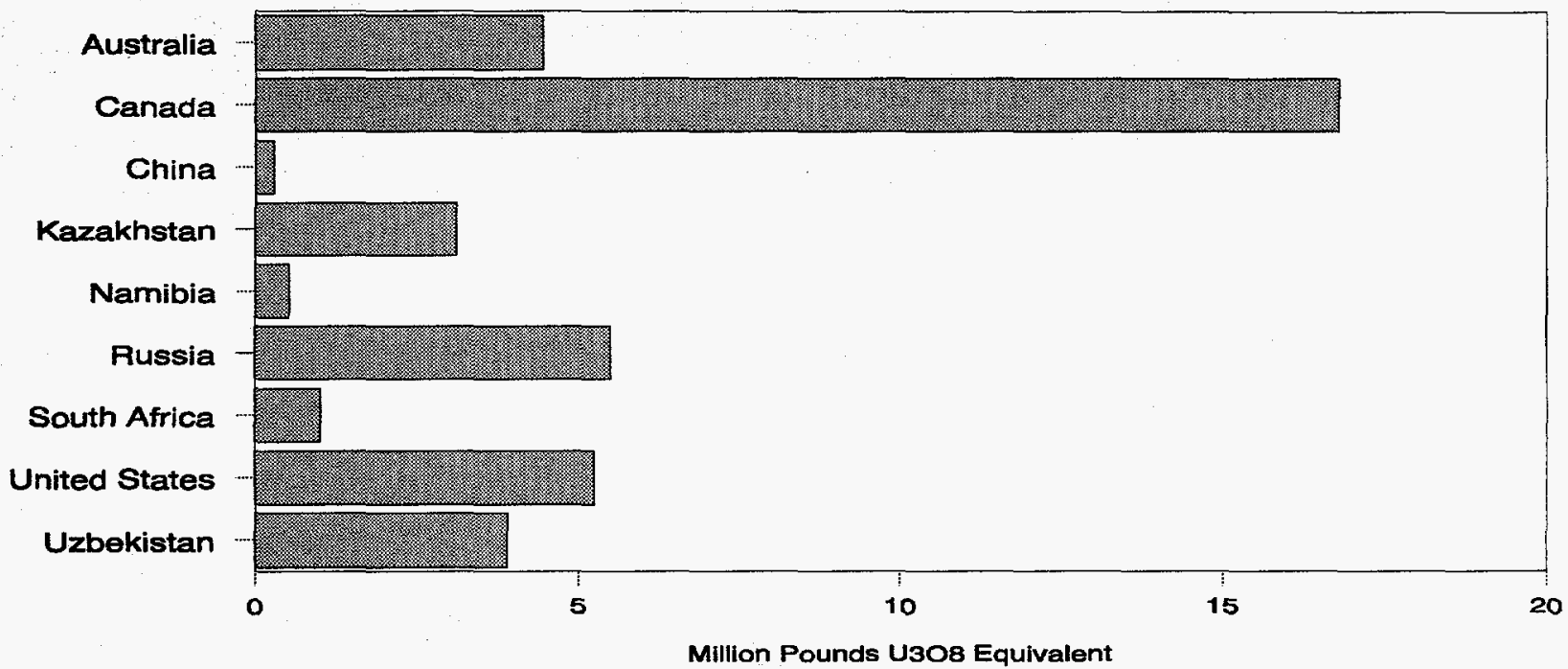

Figure 8. Purchases of Uranium by Material Type and Delivery Year, 1995

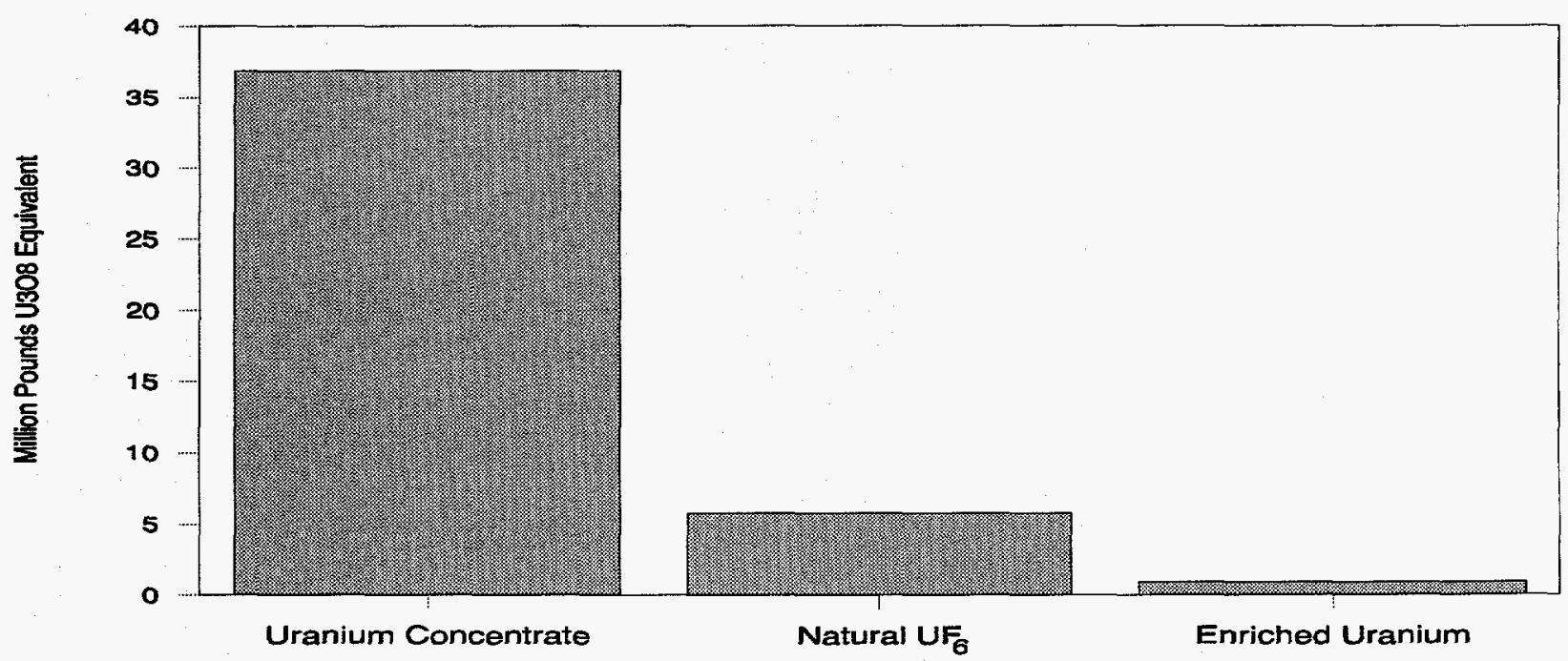

Source: Energy Information Administration, Form EIA-858, "Uranium Industry Annual Survey" (1994-1995). 
Figure 9. Anticipated Uranium Market Requirements of U.S. Utilities, 1996 - 2005

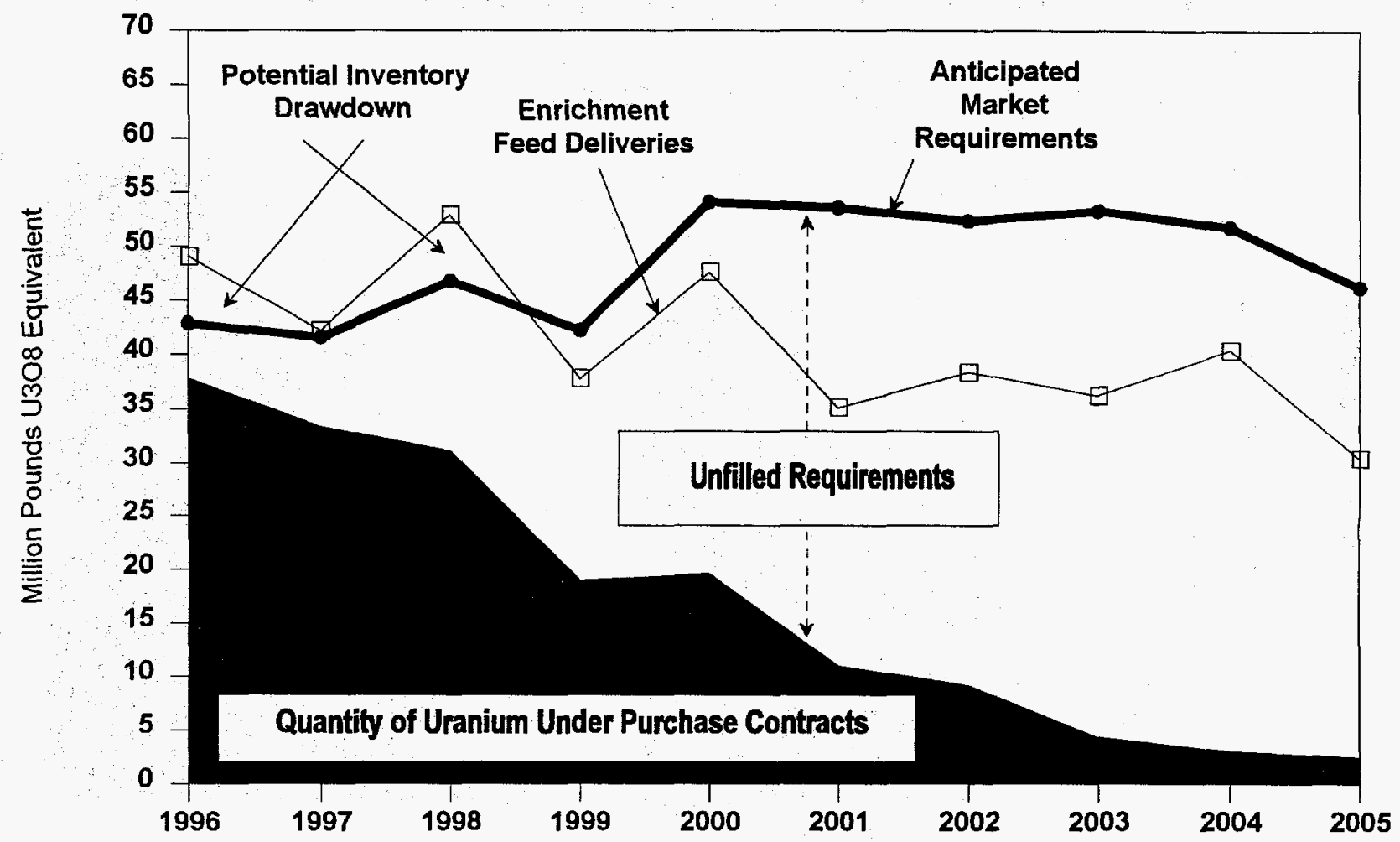

Figure 10. Natural Uranium Feed for Enrichment by Delivery Year, 1994 - 1995

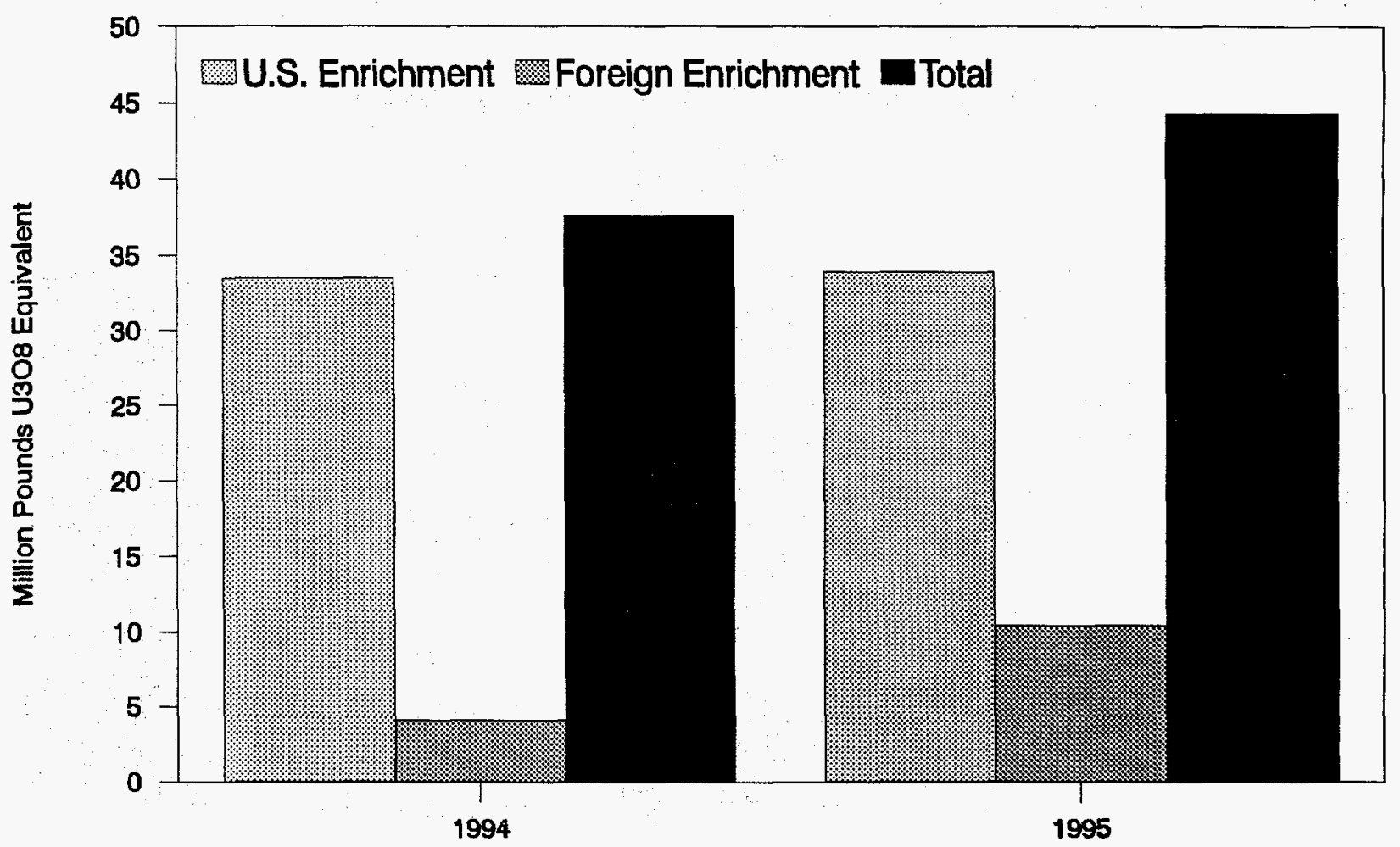

Source: Energy Information Administration, Form EIA-858, "Uranium Industry Annual Survey" (1994-1995). 
Figure 11. Uranium Used in Fuel Assemblies for U.S. Commercial Nuclear Reactors, 1994 - 1995

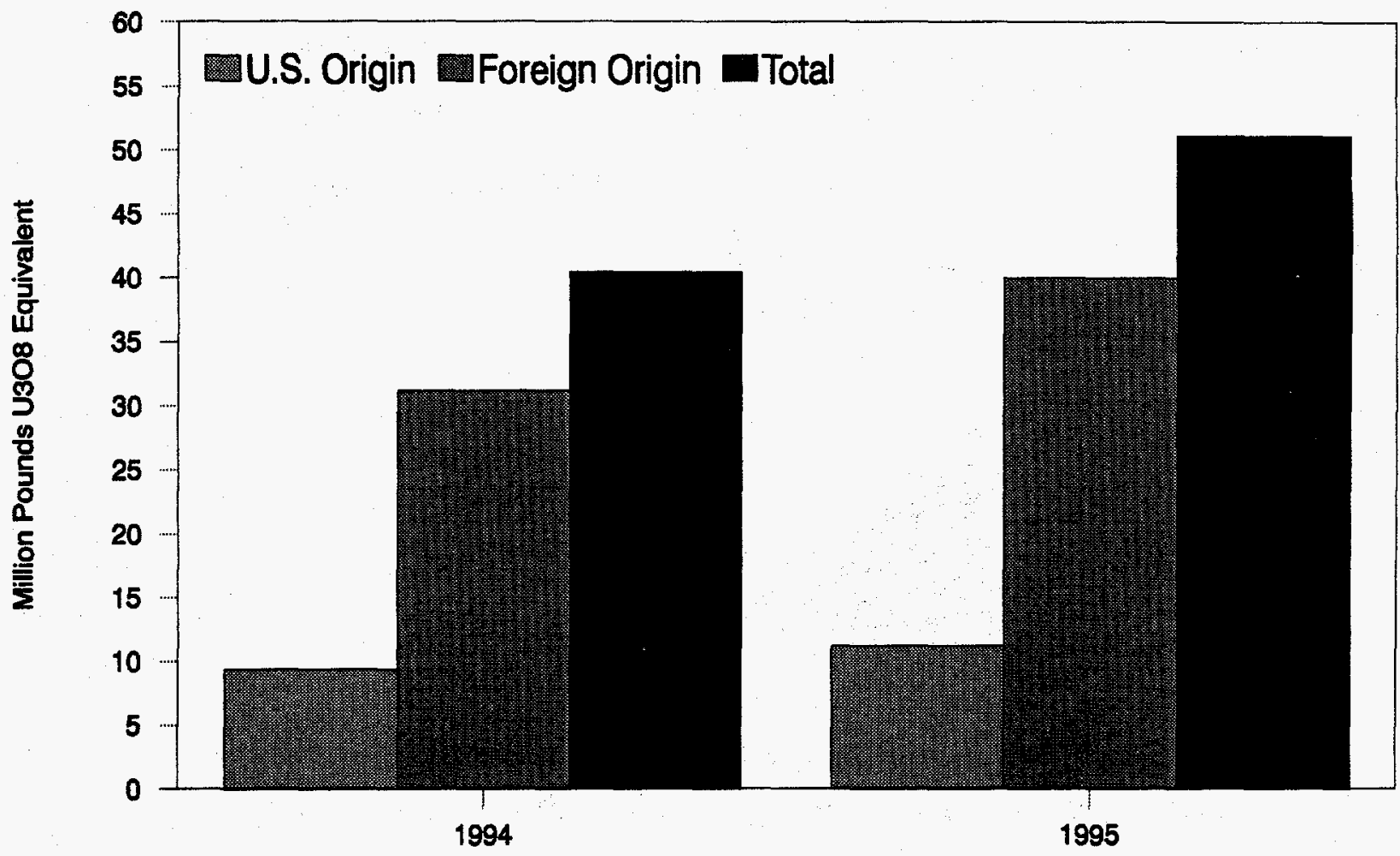

Figure 12. Commerclal Uranium Inventorles at End of the Year, 1994 - 1995

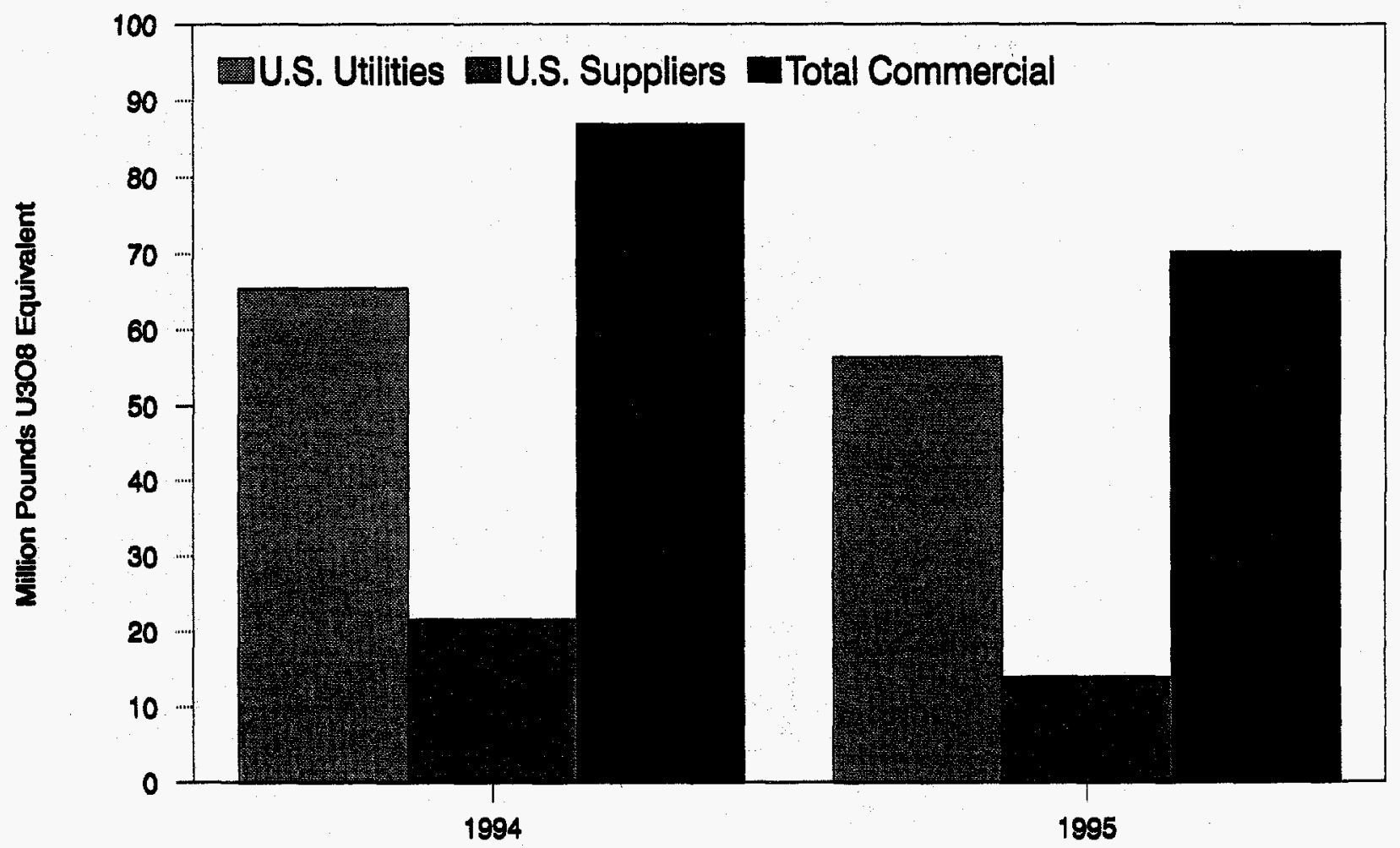

Source: Energy Information Administration, Form EIA-858, "Uranium Industry Annual Survey" (1994-1995). 
Table 10. U.S. Utilities Contracted Uranium by Supplier, Transaction Type, and Delivery Year, 1994-1995

(Thousand Pounds $\mathrm{U}_{3} \mathrm{O}_{8}$ Equivalent; Dollars per Pound $\mathrm{U}_{3} \mathrm{O}_{8}$ Equivalent)

\begin{tabular}{|c|c|c|}
\hline Actual Deliveries & 1994 & 1995 \\
\hline \multicolumn{3}{|l|}{ Received by U.S. Utilities from U.S. Producers: } \\
\hline $\begin{array}{l}\text { Purchases } \\
\text { Welghted-Average Price }\end{array}$ & $\begin{array}{l}5,442 \\
13.72\end{array}$ & $\begin{array}{l}5,289 \\
14.84\end{array}$ \\
\hline \multicolumn{3}{|l|}{ Received by U.S. Utilities from U.S. Brokers and Traders: } \\
\hline $\begin{array}{l}\text { Purchases } \\
\text { Weighted-Average Price }\end{array}$ & $\begin{array}{r}15,284 \\
9.34\end{array}$ & $\begin{array}{r}16,202 \\
9.83\end{array}$ \\
\hline \multicolumn{3}{|l|}{ Received by U.S. Utilities from other U.S. Utilities: } \\
\hline $\begin{array}{l}\text { Purchases } \\
\text { Weighted-Average Price }\end{array}$ & 0 & $\begin{array}{l}0 \\
-\cdot\end{array}$ \\
\hline \multicolumn{3}{|l|}{ Received by U.S. Utilities from other U.S. suppliers: } \\
\hline 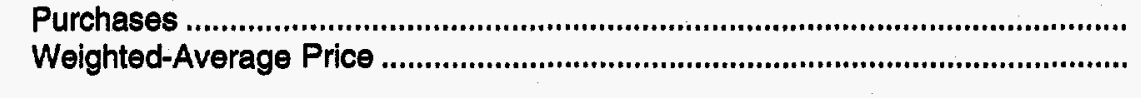 & $\begin{array}{r}1,092 \\
8.04\end{array}$ & $\begin{array}{r}561 \\
12.52\end{array}$ \\
\hline \multicolumn{3}{|l|}{ Received by U.S. Utilities from Foreign Suppllers: } \\
\hline $\begin{array}{l}\text { Purchases } \\
\text { Weighted-Average Price }\end{array}$ & $\begin{array}{r}16,463 \\
10.43\end{array}$ & $\begin{array}{r}21,389 \\
11.40\end{array}$ \\
\hline \multicolumn{3}{|l|}{ Total Received by U.S. Utllities: } \\
\hline 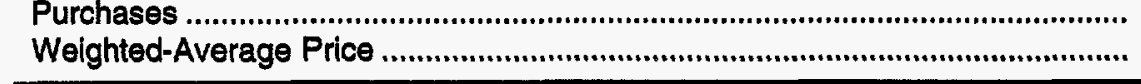 & $\begin{array}{r}38,281 \\
10.40\end{array}$ & $\begin{array}{r}43,441 \\
11.25\end{array}$ \\
\hline
\end{tabular}

$\ldots=$ Not applicable.

Note: "Other U.S. suppliers" are U.S. converters, entchers, and fabricators.

Source: Energy Information Administration, Form ElA-858, "Uranlum Industry Annual Survey" (1994-1995).

Table 11. U.S. Utilities Contracted Uranlum by Transaction Type and Delivery Year, 1994-1995 (Thousand Pounds $\mathrm{U}_{3} \mathrm{O}_{8}$ Equivalent; Dollars per Pound $\mathrm{U}_{3} \mathrm{O}_{8}$ Equivalent)

\begin{tabular}{|c|c|c|}
\hline Actual Deliveries & 1994 & 1995 \\
\hline \multicolumn{3}{|l|}{ Received by U.S. Utilities of U.S.-Origin Uranium: } \\
\hline Peighted-Average Price & $\begin{array}{l}7,718 \\
12.08\end{array}$ & $\begin{array}{l}5,246 \\
14.20\end{array}$ \\
\hline \multicolumn{3}{|l|}{ Received by U.S. Utillties of Foreign-Origin Uranium: } \\
\hline 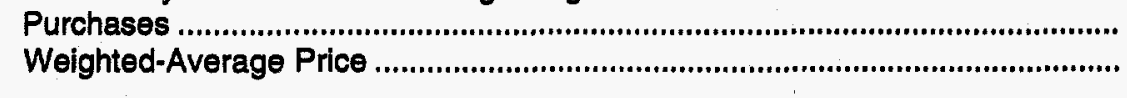 & $\begin{array}{r}30,563 \\
9.97\end{array}$ & $\begin{array}{r}38,195 \\
10.84\end{array}$ \\
\hline $\begin{array}{l}\text { Total: } \\
\text { Purchases } \\
\text { Weighted-Average Price }\end{array}$ & $\begin{array}{r}38,281 \\
10.40\end{array}$ & $\begin{array}{r}43,441 \\
11.25\end{array}$ \\
\hline
\end{tabular}

Source: Energy Information Adminlstration, Form ElA-858, "Uranlum Industry Annual Survey" (1994-1995). 
Table 12. U.S. Utilities Purchases of Uranium by Origin Country and Delivery Year, 1994-1995 (Thousand Pounds $\mathrm{U}_{3} \mathrm{O}_{8}$ Equivalent; Dollars per Pound $\mathrm{U}_{3} \mathrm{O}_{8}$ Equivalent)

\begin{tabular}{|c|c|c|c|c|}
\hline \multirow[b]{2}{*}{ Origin Country } & \multicolumn{2}{|c|}{ Actual Deliveries in 1994} & \multicolumn{2}{|c|}{ Actual Deliveries in 1995} \\
\hline & Purchases & $\begin{array}{c}\text { Weighted- } \\
\text { Average Price }\end{array}$ & Purchases & $\begin{array}{l}\text { Welghted- } \\
\text { Average Price }\end{array}$ \\
\hline 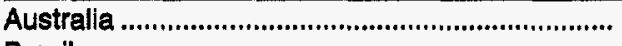 & 2,812 & 9.88 & 4,448 & 10.98 \\
\hline 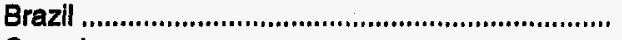 & $W$ & W & 0 & -. \\
\hline 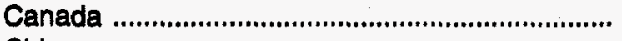 & 14,613 & 10.49 & 16,799 & 11.82 \\
\hline China & 1,696 & 9.56 & 293 & 11.49 \\
\hline France & W & W & $W$ & W \\
\hline Gabon & W & W & W & W \\
\hline 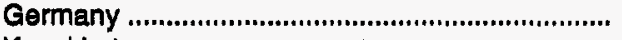 & W & W & $W$ & W \\
\hline 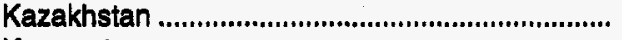 & 2,777 & 8.94 & 3,097 & 8.99 \\
\hline Kyrgyzstan & $W$ & W & W & W \\
\hline 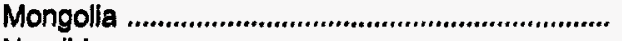 & W & W & W & W \\
\hline Namíbia & 796 & 9.76 & 530 & 9.88 \\
\hline Niger & 0 & -. & W & W \\
\hline 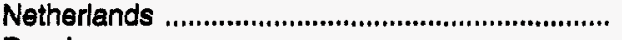 & 0 & -. & $W$ & W \\
\hline Russia & 1,779 & 8.81 & 5,500 & 9.45 \\
\hline South Africa & 1,106 & 9.64 & 1,002 & 12.57 \\
\hline Spain & 0 & -. & W & W \\
\hline Tajikistan & W & W & W & W \\
\hline Ukraine & W & W & W & $W$ \\
\hline 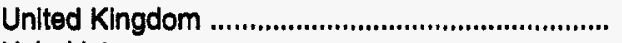 & W & W & W & W \\
\hline Uzbekistan & 3,550 & 8.35 & 3,895 & 8.61 \\
\hline Forelgn Total Quantity .......................................... & 30,563 & 9.97 & 38,195 & 10.84 \\
\hline 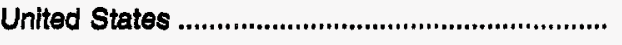 & 7,718 & 12.08 & 5,246 & 14.20 \\
\hline Total Quantlty & 38,281 & 10.40 & 43,441 & 11.25 \\
\hline
\end{tabular}

W=Data withheld to avoid disclosure. $-=$ = Not applicable.

Sources: Energy Information Administration: 1994-Uranium Industry Annual 1994 (July 1995); 1995-Form E|A-858, "Uranium Industry Annual Survey" (1995).

Table 13. U.S. Utilities Contracted Uranium by Transaction Type, Material Type, and Delivery Year, 1995

(Thousand Pounds $\mathrm{U}_{3} \mathrm{O}_{8}$ Equivalent; Dollars per Pound $\mathrm{U}_{3} \mathrm{O}_{8}$ Equivalent)

\begin{tabular}{|c|c|c|c|c|}
\hline Actual Deliveries & $\mathrm{U}_{3} \mathrm{O}_{6}$ & Natural UF & $\begin{array}{l}\text { Enriched } \\
\text { Uranium }\end{array}$ & Total \\
\hline 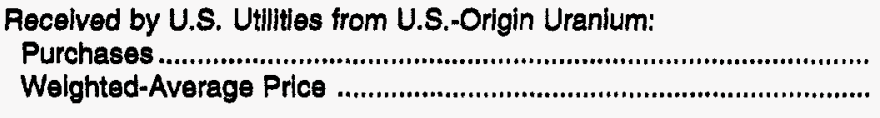 & $\begin{array}{l}4,627 \\
14.63\end{array}$ & $\begin{array}{r}619 \\
11.03\end{array}$ & $\begin{array}{l}0 \\
-.\end{array}$ & $\begin{array}{l}5,246 \\
14.20\end{array}$ \\
\hline 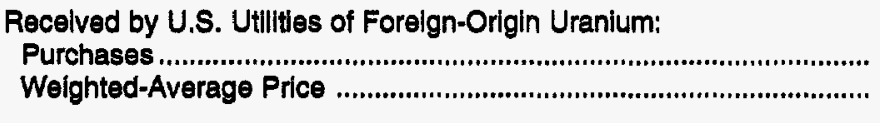 & $\begin{array}{r}32,196 \\
10.84\end{array}$ & $\begin{array}{l}5,134 \\
11.10\end{array}$ & $\begin{array}{r}865 \\
9.29\end{array}$ & $\begin{array}{r}38,195 \\
10.84\end{array}$ \\
\hline 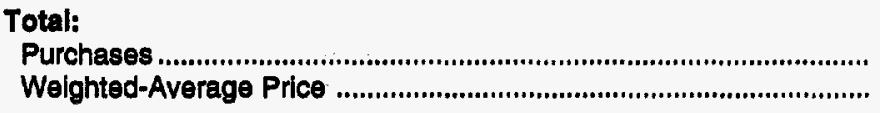 & $\begin{array}{r}36,823 \\
11.32\end{array}$ & $\begin{array}{l}5,753 \\
11.10\end{array}$ & $\begin{array}{r}865 \\
9.29\end{array}$ & $\begin{array}{r}43,441 \\
11.25\end{array}$ \\
\hline
\end{tabular}

. = Not applicable.

Source: Energy Information Administration, Form E|A-858, "Uranium Industry Annual Survey" (1995). 
Table 14. Average Price and Quantity for Purchases of Uranium by U.S. Utilities by Pricing Mechanisms and Delivery Year, 1994-1995

(Dollars per Pound $\mathrm{U}_{3} \mathrm{O}_{8}$ Equivalent; Thousand Pounds $\mathrm{U}_{3} \mathrm{O}_{8}$ Equivalent)

\begin{tabular}{|c|c|c|c|c|c|c|}
\hline \multirow[b]{2}{*}{ Pricing Mechanisms } & \multicolumn{2}{|c|}{ Domestic Purchases } & \multicolumn{2}{|c|}{ Foreign Purchases } & \multicolumn{2}{|c|}{ Total Purchases } \\
\hline & 1994 & 1995 & 1994 & 1995 & 1994 & 1995 \\
\hline 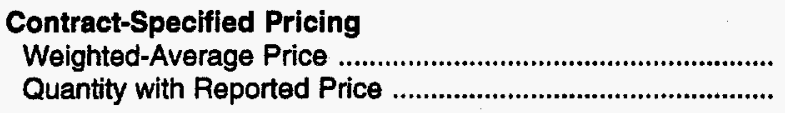 & $\begin{array}{r}10.68 \\
11,154\end{array}$ & $\begin{array}{r}10.58 \\
17,065\end{array}$ & $\begin{array}{l}11.92 \\
2,489\end{array}$ & $\begin{array}{l}12.96 \\
5,584\end{array}$ & $\begin{array}{r}10.90 \\
13,643\end{array}$ & $\begin{array}{r}11.16 \\
22,649\end{array}$ \\
\hline 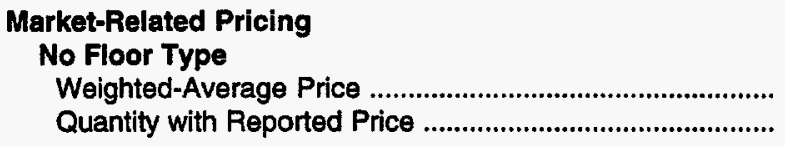 & $\begin{array}{r}9.76 \\
7,083\end{array}$ & $\begin{array}{l}10.19 \\
2,119\end{array}$ & $\begin{array}{r}9.21 \\
8,269\end{array}$ & $\begin{array}{l}10.85 \\
8,278\end{array}$ & $\begin{array}{r}9.46 \\
15,352\end{array}$ & $\begin{array}{r}10.72 \\
10,397\end{array}$ \\
\hline 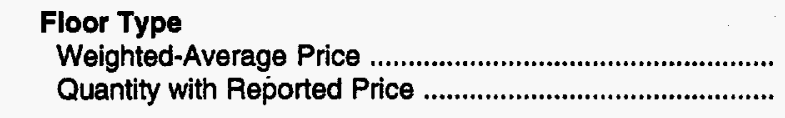 & $\begin{array}{r}20.03 \\
606\end{array}$ & $\begin{array}{r}17.86 \\
683\end{array}$ & $\begin{array}{l}11.80 \\
3,899\end{array}$ & $\begin{array}{l}10.84 \\
4,291\end{array}$ & $\begin{array}{l}12.91 \\
4,505\end{array}$ & $\begin{array}{l}11.81 \\
4,974\end{array}$ \\
\hline 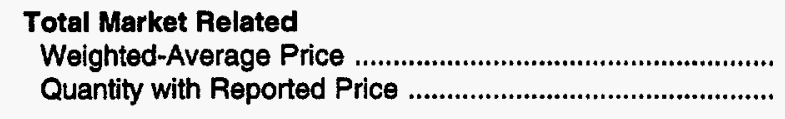 & $\begin{array}{l}10.57 \\
7,689\end{array}$ & $\begin{array}{l}12.05 \\
2,802\end{array}$ & $\begin{array}{r}10.04 \\
12,168\end{array}$ & $\begin{array}{r}10.85 \\
12,569\end{array}$ & $\begin{array}{r}10.24 \\
19,857\end{array}$ & $\begin{array}{r}11.07 \\
15,371\end{array}$ \\
\hline 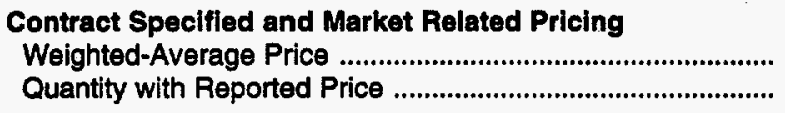 & $\begin{array}{r}10.63 \\
18,843\end{array}$ & $\begin{array}{r}10.79 \\
19,867\end{array}$ & $\begin{array}{r}10.36 \\
14,657\end{array}$ & $\begin{array}{r}11.50 \\
18,153\end{array}$ & $\begin{array}{r}10.51 \\
33,500\end{array}$ & $\begin{array}{r}11.13 \\
38,020\end{array}$ \\
\hline 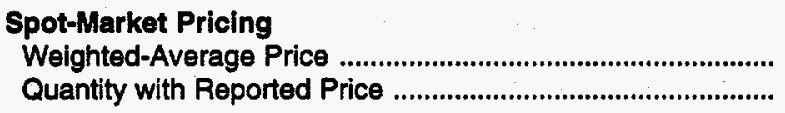 & $\begin{array}{r}9.37 \\
714\end{array}$ & $\begin{array}{r}9.07 \\
748\end{array}$ & $\ddot{0}$ & $\begin{array}{l}10.26 \\
1,706\end{array}$ & $\begin{array}{l}9.37 \\
714\end{array}$ & $\begin{array}{r}9.90 \\
2,454\end{array}$ \\
\hline 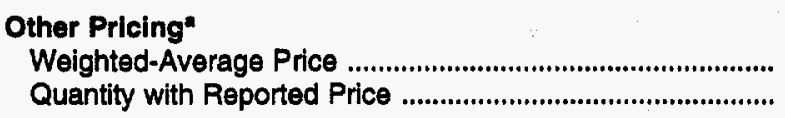 & $\begin{array}{r}8.56 \\
3,188\end{array}$ & $\begin{array}{l}15.87 \\
1,687\end{array}$ & $\begin{array}{r}13.43 \\
879\end{array}$ & $\begin{array}{l}11.34 \\
1,280\end{array}$ & $\begin{array}{r}9.61 \\
4,067\end{array}$ & $\begin{array}{l}13.92 \\
2,967\end{array}$ \\
\hline 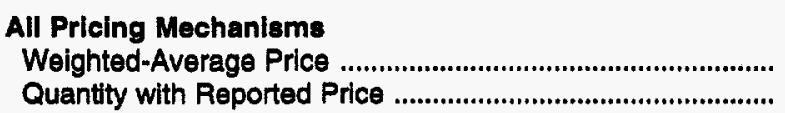 & $\begin{array}{r}10.30 \\
22,745\end{array}$ & $\begin{array}{r}11.11 \\
22,302\end{array}$ & $\begin{array}{r}10.53 \\
15,536\end{array}$ & $\begin{array}{r}11.39 \\
21,139\end{array}$ & $\begin{array}{r}10.40 \\
38,281\end{array}$ & $\begin{array}{r}11.25 \\
43,441\end{array}$ \\
\hline
\end{tabular}

Category used to report pricing mechanisms that are different from the other categories.

-NoNot appilcable

Source: Energy Information Administration, Form ElA-858, "Uranium Industry Annual Survey" (1994-1995). 
Table 15. Price Distributions of Uranium Purchases by U.S. Utilities by Delivery Year, 1994-1995 (Thousand Pounds $\mathrm{U}_{3} \mathrm{O}_{8}$ Equivalent; Dollars per Pound $\mathrm{U}_{3} \mathrm{O}_{8}$ Equivalent)

\begin{tabular}{|c|c|c|c|c|}
\hline \multirow[b]{2}{*}{ Distributions } & \multicolumn{2}{|c|}{ Actual Deliveries in 1994} & \multicolumn{2}{|c|}{ Actual Deliveries in 1995} \\
\hline & $\begin{array}{l}\text { Quantity with } \\
\text { Reported Price }\end{array}$ & $\begin{array}{c}\text { Weighted- } \\
\text { Average Price }\end{array}$ & $\begin{array}{l}\text { Quantity with } \\
\text { Reported Price }\end{array}$ & $\begin{array}{c}\text { Weighted- } \\
\text { Average Price }\end{array}$ \\
\hline \multicolumn{5}{|l|}{ Octile ${ }^{a}:$} \\
\hline $\begin{array}{l}\text { First } \\
\text { Second } \\
\text { Third } \\
\text { Fourth } \\
\text { Fifth } \\
\text { Sixth } \\
\text { Seventh } \\
\text { Eighth }\end{array}$ & $\begin{array}{l}4,785 \\
4,785 \\
4,785 \\
4,785 \\
4,785 \\
4,785 \\
4,785 \\
4,785\end{array}$ & $\begin{array}{r}7.08 \\
8.86 \\
9.13 \\
9.23 \\
9.35 \\
9.54 \\
10.89 \\
19.08\end{array}$ & $\begin{array}{l}5,430 \\
5,430 \\
5,430 \\
5,430 \\
5,430 \\
5,430 \\
5,430 \\
5,430\end{array}$ & $\begin{array}{r}7.50 \\
9.34 \\
9.85 \\
10.40 \\
11.06 \\
11.61 \\
12.17 \\
18.05\end{array}$ \\
\hline 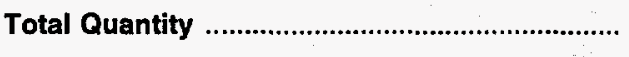 & 38,281 & 10.40 & 43,441 & 11.25 \\
\hline \multicolumn{5}{|l|}{ Quartileb: } \\
\hline $\begin{array}{l}\text { First } \\
\text { Second } \\
\text { Third } \\
\text { Fourth }\end{array}$ & $\begin{array}{r}11,966 \\
9,878 \\
7,828 \\
8,609\end{array}$ & $\begin{array}{r}8.51 \\
9.35 \\
10.29 \\
14.31\end{array}$ & $\begin{array}{r}15,601 \\
13,620 \\
5,037 \\
9,183\end{array}$ & $\begin{array}{r}9.48 \\
10.74 \\
11.69 \\
14.75\end{array}$ \\
\hline Total Quantity & 38,281 & 10.40 & 43,441 & 11.25 \\
\hline
\end{tabular}

actile distribution divides total pounds of uranium delivered (with a price) into eight distributions by price and provides the quantity-weighted average price for each distribution.

'Quartile distribution divides total pounds of uranium delivered (with a price) into four distributions by each utility's aggregate weighted-average price and provides the quantity and average price for each distribution.

Note: Totals may not equal sum of components because of independent rounding.

Sources: Energy Information Administration: 1994-Uranium Industry Annual 1994 (July 1995); 1995-Form ElA-858, "Uranium Industry Annual Survey" (1995).

Table 16. U.S. Utility Uranium Purchases by Contract Type and Material Type, 1995 (Thousand Pounds $\mathrm{U}_{3} \mathrm{O}_{8}$ Equivalent; Dollars per Pound $\mathrm{U}_{3} \mathrm{O}_{8}$ Equivalent)

\begin{tabular}{|c|c|c|c|c|c|c|c|c|c|c|}
\hline \multirow[b]{2}{*}{ Material Type } & \multicolumn{2}{|c|}{ Spot Contracts } & \multicolumn{2}{|c|}{$\begin{array}{l}\text { Short-term } \\
\text { Contracts }\end{array}$} & \multicolumn{2}{|c|}{$\begin{array}{l}\text { Medium-term } \\
\text { Contracts }\end{array}$} & \multicolumn{2}{|c|}{$\begin{array}{l}\text { Long-term } \\
\text { Contracts }\end{array}$} & \multicolumn{2}{|c|}{ Total } \\
\hline & $\begin{array}{c}\text { Quantity } \\
\text { with } \\
\text { Reported } \\
\text { Price }\end{array}$ & $\begin{array}{l}\text { Weighted } \\
\text { Average } \\
\text { Price }\end{array}$ & $\begin{array}{c}\text { Quantity } \\
\text { with } \\
\text { Reported } \\
\text { Price }\end{array}$ & $\begin{array}{l}\text { Weighted } \\
\text { Average } \\
\text { Price }\end{array}$ & $\begin{array}{c}\text { Quantity } \\
\text { with } \\
\text { Reported } \\
\text { Price }\end{array}$ & $\begin{array}{l}\text { Weighted } \\
\text { Average } \\
\text { Price }\end{array}$ & $\begin{array}{l}\text { Quantity } \\
\text { with } \\
\text { Reported } \\
\text { Price }\end{array}$ & $\begin{array}{l}\text { Weighted } \\
\text { Average } \\
\text { Price }\end{array}$ & $\begin{array}{c}\text { Quantity } \\
\text { with } \\
\text { Reported } \\
\text { Price }\end{array}$ & $\begin{array}{l}\text { Weighted } \\
\text { Average } \\
\text { Price }\end{array}$ \\
\hline $\mathrm{U}_{3} \mathrm{O}_{8}$ & 8,968 & 10.13 & 3,808 & 9.17 & 9,731 & 11.14 & 14,316 & 12.75 & 36,823 & 11.32 \\
\hline Natural UF $F_{6}$ & $w$ & $w$ & 0 & - & 724 & 12.88 & W & w & 5,753 & 11.10 \\
\hline Enriched Uranium ........................ & W & $w$ & 0 & -- & 0 & - & $w$ & $w$ & 865 & 9.29 \\
\hline Total Quantity ............................ & 13,601 & 10.30 & 3,808 & 9.17 & 10,455 & 11.26 & 15,577 & 12.57 & 43,441 & 11.25 \\
\hline
\end{tabular}

$W=$ Data withheld to avoid disclosure. $-\cdot=$ Not applicable.

Source: Energy Information Administration, Form ElA-858, "Uranium Industry Annual Survey" (1995). 
Table 17. New Contracts Signed by U.S. Utilities in 1995 by Contract Type and Delivery Year 1995 (Thousand Pounds $\mathrm{U}_{3} \mathrm{O}_{8}$ Equivalent; Dollars per Pound $\mathrm{U}_{3} \mathrm{O}_{8}$ Equivalent)

\begin{tabular}{|c|c|c|c|}
\hline Purchase Contract Type & $\begin{array}{l}\text { Quantity of Actual Deliveries } \\
\text { Received in } 1995\end{array}$ & $\begin{array}{c}\text { Weighted- } \\
\text { Average Price }\end{array}$ & $\begin{array}{c}\text { Number of New } \\
\text { Purchase Contracts }\end{array}$ \\
\hline 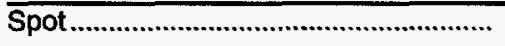 & 12,417 & 10.42 & 51 \\
\hline Short-term & $W$ & W & 1 \\
\hline Medium-term & 2,365 & 10.20 & 10 \\
\hline 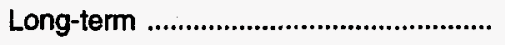 & W & $w$ & 1 \\
\hline Total & 15,573 & 10.37 & 63 \\
\hline
\end{tabular}

$W=$ Data witheld to avoid disclosure.

Source: Energy Information Administration, Form EIA-858, "Uranium Industry Annual Survey" (1995).

Table 18. U.S. Utilities New Contracted Purchases of Uranium by Delivery Year, 1996-2005 (Thousand Pounds $\mathrm{U}_{3} \mathrm{O}_{8}$ Equivalent)

\begin{tabular}{|c|c|c|c|}
\hline Year of Delivery & Firm Deliveries & Optional Deliveries & Total Deliveries \\
\hline 1996 & 6,590 & 520 & 7,110 \\
\hline 1997 & 6,609 & 1,429 & 8,038 \\
\hline 1998 & 6,928 & 1,005 & 7,933 \\
\hline 1999 & 3,123 & 945 & 4,068 \\
\hline 2000 & 4,172 & 1,269 & 5,441 \\
\hline 2001 & 2,117 & 485 & 2,602 \\
\hline 2002 & 2,160 & 895 & 3,055 \\
\hline 2003 & 773 & 0 & 773 \\
\hline 2004 & 677 & 0 & 677 \\
\hline 2005 & 96 & 0 & 96 \\
\hline Total & 33,245 & 6,548 & 39,793 \\
\hline
\end{tabular}

Source: Energy Information Administration, Form ElA-858, "Uranium Industry Annual Survey" (1995). 
Table 19. U.S. Utilities Contracted Purchases of Uranium from Suppliers, in Effect at the End of 1995, by Delivery Year, 1996-2005

(Thousand Pounds $\mathrm{U}_{3} \mathrm{O}_{8}$ Equivalent)

\begin{tabular}{|c|c|c|c|c|c|c|}
\hline \multirow[b]{2}{*}{ Year of Delivery } & \multicolumn{2}{|c|}{$\begin{array}{c}\text { Purchases from U.S. } \\
\text { Suppliers }\end{array}$} & \multicolumn{2}{|c|}{$\begin{array}{c}\text { Purchases from Foreign } \\
\text { Suppliers }\end{array}$} & \multicolumn{2}{|c|}{$\begin{array}{c}\text { Purchases from All } \\
\text { Suppliers }\end{array}$} \\
\hline & $\begin{array}{c}\text { Firm } \\
\text { Deliveries } \\
\end{array}$ & $\begin{array}{l}\text { Optional } \\
\text { Deliveries } \\
\end{array}$ & $\begin{array}{c}\text { Firm } \\
\text { Deliveries }\end{array}$ & $\begin{array}{l}\text { Optional } \\
\text { Deliveries }\end{array}$ & $\begin{array}{c}\text { Firm } \\
\text { Deliveries }\end{array}$ & $\begin{array}{c}\text { Optional } \\
\text { Deliveries }\end{array}$ \\
\hline 1996 & 13,863 & 2,154 & 18,097 & 3,673 & 31,960 & 5,827 \\
\hline 1997 & 11,207 & 3,052 & 14,378 & 4,649 & 25,585 & 7,701 \\
\hline 1998 & 9,096 & 2,607 & 14,575 & 4,793 & 23,671 & 7,400 \\
\hline 1999 & 5,065 & 1,906 & 8,111 & 3,907 & 13,176 & 5,813 \\
\hline 2000 & 5,781 & 1,773 & 9,432 & 2,616 & 15,213 & 4,389 \\
\hline 2001 & 3,426 & 798 & 3,558 & 3,184 & 6,984 & 3,982 \\
\hline 2002 & 3,254 & 1,053 & 1,939 & 2,911 & 5,193 & 3,964 \\
\hline 2003 & 773 & 1,352 & 140 & 2,085 & 913 & 3,437 \\
\hline 2004 & 677 & 752 & 140 & 1,480 & 817 & 2,232 \\
\hline 2005 & 96 & 752 & 140 & 1,480 & 236 & 2,232 \\
\hline 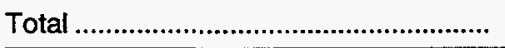 & 53,238 & 16,199 & 70,510 & 30,778 & 123,748 & 46,977 \\
\hline
\end{tabular}

Source: Energy Information Administration, Form ElA-858, "Uranium Industry Annual Survey" (1995).

Table 20. Unfilled Uranium Requirements of U.S. Utilities, 1996-2005 (Thousand Pounds $\mathrm{U}_{3} \mathrm{O}_{8}$ Equivalent)

\begin{tabular}{|c|c|c|c|c|}
\hline \multirow[b]{2}{*}{ Year } & \multicolumn{2}{|c|}{ As of December 31, 1994} & \multicolumn{2}{|c|}{ As of December 31, 1995} \\
\hline & Annual & Cumulative & Annual & Cumulative \\
\hline 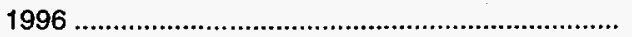 & 12,293 & 12,293 & 5,063 & 5,063 \\
\hline 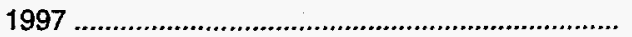 & 17,374 & 29,667 & 8,285 & 13,348 \\
\hline 1998 & 24,816 & 54,483 & 15,709 & 29,057 \\
\hline 1999 & 33,986 & 88,469 & 23,200 & 52,257 \\
\hline 2000 & 30,233 & 118,702 & 34,497 & 86,754 \\
\hline 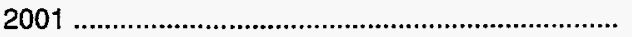 & 44,192 & 162,894 & 42,600 & 129,354 \\
\hline 2002 & 44,950 & 207,844 & 43,184 & 172,538 \\
\hline $2003 \ldots \ldots \ldots \ldots \ldots \ldots \ldots \ldots \ldots$ & 40,958 & 248,802 & 48,955 & 221,493 \\
\hline 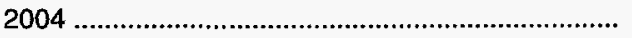 & 44,583 & 293,385 & 48,715 & 270,208 \\
\hline 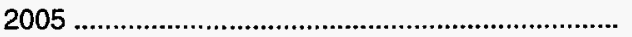 & NR & - & 43,759 & 313,967 \\
\hline
\end{tabular}

NR=Not Reported. --=Not applicable.

Source: Energy Information Administration: 1994-1995-Form ElA-858, "Uranium Industry Annual Survey" (1994-1995). 
Table 21. Anticipated Uranium Market Requirements of U.S. Utilities, 1996-2005, as of December 31, 1995

(Thousand Pounds $\mathrm{U}_{3} \mathrm{O}_{8}$ Equivalent)

\begin{tabular}{|c|c|c|c|c|}
\hline Year & $\begin{array}{l}\text { Quantity of Uranium Under } \\
\text { Purchase Contracts }\end{array}$ & Unfilled Requirements & $\begin{array}{l}\text { Anticipated Market } \\
\text { Requirements }\end{array}$ & Enrichment Feed Deliveries \\
\hline $1996 \ldots \ldots . . . . . . . .$. & 37,787 & 5,063 & 42,850 & 49,080 \\
\hline $1997 \ldots \ldots \ldots . . .$. & 33,286 & 8,285 & 41,571 & 42,182 \\
\hline $1998 \ldots \ldots \ldots \ldots$ & 31,071 & 15,709 & 46,780 & 52,936 \\
\hline 1999 & 18,989 & 23,200 & 42,189 & 37,733 \\
\hline $2000 \ldots \ldots \ldots . . .$. & 19,602 & 34,497 & 54,099 & 47,625 \\
\hline 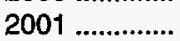 & 10,966 & 42,600 & 53,566 & 35,066 \\
\hline $2002 \ldots \ldots \ldots \ldots$ & 9,157 & 43,184 & 52,341 & 38,340 \\
\hline $2003 \ldots \ldots \ldots \ldots$ & 4,350 & 48,955 & 53,305 & 36,206 \\
\hline 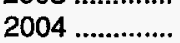 & 3,049 & 48,715 & 51,764 & 40,353 \\
\hline $2005 \ldots . . . . \ldots \ldots . . . . .$. & 2,468 & 43,759 & 46,227 & 30,373 \\
\hline Total ................ & 170,725 & 313,967 & 484,692 & 409,894 \\
\hline
\end{tabular}

Source: Energy Information Administration, Form EIA-858, "Uranium Industry Annual Survey" (1995).

Table 22. U.S. Utilities Deliveries of Uranium Feed by Enrichment Country and Delivery Year, 1994-1995

(Thousand Pounds $\mathrm{U}_{3} \mathrm{O}_{8}$ Equivalent)

\begin{tabular}{|c|c|c|c|c|c|c|}
\hline \multirow[b]{2}{*}{ Enrichment Plant Location } & \multicolumn{3}{|c|}{ Actual Deliveries in 1994} & \multicolumn{3}{|c|}{ Actual Deliveries in 1995} \\
\hline & U.S.-Origin & $\begin{array}{c}\text { Foreign- } \\
\text { Origin }\end{array}$ & Total & U.S.-Origin & $\begin{array}{c}\text { Foreign- } \\
\text { Origin }\end{array}$ & Tota \\
\hline China .................................................... & $w$ & W & W & 0 & 0 & 0 \\
\hline 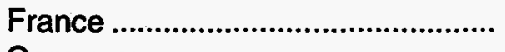 & W & W & 1,111 & $w$ & $w$ & 4,802 \\
\hline Germany & 0 & 0 & 0 & $w$ & W & 870 \\
\hline 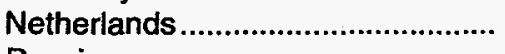 & 0 & 1,012 & 1,012 & W & W & 951 \\
\hline Russia & $W$ & W & 1,345 & 837 & 1,874 & 2,711 \\
\hline South Africa ........................................ & 0 & 0 & 0 & 0 & 0 & 0 \\
\hline 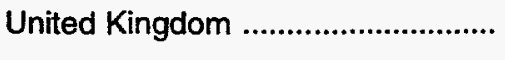 & 0 & $\mathbf{w}$ & W & 0 & 1,059 & 1,059 \\
\hline 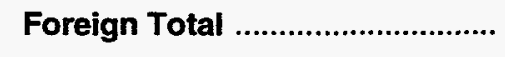 & $\mathbf{5 1}$ & 4,059 & 4,110 & 1,390 & 9,003 & 10,393 \\
\hline 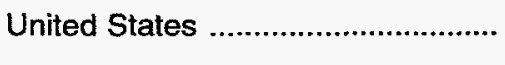 & 8,471 & 25,027 & 33,498 & 7,786 & 26,115 & 33,901 \\
\hline 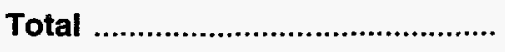 & 8,522 & 29,086 & 37,608 & 9,176 & 35,118 & 44,294 \\
\hline
\end{tabular}

$W=$ Data withheld to avoid disclosure.

Sources: Energy Information Administration: 1994-Uranium Industry Annual 1994 (July 1995); 1995-Form ElA-858, "Uranium Industry Annual Survey" (1995). 
Table 23. U.S. Utilities Deliveries of Uranium Feed for Enrichment by Origin Country and Delivery Year, 1994-1995

(Thousand Pounds $\mathrm{U}_{3} \mathrm{O}_{8}$ Equivalent)

\begin{tabular}{|c|c|c|}
\hline Actual Deliveries of Feed by Origin Country & 1994 & 1995 \\
\hline Australia & 2,880 & 3,300 \\
\hline Brazil & W & W \\
\hline Canada & 14,868 & 17,719 \\
\hline China & 1,429 & $\mathbf{W}$ \\
\hline France & W & W \\
\hline Gabon & W & 218 \\
\hline Germany & W & 365 \\
\hline Kazakhstan & 3,470 & 2,469 \\
\hline Kyrgyzstan & $W$ & W \\
\hline Mongolia & W & W \\
\hline Namibia & 804 & 738 \\
\hline Russia & 1,764 & 7,008 \\
\hline South Africa & 1,195 & 709 \\
\hline Spain & W & W \\
\hline Tajikistan & 0 & 805 \\
\hline Ukraine & $W$ & 401 \\
\hline United Kingdom & W & W \\
\hline Uzbekistan & 715 & 514 \\
\hline 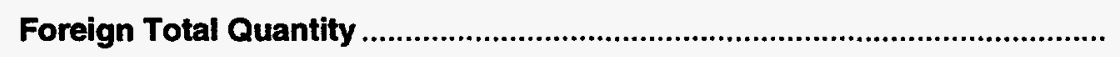 & 29,086 & 35,118 \\
\hline United States & 8,522 & 9,176 \\
\hline Total Quantity & 37,608 & 44,294 \\
\hline
\end{tabular}

$W=$ Data withheld to avoid disclosure.

Source: Energy Information Administration: 1994-1995-Form ElA-858, "Uranium Industry Annual Survey" (1994-1995).

Table 24. Shipments of Uranium by U.S. Utilities to Domestic and Foreign Enrichment Suppliers, 1996-2005

(Thousand Pounds $\mathrm{U}_{3} \mathrm{O}_{8}$ Equivalent)

\begin{tabular}{|c|c|c|c|c|}
\hline \multirow[b]{2}{*}{ Year of Shipment } & \multicolumn{2}{|c|}{ Amount to be Shipped } & \multicolumn{2}{|c|}{ Change from 1994 to 1995} \\
\hline & $\begin{array}{c}\text { As of } \\
\text { December 31, 1994 }\end{array}$ & $\begin{array}{c}\text { As of } \\
\text { December 31, } 1995\end{array}$ & Annual & Cumulative \\
\hline 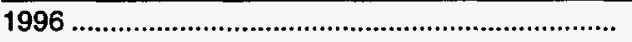 & 47,401 & 49,080 & 1,679 & 1,679 \\
\hline 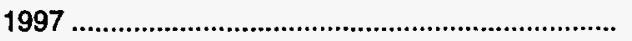 & 42,169 & 42,182 & 13 & 1,692 \\
\hline 1998 & 43,487 & 52,936 & 9,449 & 11,141 \\
\hline 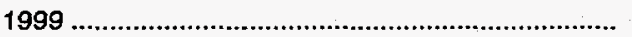 & 43,202 & 37,733 & $-5 ; 469$ & 5,672 \\
\hline 2000 & 40,917 & 47,625 & 6,708 & 12,380 \\
\hline 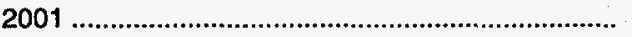 & 38,002 & 35,066 & $-2,936$ & 9,444 \\
\hline 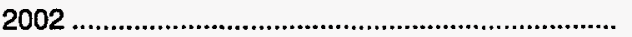 & 40,330 & 38,340 & $-1,990$ & 7,454 \\
\hline 2003 & 35,536 & 36,206 & 670 & 8,124 \\
\hline 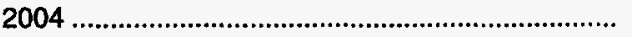 & 36,046 & 40,353 & 4,307 & 12,431 \\
\hline 2005 & NR & 30,373 & -- & -. \\
\hline
\end{tabular}

NR=Not reported. --Not applicable.

Source: Energy Information Administration: 1994-1995-Form ElA-858, "Uranium Industry Annual Survey" (1994-1995). 
Table 25. U.S. Utilities Purchases of Enrichment Services by Country and Delivery Year, 1994-1995

(Thousand Separative Work Units (SWU))

\begin{tabular}{|c|c|c|}
\hline Actual Deliveries & 1994 & 1995 \\
\hline \multicolumn{3}{|l|}{ Country where Enrichment Service was performed: } \\
\hline $\begin{array}{l}\text { China } \\
\text { France } \\
\text { Germany } \\
\text { Russia } \\
\text { South Africa } \\
\text { United Kingdom }\end{array}$ & $\begin{array}{r}237 \\
549 \\
W \\
W \\
421 \\
0 \\
W\end{array}$ & $\begin{array}{r}0 \\
867 \\
W \\
W \\
1,108 \\
0 \\
460\end{array}$ \\
\hline Foreign Total & 1,676 & 2,800 \\
\hline 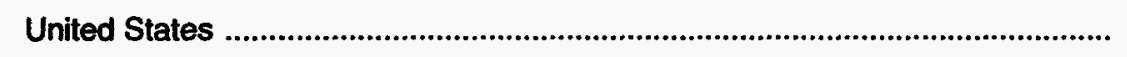 & 7,521 & 6,741 \\
\hline Total & 9,197 & 9,540 \\
\hline
\end{tabular}

W=Data withheld to avoid disclosure.

Note: Totals may not equal sum of components because of independent rounding.

Source: Energy Information Administration: 1994-1995-Form ElA-858, "Uranium Industry Annual Survey" (1994-1995).

Table 26. U.S. Utilities Purchases of Enrichment Services by Contract Type in Delivery Year 1995 (Thousand Separative Work Units (SWU))

\begin{tabular}{|c|c|c|c|}
\hline Enrichment Service Contract Type & U.S. Enrichment & Foreign Enrichment & Total \\
\hline Spot & 0 & 365 & 365 \\
\hline Short-term & 0 & 0 & 0 \\
\hline 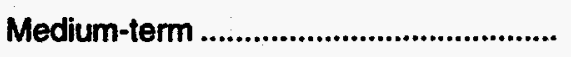 & 386 & 819 & 1,205 \\
\hline Long-term & 6,355 & 1,615 & 7,970 \\
\hline Total & 6,741 & 2,800 & 9,540 \\
\hline
\end{tabular}

Note: Totals may not equal sum of components because of independent rounding.

Source: Energy Information Administration, Form EIA-858, "Uranium Industry Annual Survey" (1995).

Table 27. Uranium Loaded into Fuel Assemblies for Commercial Nuclear Reactors by Year, 1994-1995

(Thousand Pounds $\mathrm{U}_{3} \mathrm{O}_{8}$ Equivalent)

\begin{tabular}{|c|c|c|}
\hline Origin of Uranium & 1994 & $1995^{p}$ \\
\hline $\begin{array}{l}\text { Domestic-Origin Uranium } \\
\text { Foreign-Orign Uranium }\end{array}$ & $\begin{array}{r}R 9,302 \\
R 31,098\end{array}$ & $\begin{array}{l}11,146 \\
39,972\end{array}$ \\
\hline Total & $R 40,400$ & 51,118 \\
\hline
\end{tabular}

P = Preliminary data. $\mathbf{R}=$ Revised data. Final 1994 fuel assembly data reported in the 1995 survey.

Notes: Includes only unirradiated uranium in new fuel assemblies loaded into reactors during the year. Does not include uranium removed from reactors that subsequently will be reloaded. Totals may not equal sum of components because of independent rounding.

Source: Energy Information Administration, Form ElA-858, "Uranium Industry Annual Survey" (1995). 
Table 28. Imports of Uranium by U.S. Suppliers, U.S. Utilities and Delivery Year, 1994-1995 (Thousand Pounds $\mathrm{U}_{3} \mathrm{O}_{8}$ Equivalent; Dollars per Pound $\mathrm{U}_{3} \mathrm{O}_{8}$ Equivalent)

\begin{tabular}{|c|c|c|}
\hline Actual Deliveries & 1994 & 1995 \\
\hline 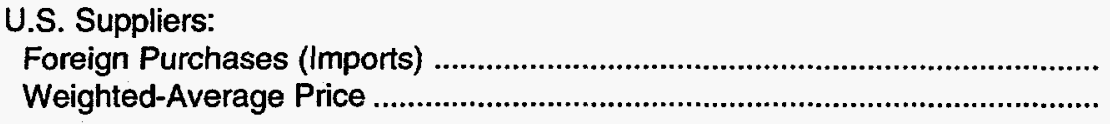 & $\begin{array}{r}21,082 \\
7.78\end{array}$ & $\begin{array}{r}20,162 \\
8.96\end{array}$ \\
\hline $\begin{array}{l}\text { U.S. Utilities: } \\
\text { Foreign Purchases (Imports) } \\
\text { Weighted-Average Price }\end{array}$ & $\begin{array}{r}15,536 \\
10.53\end{array}$ & $\begin{array}{r}21,139 \\
11.39\end{array}$ \\
\hline $\begin{array}{l}\text { U.S. Suppliers and U.S. Utilities: } \\
\text { Foreign Purchases (Imports) } \\
\text { Weighted-Average Price }\end{array}$ & $\begin{array}{r}36,618 \\
8.95\end{array}$ & $\begin{array}{r}41,301 \\
10.20\end{array}$ \\
\hline
\end{tabular}

Source: Energy Information Administration, Form EIA-858, "Uranium Industry Annual Survey" (1994-1995).

Table 29. U.S. Brokers and Traders Purchases of Uranium by Material Origin, Supplier, and Delivery Year, 1994-1995

(Thousand Pounds $\mathrm{U}_{3} \mathrm{O}_{8}$ Equivalent; Dollars per Pound $\mathrm{U}_{3} \mathrm{O}_{8}$ Equivalent)

\begin{tabular}{|c|c|c|}
\hline Actual Deliveries & 1994 & 1995 \\
\hline \multicolumn{3}{|l|}{ Received by U.S. Brokers and Traders of U.S.-Origin Uranium: } \\
\hline Purchases & 4,792 & 3,356 \\
\hline Weighted-Average Price & 9.75 & 11.51 \\
\hline \multicolumn{3}{|l|}{ Received by U.S. Brokers and Traders of Foreign-Origin Uranium: } \\
\hline 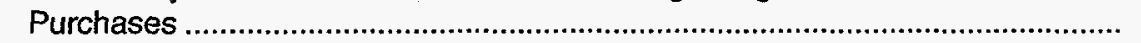 & 26,011 & 19,593 \\
\hline 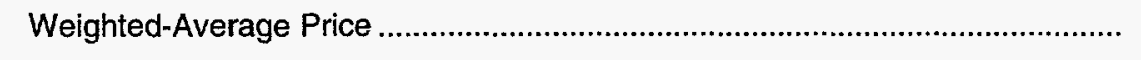 & 8.02 & 9.20 \\
\hline \multicolumn{3}{|l|}{ Total Received by U.S. Brokers and Traders: } \\
\hline Purchases & 30,803 & 22,949 \\
\hline 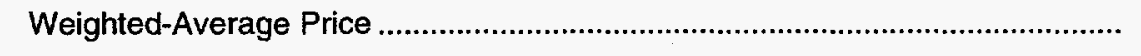 & 8.29 & 9.53 \\
\hline \multicolumn{3}{|l|}{ Received by U.S. Brokers and Traders from Foreign Suppliers: } \\
\hline Purchases & 22,328 & 18,311 \\
\hline 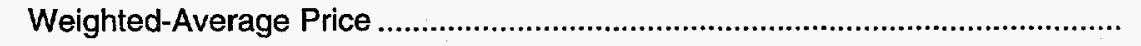 & 7.87 & 9.02 \\
\hline
\end{tabular}

Source: Energy Information Administration, Form ElA-858, "Uranium Industry Annual Sunvey" (1994-1995). 
Table 30. Uranium Exports to Foreign Suppliers and Utilities by Origin andDelivery Year, 1994-1995

(Thousand Pounds $\mathrm{U}_{3} \mathrm{O}_{8}$ Equivalent; Dollars per Pound $\mathrm{U}_{3} \mathrm{O}_{8}$ Equivalent)

\begin{tabular}{|c|c|c|}
\hline Actual Deliveries to Foreign Suppliers and Utilities & 1994 & 1995 \\
\hline \multicolumn{3}{|l|}{ U.S.-Origin Uranium: } \\
\hline 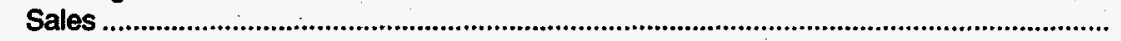 & 5,941 & 4,713 \\
\hline 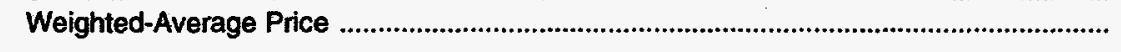 & 18.41 & 17.34 \\
\hline \multicolumn{3}{|l|}{ Foreign-Origin Uranium: } \\
\hline 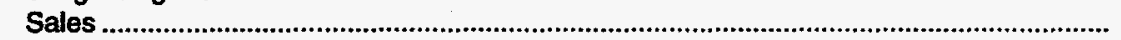 & 11,799 & 5,123 \\
\hline Weighted-Average Price & 7.78 & 9.94 \\
\hline \multicolumn{3}{|l|}{ Total Exports: } \\
\hline Sales & 17,740 & 9,836 \\
\hline Weighted-Average Price & 11.34 & 13.48 \\
\hline \multicolumn{3}{|l|}{ Exports by U.S. Producers, U.S. Utilities, and Other Suppliers: } \\
\hline Sales & 4,930 & 4,342 \\
\hline Weighted-Average Price & 20.09 & 18.11 \\
\hline \multicolumn{3}{|l|}{ Exports by U.S. Brokers and Traders: } \\
\hline Sales & 12,810 & 5,494 \\
\hline Weighted-Average Price & 7.98 & 9.83 \\
\hline
\end{tabular}

Note: "Other U.S. Stppliers" are U.S. converters, enrichers, and fabricators.

Source: Energy Information Administration, Form EIA-858, "Uranium Industry Annual Survey" (1994-1995).

Table 31. Inventories of Natural and Enriched Uranium as of End of Year, 1994-1995 (Thousand Pounds $\mathrm{U}_{3} \mathrm{O}_{8}$ Equivalent)

\begin{tabular}{|c|c|c|}
\hline \multirow[b]{2}{*}{ Type of Uranium Inventory } & \multicolumn{2}{|c|}{ Inventories at the End of the Year } \\
\hline & 1994 & $1995^{P}$ \\
\hline $\begin{array}{l}\text { U.S. Utility Inventories } \\
\text { Natural Uranium } \\
\text { Enriched Uranium }\end{array}$ & $\begin{array}{l}R 65,410 \\
R 42,417 \\
R 22,993\end{array}$ & $\begin{array}{l}56,214 \\
40,458 \\
15,756\end{array}$ \\
\hline $\begin{array}{l}\text { U.S. Supplier Inventories } \\
\text { Natural Uranium } \\
\text { Enriched Uranium }\end{array}$ & $\begin{array}{r}R 21,469 \\
R 17,413 \\
R 4,056\end{array}$ & $\begin{array}{r}13,916 \\
13,505 \\
411\end{array}$ \\
\hline Total Commercial Inventories... & R86,879 & 70,129 \\
\hline $\begin{array}{l}\text { DOE-Owned and USEC-Held Inventories } \\
\text { Natural Uranium } \\
\text { Enriched Uranium }\end{array}$ & $\begin{array}{l}\text { R85,210 } \\
\text { R57,176 } \\
\text { R28,034 }\end{array}$ & $\begin{array}{r}110,792 \\
81,982 \\
28,810\end{array}$ \\
\hline
\end{tabular}

ancludes amounts reported as inventories of UF ${ }_{6}$ at Enrichment Suppliers.

-Includes amounts reported as inventories by U.S. Department of Energy (DOE) and the United States Enrichment Corporation (USEC).

$P=$ Preliminary data. $R=$ Revised data. Final 1994 inventory data reported in the 1995 survey.

Note: Totals may not equal sum of components because of independent rounding.

Source: Energy Information Administration, Form ElA-858, "Uranium Industry Annual Sunvey" (1995). 
Table 32. Commercial Uranium Inventories by Type and Location at End of Year, 1994-1995 (Thousand Pounds $\mathrm{U}_{3} \mathrm{O}_{8}$ Equivalent)

\begin{tabular}{|c|c|c|c|c|c|c|}
\hline \multirow[b]{2}{*}{ Material Type and Location } & \multicolumn{2}{|c|}{ U.S. Utilities } & \multicolumn{2}{|c|}{ U.S. Suppliers } & \multicolumn{2}{|c|}{$\begin{array}{l}\text { U.S. Utilities and } \\
\text { Suppliers }\end{array}$} \\
\hline & 1994 & $1995^{P}$ & 1994 & $1995^{P}$ & 1994 & $1995^{P}$ \\
\hline $\mathrm{U}_{3} \mathrm{O}_{8}$ on hand, in off-site storage, or at conversion plants & $\mathbf{R 2 1 , 2 9 6}$ & 22,693 & $\mathbf{R 1 3 , 0 8 4}$ & 11,593 & $\mathbf{R 3 4 , 3 8 0}$ & 34,287 \\
\hline $\begin{array}{l}\text { Natural } \text { UF }_{6} \\
\text { on hand, in private off-site storage, or at conversion }\end{array}$ & $\mathbf{R 2 1 , 1 2 1}$ & 17,764 & $\mathbf{R 4 , 3 2 9}$ & 1,911 & $\mathbf{R 2 5 , 4 5 0}$ & 19,676 \\
\hline plants & $\mathbf{w}$ & W & $\mathbf{w}$ & $\mathbf{w}$ & R5,085 & 5,579 \\
\hline delivered to enrichment plants under usage agreements .... & W & W & W & W & $\mathbf{R} 11,398$ & 6,102 \\
\hline 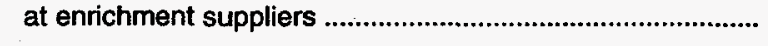 & R6,989 & 6,975 & $\mathbf{R} 1,978$ & 1,020 & R8,967 & 7,995 \\
\hline Enriched UF ${ }_{6}$ & $\mathbf{R 2 2 , 9 9 3}$ & 15,756 & $\mathbf{R 4 , 0 5 6}$ & 411 & $\mathbf{R} 27,049$ & 16,167 \\
\hline 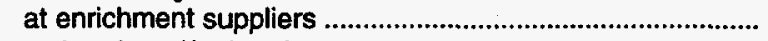 & W & W & w & 113 & R3,945 & 1,606 \\
\hline $\begin{array}{l}\text { on hand, and/or in private storage } \\
\text { as fabricated fuel not inserted into a reactor, on hand, }\end{array}$ & W & W & $\mathbf{w}$ & 298 & $\mathrm{R} 8,874$ & 6,828 \\
\hline and/or in private storage & $\mathrm{R} 14,231$ & 7,733 & 0 & 0 & $\mathrm{R} 14,231$ & 7,733 \\
\hline 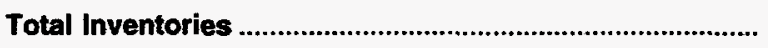 & $\mathbf{R} 65,410$ & 56,214 & $\mathbf{R 2 1 , 4 6 9}$ & 13,916 & $\mathbf{R 8 6 , 8 7 9}$ & 70,129 \\
\hline
\end{tabular}

$P=$ Preliminary data. $R=$ Revised data. Final 1994 inventory data reported in the 1995 survey. $W=$ Data withneld to avoid disclosure. Note: Totals may not equal sum of components because of independent rounding.

Source: Energy Information Administration, Form EIA-858, "Uraniurn Industry Annual Survey (1995).

Table 33. Commercial Uranium Inventories by Type and Owner at End of Year, 1994-1995 (Thousand Pounds $\mathrm{U}_{3} \mathrm{O}_{8}$ Equivalent)

\begin{tabular}{|c|c|c|c|c|c|c|}
\hline \multirow[b]{2}{*}{ U.S. Firms } & \multicolumn{2}{|c|}{$\mathrm{U}_{3} \mathrm{O}_{8}$} & \multicolumn{2}{|c|}{ Natural and Enriched UF } & \multicolumn{2}{|c|}{ Total } \\
\hline & 1994 & $1995^{P}$ & 1994 & $1995^{P}$ & 1994 & $1995^{P}$ \\
\hline 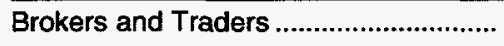 & $\mathrm{R} 7,480$ & 5,404 & $R 4,250$ & 1,295 & $R 11,729$ & 6,698 \\
\hline Converter and Fabricators ......................... & 0 & 0 & R4,136 & 1,027 & $R 4,136$ & 1,027 \\
\hline Producers & $\mathrm{R} 5,604$ & 6,190 & 0 & 0 & $\mathrm{R} 5,604$ & 6,190 \\
\hline 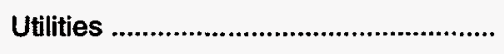 & R21,296 & 22,693 & $\mathrm{R} 44,114$ & 33,520 & $\mathrm{R} 65,410$ & 56,214 \\
\hline Total Commercial Inventories ............ & $\mathbf{R 3 4 , 3 8 0}$ & 34,287 & R52,499 & 35,843 & $\mathbf{R} 86,879$ & 70,129 \\
\hline
\end{tabular}

$P=$ Preliminary data. $R=$ Revised data. Final 1994 inventory data reported in the 1995 survey.

Note: Totals may not equal sum of components because of independent rounding.

Source: Energy Information Administration, Form EIA-858, "Uranium Industry Annual Survey" (1995). 

Appendix A

Survey

Methodology 



\section{Appendix A}

\section{Survey Methodology}

\section{Survey Design}

The 12th comprehensive survey of the U.S. uranium industry was conducted in 1996 by the Energy Information Administration (EIA) using the "Uranium Industry Annual Survey," Form EIA-858. EIA collected data from all companies involved in the U.S. uranium industry, mailing the survey form to these firms in December 1995. The data reported in this publication were developed from the 1995 survey and predecessor databases.

EIA asked respondents to the "Uranium Industry Annual Survey" to provide data current to the end of 1995 about the following:

Uranium raw materials activities, including: land holdings, exploration and development activities, uranium-bearing properties and reserves, uranium mines, uranium processing facilities, and uranium industry employment in the raw materials sector

Uranium marketing activities, including contracts, contract prices and delivery schedules, uranium inventories, enrichment feed deliveries, unfilled market requirements, uranium used in fuel assemblies, and purchases of entichment services.

The data collected on Form EIA-858 are subject to various sources of error. These sources are: (1) coverage (the list of respondents might not be complete or, on the other hand, there might be double counting); (2) non-response (all units that are surveyed might not respond or not provide all the information requested); (3) respondents (respondents might commit errors in reporting the data); (4) processing (the data collection agency might omit or incorrectly transcribe a submission); (5) concept (the data collection elements might not measure the items they were intended to measure); and (6) adjustments (errors might be made in estimating values for missing data). Because the "Uranium Industry Annual Survey" is not a sample survey, the estimates shown in this report are not subject to sampling error. ${ }^{1}$ Although it is not possible to present estimates of nonsampling error, precautionary steps were taken at each stage of the survey design to minimize the possible occurrence of these errors. The steps are described below, with the error they were designed to minimize shown in parenthesis.

\section{Survey Universe and Frame (Coverage Errors)}

The survey universe includes all companies involved in the U.S. uranium industry. The universe includes all firms meeting one or more of the following criteria: (1) are controllers or were controllers during any portion of 1995, or are identified in EIA records as the most recent controllers of uranium properties, mines, mills, or plant; (2) involved as controllers of uranium exploration and development ventures in the United States; (3) incurred uranium exploration expenditures in 1995 or plan such expenditures in 1996; (4) hold uranium reserves; (5) control uranium mining properties; (6) control commercial uranium extraction operations; and (7) purchase, sell, held, or own domestic- or foreign-origin uranium; offered uranium enrichment services; imported or exported uranium; and (utilities only) purchased uranium enrichment services from an enrichment supplier.

The respondent list used for the Form EIA-858 survey was developed from a frame of all establishments known to meet the selection criteria. The frame of potential respondents was compiled from previous surveys and from information in the public domain. The frame was intended to cover the following: all utilities owning nuclearfueled generating stations; uranium converters, enrichers, and fuel fabricators; uranium traders and brokers; large and small companies actively engaged in exploration, development, or extraction in the U.S. uranium industry; and companies holding all large properties with uranium reserves. Companies meeting these criteria include: those involved in exploration, development, mining, milling, and trading of uranium; landowners; uranium converters, enrichers, and fabricators; and utilities with whole or partial ownership in operating or planned nuclear electric power plants.

\section{Survey Procedures (Nonresponse)}

The survey forms were sent via first class mail to ensure their receipt only by the proper respondent organization. If the U.S. Postal Service was unable to deliver the survey form, the corrected address was obtained where possible. In a few instances, businesses that had reported in

'Sampling error is a measure of the variation that occurs by chance because a sample rather than a complete enumeration of units is surveyed. 
earlier surveys were no longer operating. All known companies currently conducting business in the U.S. uranium industry were contacted during this survey.

Form EIA-858, "Uranium Industry Annual Survey," requests data about many areas of company operations. The scope of the questions is necessarily broad, and selfreporting of company-specific data isrequired.

Cooperation from industry on the 1995 survey was good. About 55 percent of respondents replied to the form within the specified deadline. Those that had not responded by the due date (March 1st for Schedules A and B) were telephoned to encourage submission of the forms, and those calls resulted in the submission of most of the remaining forms. Subsequently, telephone calls were made to obtain forms not yet submitted. In a few instances, company data were collected through telephone conversations.

\section{Data Editing, Analysis, and Processing (Respondent and Processing Errors)}

The survey forms are logged in and reviewed by agency personnel prior to data entry into the Uranium Industry Annual System, an automated database containing all current and historical data from each company's submissions. The database is maintained on the EIA computer facility in Washington, DC. After entry into the database, a copy of each part of the Form EIA-858 was distributed to the Analysis and Systems Division analyst responsible for that part. The submissions were checked for internal consistency, and the reported data were compared with previous collections of similar data. After reviewing these submissions, the analyst consulted with the reporting company, as needed, to resolve data problems and to confirm any corrections of the data.

Data areas that were reviewed and the corrections that were made differed from company to company. Most represented different interpretations of the data item definitions. No data in the database were changed without first consulting with the reporting company. Computer edits were also used to identify keypunch errors, out-ofrange values, and unlikely data combinations. These also were either corrected to represent the data reported on the submissions or were changed only after confirming the corrected values by telephone conversations with company representatives. Data coding and entry errors were eliminated by proofing data after entry. All changes to reported data are documented.

\section{Response Rates}

For the 1995 Form EIA-858 survey, Schedule A, "Uranium Raw Materials Activities," was mailed to 48 firms and Schedule B, "Uranium Marketing Activities," was mailed to 87 firms. Response statistics are shown in Table A1. Overall, 100 percent of the firms responded to EIA with the data as requested for the survey sections as applicable to individual firms.

Table A1. Response Statistics for the 1995 Uranium Industry Annual Survey

\begin{tabular}{|c|c|c|}
\hline \multirow[b]{2}{*}{ Response Status } & \multicolumn{2}{|c|}{ Schedule } \\
\hline & A & B \\
\hline 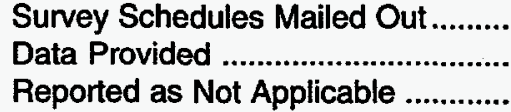 & $\begin{array}{c}48 \\
45 \\
3\end{array}$ & $\begin{array}{c}87 \\
84 \\
3\end{array}$ \\
\hline
\end{tabular}

Source: Energy Information Administration, Form ElA-858, "Uranium Industry Annual Sunvey" (1995).

\section{Missing Data}

Some omissions of data were identified during the prescreening and editing of the data. Most omitted data elements fell into two categories: particular data were unknown or inadvertent omissions. ELA contacted respondents to obtain omitted data or to verify that they could not be reported. Only confirmed company-reported data are contained in the database and included in this report.

\section{Data Revisions}

The Office of Coal, Nuclear, Electric and Alternate Fuels, Energy Information Administration, has adopted the following policy for review and correction (revision) of data it collects and publishes. The policy covers revisions to prior published data. This new policy was initially implemented with the publication of the Uranium Industry Annual 1992.

1. Annual survey data are published either as preliminary or final when they first appear in a data report. Data released as preliminary will be identified as such. When necessary, preliminary data will be revised and declared to be final at the next publication of that data. 
2. Monthly and quarterly survey data are published initially as preliminary data. They will be revised only after the completion of the data collection cycle for the full 12-month survey period. Revisions will not be made to monthly or quarterly data prior to this time.

3. The magnitude of historical data revisions experienced will be included in each data report to inform the reader about the accuracy of the data presented.

4. Revisions to data published as final will be made only in the event that newly available information would result in a change to published data of more than than 1 percent at the national level. Revisions for changes of lesser magnitudes will be made at the discretion of the Office Director.

All data, except for uranium inventory data and uranium fuel assembly data, are published as final. Data on uranium inventories and fuel assemblies for the survey year are published as preliminary because survey respondents are requested to make changes to their prior year data, if necessary, when reporting data for the current survey year. These revised data are indicated by an " $R$ " in front of the revised table cell.

Changes to the prior year's total uranium inventory figures based on revisions reported on Form ELA-858 was for 1994, 0.6 million pounds $\mathrm{U}_{3} \mathrm{O}_{8} \mathrm{e}$ (0.1 percent). For uranium fuel assemblies, changes for 1994 was 1.4 million pounds $\mathrm{U}_{3} \mathrm{O}_{8}$ e ( 3.5 percent).

\section{Nondisclosure of Data}

To protect the confidentiality of individual respondents' data, a policy was implemented to ensure that the reporting of survey data in this publication would not associate those data with a particular company. This is in compliance with EIA Standard No. 88-05-06, "Nondisclosure of Company Identifiable Data in Aggregate Cells." In tables where the nonzero value of a cell is composed of data from fewer than three companies or if a single company dominates a table-cell value so that the publication of the value would lead to identification of a company's data, then the EIA classifies the cell value as "sensitive," and the cell value is withheld ("W") from publication. Within a table with a sensitive cell value, selected values in other cells of the table are also withheld, as necessary, so that the sensitive cell valuecannot be computed using the values in published cells. A sensitive table-cell value can be reported, if each company whose data contribute to the sensitivity, gives permission to publish the value and if the company believes that publishing it would not harm the company's competitive position. This is the only exception to the application of EIA Standard No. 88-05-06 in this report. 

Appendix B

Resources and Reserves 



\section{Appendix B}

\section{Resources and Reserves}

This section discusses the methodologies used to estimate the U.S. uranium resources. Three classes of resources are estimated: Reserves, Estimated Additional Resources (EAR), and Speculative Resources (SR). EAR and SR categories are undiscovered potential.

A diagram showing a comparison of nomenclatural schemes used by the EIA and DOE's predecessor agencies for reporting estimates of U.S. uranium resources since 1974 is provided in Figure B1.

\section{Appraisal of Potential Resources}

The appraisal of the National potential resources of uranium, which comprise the Estimated Additional Resources (EAR) and Speculative Resources (SR) categories, is based on extensive data collected under the uranium resource appraisal program of DOE and its predecessor agencies. These data include: chemical assays of core samples; data from geochemical surveys of groundwater, stream water and sediment; aerial radiometric surveys; limited selective drilling to fill voids in subsurface information; and geological studies of field areas throughout the United States.

Estimates of potential resources are based on data developed under the DOE National Uranium Resource Evaluation (NURE) program and under a Memorandum of Understanding signed in 1984 between EIA and the U.S. Geological Survey of the Department of Interior. Annual updating of the estimates by EIA was discontinued after 1994. Therefore, 1995 potential resources are the same as those reported for the previous year. Estimates of uranium resources in the EAR and SR classes for 1986 through 1995 are shown in Table B1. Resource quantities of EAR and SR are summarized for principal resource regions and forward-cost categories in Table B2.

\section{Estimation of Reserves}

Uranium reserves are the estimated quantities of uranium that occur in known deposits of such grade, quantity, configuration, and depth that they can be recovered under current regulations at or below a specified cost with state-of-the-art mining and processing technology. Estimated reserves are based on direct radiometric and chemical measurements in drill hole samples. Ore grades and thickness, spacial relationships, depths, mining and reclamation methods, haulage distance, and amenability of ore within specific forward-cost levels are considered in the evaluation. Uranium reserves estimated by the DOE have been adjusted for appropriate mining dilution and mill recovery.

The costs used to categorize uranium reserves are forward costs (see Glossary) in current (year of estimate) dollars that would be incurred in producing the uranium. The costs include power and fuel, labor, materials, royalties, severance and ad valorem taxes, insurance, and applicable administrative costs. Previous expenditures (sunk costs) for such item as exploration and land acquisition are excluded. Also excluded are income taxes, profit, and the cost of money. The forward-cost categories are independent of the market price at which the uranium might be sold.

The current uranium reserve estimates are based on a combination of EIA-held historical property data, company-reported data, and independent reserve estimates. The estimates of national uranium reserves also are based on current knowledge about domestic deposits and on adjustments for depletion and erosion of specific cost category reserves due to production of ore from individual property. Current and historical estimates of reserves since 1986 are shown in Table B3. Reserve estimates of each forward-cost category are summarized for major States in Table B4. 
Figure B1. Comparison of Historical and Current U.S. and NEAIAEA Classification Nomenclatures for Uranium Resources
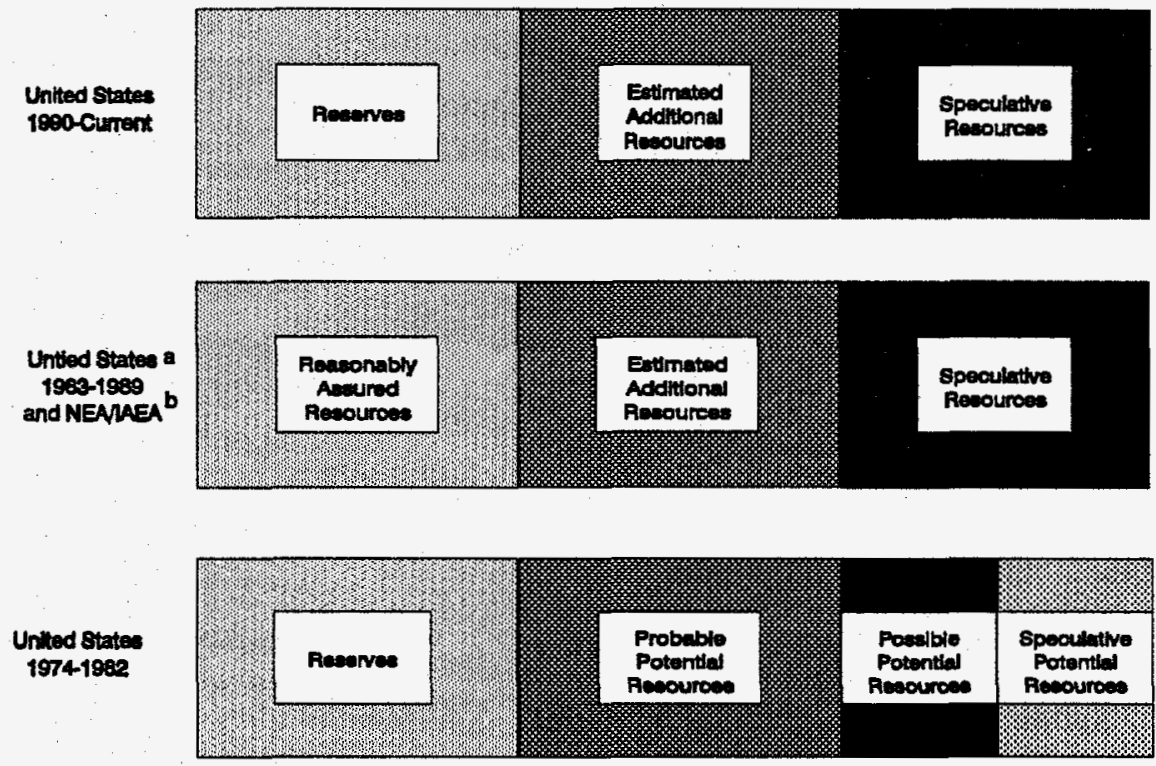

This nomenclature was adopled in 1983 by the U.S. Department of Energy and was patterned after the Nuclear Energy Agency/International Atomic Energy Agency Standard.

The classifications shown for the United States prior to and after 1983 and the NEAIAEA are not strictly comparable, because the criteria used in the individual systems are not identical. Precise correlations are not possible, particularly for the less assured resources. Nonetheless, based on the principal criterion of geological assurance of existence, this figure presents a reasonable approximation of uranium resources classification comparability.

'NEAIAEA: Nuclear Energy Agency/lnternational Alomic Energy Agency.

Note: The NEAMAEA separates the Estimaled Additional Resources (EAR) into Categories I and II based primarily on geological inference. Categories I and II of EAR are not utilized for estimates of resources in the United States.

Source: Prepared by the Energy Information Administration, Office of Coal, Nuclear, Electric and Alternate Fuels.

Figure B2. Uranium Resource Regions of the United States

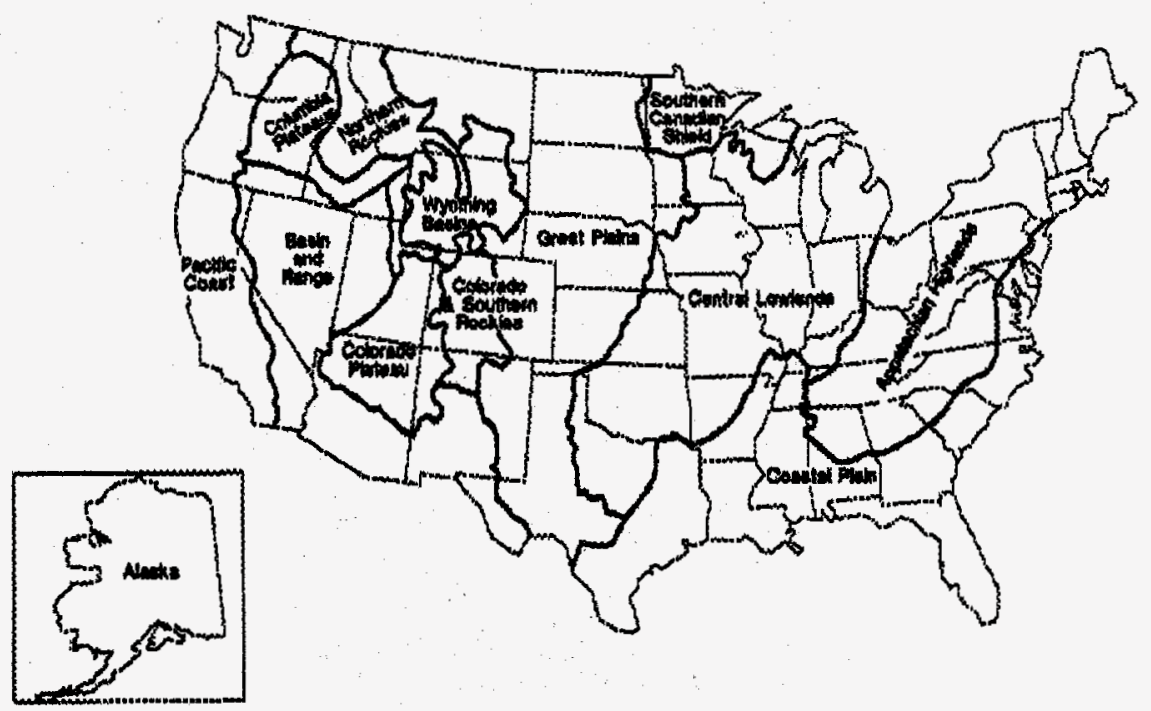

Source: U.S. Department of Energy, An Assessment Report on Uranlum in the United States of America, OJO-111(80) (Grand Junetion, Colorado, Ootober 1880). 
Table B1. U.S. Potential Uranium Resources by Forward-Cost Catagory and Resource Class, 1986-1995

(Million Pounds $\mathrm{U}_{3} \mathrm{O}_{8}$ )

\begin{tabular}{|c|c|c|c|c|c|c|}
\hline \multirow[b]{3}{*}{ Year } & \multicolumn{6}{|c|}{ Fonward-Cost Category } \\
\hline & \multicolumn{2}{|c|}{$\$ 30$ per pound } & \multicolumn{2}{|c|}{$\$ 50$ per pound } & \multicolumn{2}{|c|}{$\$ 100$ per pound } \\
\hline & EAR $^{a}$ & $\mathrm{SR}^{\circ}$ & EAR $^{*}$ & $\mathrm{SR}^{\mathrm{b}}$ & EAR $^{a}$ & $\mathrm{SR}^{\mathrm{b}}$ \\
\hline 1986 & 1,300 & 1,000 & 2,400 & 1,900 & 3,800 & 3,200 \\
\hline $1987 \ldots \ldots \ldots$ & 1,300 & 1,000 & 2,300 & 2,000 & 3,700 & 3,200 \\
\hline $1988 \ldots \ldots \ldots$ & 1,300 & 1,000 & 2,300 & 2,000 & 3,800 & 3,200 \\
\hline 1989 & 2,300 & 1,400 & 3,400 & 2,300 & 5,000 & 3,500 \\
\hline 1990 & 2,200 & 1,300 & 3,400 & 2,200 & 4,900 & 3,500 \\
\hline 1991 & 2,200 & 1,400 & 3,400 & 2,300 & 4,900 & 3,600 \\
\hline 1992 & 2,200 & 1,300 & 3,400 & 2,300 & 4,900 & 3,500 \\
\hline 1993 & 2,200 & 1,330 & 3,340 & 2,250 & 4,880 & 3,510 \\
\hline 1994 & 2,180 & 1,310 & 3,310 & 2,230 & 4,850 & 3,480 \\
\hline 1995 & 2,180 & 1,310 & 3,310 & 2,230 & 4,850 & 3,480 \\
\hline
\end{tabular}

aEAR = Estimated Additional Resources.

'SR = Speculative Resources.

Notes: Values shown are the mean values for the distribution of estimates for each forward-cost category: 1986-1992- rounded to the nearest 100 million pounds $\mathrm{U}_{3} \mathrm{O}_{8} ; 1993-1995$ - rounded to the nearest 10 million pounds $\mathrm{U}_{3} \mathrm{O}_{\mathrm{g}}$. Estimates of uranium that could be recovered as a byproduct of other commodities are not included. Resource values in forward-cost categories are cumulative: that is, the quantity at each level of fonward cost includes all resources at the lower cost in that category.

Sources: 1986-1988-Estimates based on uranium resources data developed under the EOE National Uranium Resource Evaluation (NURE) program, 1974-1983, using methodology described in An Assessment Report on Uranium in the United States of America (October 1980) in U.S. Department of Energy, Uranium Industry Seminar (October 1980); and under U. S. Geological Survey (USGS) Uranium Resource Assessment Project. 1989-1995Estimates based on urnaium resources data develpoed under the NURE program and USGS Uranium Resource Assessment Project using methodology described in Uranium Resource Assessment by the Geological Survey: Methodology and Plan to Update the National Resource Base, U.S. Geological Survey Circular 994 (1987). Estimates are updated annually by ElA using revised economic index values which reflect changes in the U.S. economy.

Table B2. U.S. Potential Uranium Resources by Forward-Cost Category and Resource Region, 1995

(Million Pounds $\mathrm{U}_{3} \mathrm{O}_{8}$ )

\begin{tabular}{|c|c|c|c|c|c|c|}
\hline \multirow[b]{3}{*}{ Resource Region } & \multicolumn{6}{|c|}{ Forward-Cost Category } \\
\hline & \multicolumn{2}{|c|}{$\$ 30$ per pound } & \multicolumn{2}{|c|}{$\$ 50$ per pound } & \multicolumn{2}{|c|}{$\$ 100$ per pound } \\
\hline & $\mathrm{EAR}^{\mathrm{a}}$ & $S^{b}$ & EAR $^{\mathbf{a}}$ & $S R^{b}$ & EAR $^{a}$ & $\mathrm{SR}^{\mathrm{b}}$ \\
\hline 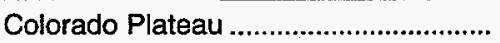 & 1,330 & 480 & 1,900 & 770 & 2,540 & 1,210 \\
\hline 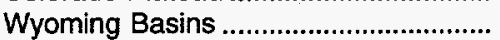 & 160 & 80 & 340 & 160 & 660 & 250 \\
\hline 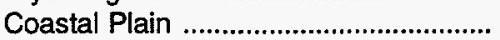 & 370 & 130 & 490 & 180 & 600 & 230 \\
\hline 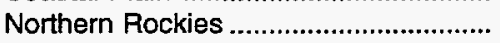 & 30 & 110 & 60 & 200 & 170 & 300 \\
\hline Colorado and Southern Rockies ........... & 140 & 90 & 180 & 140 & 220 & 190 \\
\hline 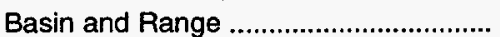 & 50 & 90 & 160 & 170 & 390 & 320 \\
\hline Other Regions ${ }^{c}$ & 110 & 330 & 180 & 610 & 270 & 990 \\
\hline Total & 2,180 & 1,310 & 3,310 & 2,230 & 4,850 & 3,480 \\
\hline
\end{tabular}

aEAR = Estimated Additional Resources.

bSR = Speculative Resources.

Includes Appalachian Highlands, Great Plains, Pacific Coast and Sierra Nevada, Central Lowlands, and Columbia Plateau regions and Alaska.

Notes: Values shown are the mean values for the distribution of estimates for each forward-cost category, rounded to the nearest 10 million pounds $\mathrm{U}_{3} \mathrm{O}_{8}$.

Estimates of uranium that could be recovered as a byproduct of other commodities are not included. Resource values in forward-cost categories are cumulative: that is, the quantity at each level of forward cost includes all resources at the lower cost in that category.

Sources: Prepared by the Energy Information Administration, Office of Coal, Nuclear, Electric and Alternate Fuels, based on uranium resources data developed under DOE National Uranium Resource Evaluation (NURE) programand the USGS Uranium Resource Assessment project, using methodology described in Uranium Resource Assessment by the Geological Survey: Methodology and Plan to Update the National Resource Base, U.S. Geological Survey Circular 994 (1987). 
Table B3. U.S. Uranium Reserves by Forward-Cost Category, 1986-1995 (Million Pounds $\mathrm{U}_{3} \mathrm{O}_{8}$ )

\begin{tabular}{|c|c|c|c|}
\hline Year & $\$ 30$ per pound & $\$ 50$ per pound & $\$ 100$ per pound \\
\hline 1986 & 322 & 1,036 & 1,630 \\
\hline 1987 & 304 & 1,005 & 1,592 \\
\hline 1988 & 289 & 981 & 1,560 \\
\hline 1989 & 277 & 962 & 1,537 \\
\hline 1990 & 265 & 926 & 1,511 \\
\hline 1991 & 304 & 975 & 1,542 \\
\hline 1992 & 295 & 959 & 1,523 \\
\hline 1993 & 292 & 952 & 1,511 \\
\hline 1994 & 294 & 953 & 1,501 \\
\hline 1995 & 290 & 947 & 1,493 \\
\hline
\end{tabular}

Note: Uranium reserves that could be recovered as a byproduct of phosphate and copper mining are not included in these reserves. Reserves values in forward-cost categories are cumulative; that is, the quantity at each level of forward cost includes all reserves at the lower costs.

Source: Estimated by the Energy Information Administration, Office of Coal, Nuclear, Electric and Alternated Fuels, based on U.S. Department of Energy, Grand Junction Projects Office data files and Energy Information Administration, Form ElA-858, "Uranium Industry Annual Survey" (1986-1995).

Table B4. Forward-Cost Uranium Reserves by State, 1995

\begin{tabular}{|c|c|c|c|c|c|c|}
\hline \multirow[b]{2}{*}{ State(s) } & \multicolumn{3}{|c|}{$\$ 30$ per pound } & \multicolumn{3}{|c|}{$\$ 50$ per pound } \\
\hline & $\begin{array}{c}\text { Ore } \\
\text { (million tons) } \\
\end{array}$ & $\begin{array}{c}\text { Grade } \\
\text { (percent } \mathrm{U}_{3} \mathrm{O}_{8} \text { ) }\end{array}$ & $\begin{array}{c}\mathrm{U}_{3} \mathrm{O}_{8} \\
\text { (million pounds) }\end{array}$ & $\begin{array}{c}\text { Ore } \\
\text { (million tons) }\end{array}$ & $\begin{array}{c}\text { Grade }^{\mathrm{a}} \\
\text { (percent } \mathrm{U}_{3} \mathrm{O}_{8} \text { ) }\end{array}$ & $\begin{array}{c}\mathbf{U}_{3} \mathrm{O}_{8} \\
\text { (million pounds) }\end{array}$ \\
\hline New Mexico .......................... & 15 & 0.278 & 84 & 111 & 0.157 & 350 \\
\hline 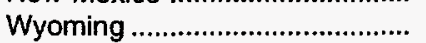 & 45 & 0.131 & 117 & 247 & 0.078 & 387 \\
\hline Arizona, Colorado, Utah ............. & 7 & 0.293 & 43 & 45 & 0.133 & 119 \\
\hline Texas & 6 & 0.099 & 11 & 22 & 0.068 & 29 \\
\hline Otherb & 9 & 0.203 & 35 & 27 & 0.111 & 61 \\
\hline$\ldots$ & 82 & 0.178 & 290 & 453 & 0.105 & 947 \\
\hline
\end{tabular}

aWeighted average percent $\mathrm{U}_{3} \mathrm{O}_{8}$ per ton of ore.

Includes California, Idaho, Nebraska, Nevada, North Dakota, Oregon, South Dakota, and Washington.

Notes: Uranium reserves that could be recovered as a byproduct of phosphate and copper mining are not included in this table. Reserves values in forward-cost categories are cumulative: that is, the quantity at each level of forward-cost includes all reserves at the lower costs. Totals may not equal sum of components because of independent rounding.

Sources: Estimated by Energy Information Administration, Office of Coal, Nuclear, Electric and Alternate Fuels, based on industry conferences, U.S. Department of Energy, Grand Junction Projects Office data files, and Energy Information Administration, Form EIA-858, "Uranium Industry Annual Survey" (1995) 
Appendix C

Respondents to the Uranium Industry Annual Survey 



\section{Appendix C}

\section{Respondents to the Uranium Industry Annual Survey}

Respondents to the Energy Information Administration's (EIA) 1995 Form EIA-858, "Uranium Industry Annual Survey," are listed alphabetically in Table C1. For each respondent, an industry-activity code (or codes) is shown. The activity code (codes) broadly describes the respondent's major industry activity from Form EIA-
858 and from publicly available information. Included in the listing are respondents that stated that no part of the Form ELA-858 was applicable to their operations as of the end of the survey year. The footnote at the end of Table $\mathrm{Cl}$ provides an explanation for the activity codes.

Table C1. Respondents to the 1995 Uranium Industry Annual Survey

\begin{tabular}{|c|c|c|c|}
\hline Company Name & $\begin{array}{c}\text { Industry } \\
\text { Activity } \\
\text { Code }\end{array}$ & Company Name & $\begin{array}{l}\text { Industry } \\
\text { Activity } \\
\text { Code }\end{array}$ \\
\hline Alabama Power Co. (Southern Nuclear) & UTL & Duquesne Light Company & UTL \\
\hline Albuquerque Uranium Corporation & UPH, BRO & Energy Fuels Nuclear Inc. & UPH, MLG \\
\hline American Electric Power Service Corp. & UTL & Enserch Exploration, Inc. & UPH \\
\hline Arizona Public Service Company & UTL & Entergy Operations, Inc. & UTL \\
\hline B \& W Fuel Company & $\mathrm{FAB}$ & Everest Exploration, Inc. & MLG \\
\hline B. B. Brooks Company & UPH & Florida Power Corporation & UTL \\
\hline Baltimore Gas and Electric & UTL & Florida Power and Light & UTL \\
\hline BGS Mining Company & UPH & General Electric Company & FAB \\
\hline Boston Edison Company & UTL & Geomex Minerals, inc. & UPH \\
\hline Cameco U.S. Inc. & UPH & George S. Fender & UPH \\
\hline Carolina Power \& Light & UTL & Georgia Power Co. (Southern Nuclear) & UTL \\
\hline Centerior Energy Corporation & UTL & GPU Nuclear Corporation & UTL \\
\hline Cobb Resources Corporation & UPH & Graves and Hudspeth Company & UPH \\
\hline Cogema, Inc. & BRO & Green Mountain Mining Venture & UPH, MLG \\
\hline Cogema Mining Inc. (Total Minerals Corp.) & UPH, MLG & Homestake Mining Company & UPH \\
\hline Combustion Engineering, Inc. & $F A B$ & Houston Lighting \& Power Co. & UTL \\
\hline Commonwealth Edison & UTL & IES Utilities, Inc. & UTL \\
\hline Consolidated Edison Co. of NY, Inc. & UTL & Illinois Power Company & UTL \\
\hline Consumers Power Company & UTL & IMC Global Operations & MLG \\
\hline ConverDyn & CON & Maine Yankee Atomic Power Co. & UTL \\
\hline Cotter Corporation & UPH, MLG & Malapai Resources Company & UPH, MLG \\
\hline Crow Butte Resources, Inc. & UPH, MLG & Marquez Development Corporation & UPH \\
\hline Cycle Resources Investment Corp. & BRO & Melvin Staats Company & UPH \\
\hline Dawn Mining Company & UPH,MLG & Mesa, Inc. & UPH \\
\hline DOE, Office of Uranium Programs & ENR & Mining Unlimited, Inc. & UPH \\
\hline Detrolt Edison & UTL & Nebraska Public Power District & UTL \\
\hline Duke Power Company & UTL & New Mexico Arizona Land Company & UPH \\
\hline
\end{tabular}


Table C1. Respondents to the 1995 Uranium Industry Annual Survey (Continued)

\begin{tabular}{|c|c|c|c|}
\hline Company Name & $\begin{array}{l}\text { Industry } \\
\text { Activity } \\
\text { Code }^{\mathrm{a}}\end{array}$ & Company Name & $\begin{array}{r}\text { Industry } \\
\text { Activity } \\
\text { Code" }\end{array}$ \\
\hline New York Power Authority & UTL & Section 2 Joint Venture-Continental Materials & UPH \\
\hline New York Nuclear Corp. /NYNCO Trading & BRO & Sheep Mountain Partners & UPH \\
\hline Niagara Mohawk Power Corporation & UTL & Siemens Power Corporation - Nuclear Div. & $\mathrm{FAB}$ \\
\hline Noranda Exploration, Inc. & UPH & Simons Associates & UPH \\
\hline North Atlantic Energy Service Corp. & UTL & South Carolina Electric \& Gas & UTL \\
\hline Northeast Utilities Service Co. & UTL & Southern California Edison Company & UTL \\
\hline Northern States Power Company & UTL & Noah H. \& Diane R. Taylor & UPH \\
\hline Nuclear Fuel Services, Inc. & UPH & Tennessee Valley Authority & UTL \\
\hline Nuexco Trading Corporation & TRA, BRO & Texas Utilities Electric Company & UTL \\
\hline Nukem, Inc. & TRA, BRO & UG U.S.A., Inc. & TRA \\
\hline Ohio Edison Co. and Pennsylvania Power & UTL & Umetco Minerals Corporation & UPH \\
\hline Omaha Public Power District & UTL & Union Electric Company & UTL \\
\hline Pacific Gas and Electric Company & UTL & United Nuclear Corporation & UPH \\
\hline Pathfinder Mines Corp. ( $\mathrm{C} / \mathrm{O}$ Cogema Inc.) & UPH & United States Enrichment Corporation & ENR \\
\hline PECO Energy Company & UTL & Uranerz USA, Inc. & UPH, BRO \\
\hline Pennsylvania Power \& Light Company & UTL & The Uranium Exchange Company & TRA, BRO \\
\hline Petrotomics Company (C/O Texaco, Inc) & UPH & Uranium King Corporation & UPH \\
\hline Power Resources, Inc. & UPH, MLG & Uranium Resources Incorporated & UPH, MLG \\
\hline Public Service Electric \& Gas & UTL & USX Corporation & UPH \\
\hline Rajah Ventures, Limited & UPH & U.S. Energy Corp. (Plateau Resources, Ltd) & UPH, MLG \\
\hline Rhone Poulenc, Inc. & MLG & Vermont Yankee Nuclear Power Corp. & UTL \\
\hline Rio Algom Mining Corp. & UPH, MLG & Virginia Electric and Power Co. & UTL \\
\hline Rio Grande Resources Corp. & UPH & Washington Public Power Supply System & UTL \\
\hline Riverside Public Utility Dept. & UTL & Western Nuclear, Inc. & UPH \\
\hline RME Partners, L. P. & UPH & Westinghouse Electric Corporation & FAB \\
\hline Rochester Gas \& Electric Corporation & UTL & Wisconsin Electric Power Company & UTL \\
\hline Sacramento Municipal Utility Dist. & UTL & Wisconsin Public Service Corporation & UTL \\
\hline San Diego Gas and Electric & UTL & Wold Nuclear Company, John S. Wold d/b/a & UPH \\
\hline San Rafael Energy, Inc. & UPH & Wolf Creek Nuclear Operating Coporation & UTL \\
\hline
\end{tabular}

"BRO = Uranium brokerage company; $C O N=$ Uranium conversion service supplier; ENR = Uranium enrichment service supplier; FAB = Uranium fuel fabrlcation service supplier; MLG = Uranium milling/processing company (can involve ownership of a uranium property); TRA = Uranium trading company; $\mathrm{UPH}=$ Uranium property holder (can include activities related to uranium exploration, reserves, reclamation, and/or mining); UTL = Nuclear electric utility company.

Source: Prepared by the Energy Information Administration, Office of Coal, Nuclear, Electric and Alternate Fuels, based on information reported on the Form EIA-858 "Uranium Industry Annual Survey" (1995). 
Appendix D

U.S. Customary Units of Measurement, International System of Units (SI), and Selected Data Tables in SI Metric Units 



\section{Appendix D}

\section{U.S. Customary Units of Measurement, International System of Units (SI), and Selected Data Tables in SI Metric Units}

Standard Factors for interconversion between U.S. customary units and the International System of Units (SI) are shown in Table D1. These factors are provided as a coherent and consistent set of units for the convenience of the reader in making conversions between U.S. and metric units of measure for data published in this report. Conversion factors are provided only for the U.S. units of measurement quoted in this report.

Table D1. Conversion Factors for U.S. Customary Units and SI Metric Units of Measurement

\begin{tabular}{|c|c|c|}
\hline To convert from: & To: & Multiply by: ${ }^{\mathrm{a}}$ \\
\hline \multicolumn{3}{|c|}{ Area } \\
\hline acre & meter ${ }^{2}\left(m^{2}\right)$ & $4,046.9^{\star}$ \\
\hline \multicolumn{3}{|c|}{ Length } \\
\hline $\begin{array}{l}\text { foot }(\mathrm{ft}) \\
\text { yard }(\mathrm{yd})\end{array}$ & $\begin{array}{l}\text { meter }(m) \\
\text { meter }(m)\end{array}$ & $\begin{array}{l}0.304801 \\
0.9144^{*}\end{array}$ \\
\hline \multicolumn{3}{|c|}{ Mass } \\
\hline $\begin{array}{l}\text { pound-avoirdupois (lb avdp) } \\
\text { pound-avoirdupois } \mathrm{U}_{3} \mathrm{O}_{8}{ }^{\mathrm{b}} \\
\text { ton, short }(2,000 \mathrm{lb})\end{array}$ & $\begin{array}{l}\text { kilogram }(\mathrm{kg}) \\
\text { kilogram } U \\
\text { metric ton }(\mathrm{t})\end{array}$ & $\begin{array}{l}0.453592 \\
0.384647 \\
0.907185\end{array}$ \\
\hline
\end{tabular}

"An asterisk after the last digit indicates that the conversion factor is exact and that all subsequent digits are zero. All other conversion factors are rounded to six digits after the decimal.

The factor of 1 pound $U_{3} O_{0} \quad 0.848002$ pounds $U$ was used in this conversion.

Source: Table E1 is patterned after Table 3, "Conversion Factors for SI Metric Units and U.S. Customary Units of Measurement," in S.M. Long and A.M. Orellana, "The Metric System," in Suggestions to Authors of the Reports of the United States Geological Survey, Sixth Edition, U.S. Government Printing Office (Washington, DC, 1978) pp. 192-196. 


\section{Forward Cost and Average Price Conversions}

The forward-cost categories of \$US80 through \$US260 per pound U shown on Table D3 to report uranium reserves quantities were converted from units of " $\$$ per pound $\mathrm{U}_{3} \mathrm{O}_{8}$ " to "\$ per kilogram U" by multiplying by the standard factor of 2.6 and rounding the results to the nearest multiple of \$US10.

\section{Selected Tables Converted to SI Metric Values}

Sixteen principal tables of data from the Uranium Industry Annual 1995 (UIA) converted to equivalent metric values are shown on the following pages. The crosswalk given below shows the correlation between the tables of metric values and their corresponding tables in U.S. customary units in the main body of the UIA.

\section{Appendix D Table Number}

\section{UIA Chapter and Table Number}

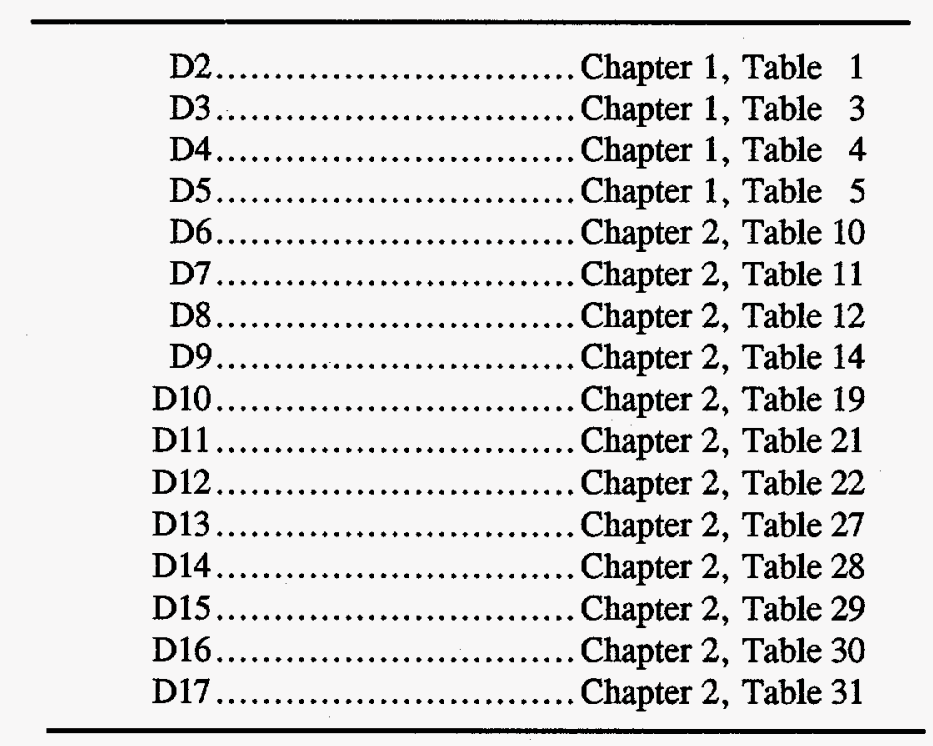


Table D2. U.S. Uranium Land and Surface Drilling Activities, 1986-1995

\begin{tabular}{|c|c|c|c|c|c|c|c|c|c|c|c|}
\hline \multirow[b]{2}{*}{ Year } & \multicolumn{2}{|c|}{$\begin{array}{l}\text { Land } \\
\text { Exploration }\end{array}$} & \multicolumn{3}{|c|}{$\begin{array}{l}\text { Surface Drilling } \\
\text { Exploration }\end{array}$} & \multicolumn{3}{|c|}{$\begin{array}{l}\text { Surface Drilling } \\
\text { Development }\end{array}$} & \multicolumn{3}{|c|}{$\begin{array}{l}\text { Surface Drilling } \\
\text { Exploration and Development }\end{array}$} \\
\hline & \begin{tabular}{|c|} 
Square \\
Meters \\
Acquired \\
during \\
Year \\
(millions) \\
\end{tabular} & \begin{tabular}{|c|} 
Square \\
Meters \\
Held at \\
End of \\
Year \\
(millions)
\end{tabular} & $\begin{array}{l}\text { Number } \\
\text { of Holes }\end{array}$ & $\begin{array}{c}\text { Meters } \\
\text { (thousand) }\end{array}$ & $\begin{array}{c}\text { Cost" } \\
\text { (thousand } \\
\text { dollars) }\end{array}$ & $\begin{array}{l}\text { Number } \\
\text { of Holes }\end{array}$ & $\begin{array}{c}\text { Meters } \\
\text { (thousand) }\end{array}$ & $\begin{array}{c}\text { Cost" } \\
\text { (thousand } \\
\text { dollars) }\end{array}$ & $\begin{array}{l}\text { Number } \\
\text { of Holes }\end{array}$ & $\begin{array}{c}\text { Meters } \\
\text { (thousand) }\end{array}$ & $\begin{array}{c}\text { Cost" } \\
\text { (thousand } \\
\text { dollars) }\end{array}$ \\
\hline $1986 \ldots$ & 890 & 10,700 & 1,985 & 335 & 6,400 & 1,846 & 296 & 1,350 & 3,831 & 631 & 7,750 \\
\hline $1987 \ldots$ & 364 & 7,900 & 1,820 & & & 1,994 & & & 14 & 60 & 6,960 \\
\hline $1988 \ldots . .$. & 364 & 6,880 & 2,029 & 390 & 6,440 & 3,176 & 527 & 3,260 & 5,205 & 917 & 9,700 \\
\hline $1989 \ldots$ & 113 & 6,188 & 2,087 & 436 & 5,820 & 1,753 & 244 & 3,120 & 3,840 & 680 & 8,940 \\
\hline $1990 \ldots$ & 154 & 4,893 & 1,507 & 265 & 3,210 & 1,908 & 247 & 5,950 & 3,415 & 512 & 9,160 \\
\hline $1991 \ldots$. & 130 & 4,290 & 1,624 & 297 & 2,832 & 1,573 & 265 & 8,114 & 3,197 & 561 & 10,946 \\
\hline $1992 \ldots$. & 344 & 3,189 & 935 & 171 & 1,267 & 833 & 153 & 1,162 & 1,768 & 324 & 2,429 \\
\hline $1993 \ldots$ & 263 & 1,843 & 355 & 68 & 983 & 1,665 & 270 & 4,754 & 2,020 & 338 & 5,737 \\
\hline $1994 \ldots$ & 36 & 1,315 & 519 & 104 & 736 & 477 & 96 & 383 & 996 & 200 & 1,119 \\
\hline $1995 \ldots$ & 28 & 1,048 & 584 & 123 & 790 & 1,728 & 289 & 1,799 & 2,312 & 411 & 2,589 \\
\hline
\end{tabular}

${ }^{a}$ Costs for 1986 through 1990 were rounded to the nearest $\$ 10$ thousand.

Note: Totals may not equal sum of components because of independent rounding.

Sources: Energy Information Administration: 1986-1994-Uranium Industry Annual 1994 (July 1995). 1995-Form ElA-858, "Uranium Industry Annual Survey" (1995).

Table D3. Forward-Cost Uranium Reserves by Mining Method, 1995

\begin{tabular}{|c|c|c|c|c|c|c|}
\hline \multirow[b]{3}{*}{ Mining Method } & \multicolumn{6}{|c|}{ Forward-Cost Category } \\
\hline & \multicolumn{3}{|c|}{$\$ 30$ per pound } & \multicolumn{3}{|c|}{$\$ 50$ per pound } \\
\hline & $\begin{array}{c}\text { Ore } \\
\text { (million } \\
\text { metric tons) }\end{array}$ & $\underset{\text { (percent U) }}{\text { Grade }^{n}}$ & $\begin{array}{l}\text { Uranium } \\
\text { (thousand } \\
\text { metric tons) }\end{array}$ & $\begin{array}{c}\text { Ore } \\
\text { (million } \\
\text { metric tons) }\end{array}$ & $\begin{array}{c}\text { Grade }^{\circ} \\
\text { (percent U) }\end{array}$ & $\begin{array}{c}\text { Uranium } \\
\text { (thousand } \\
\text { metric tons) }\end{array}$ \\
\hline 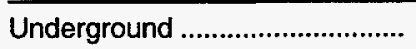 & 23 & 0.232 & 53 & 130 & 0.138 & 179 \\
\hline 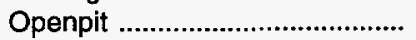 & 9 & 0.118 & 11 & 148 & 0.067 & 99 \\
\hline In Situ Leaching ............................ & 42 & 0.113 & 47 & 119 & 0.067 & 80 \\
\hline 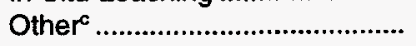 & $<1$ & 0.224 & $<1$ & 14 & 0.042 & 6 \\
\hline Total & 74 & 0.151 & 112 & 411 & 0.089 & 364 \\
\hline
\end{tabular}

a Weighted average percent $U$ per metric ton of ore.

Includes Califomia, Idaho, Nebraska, Nevada, North Dakota, Oregon, South Dakota, and Washington.

Includes heap leach, mine water, and low grade stockpiles.

Notes: Uranium reserves that could be recovered as a byproduct of phosphate and copper mining are not included in this table. Reserves values in forward-cost categories are cumulative: That is, the quantity at each level of forward-cost includes all reserves at the lower costs. Totals may not equal sum of components because of independent rounding.

Sources: Estimated by Energy Information Administration, Office of Coal, Nuclear, Electric and Altemate Fuels, based on industry conferences, U.S. Department of Energy, Grand Junction Projects Office data files, and Energy Information Administration, Form ElA-858, "Uranium Industry Annual Survey" (1995). 
Table D4. U.S. Uranium Mine Production and Number of Mines and Sources, 1986-1995

\begin{tabular}{|c|c|c|c|c|c|c|c|c|c|c|}
\hline Mining Method & 1986 & 1987 & 1988 & 1989 & 1990 & 1991 & 1992 & 1993 & 1994 & 1995 \\
\hline $\begin{array}{l}\text { Underground } \\
\text { (metric tons } U \text { ) }\end{array}$ & 2,500 & 1,900 & 2,100 & 2,000 & W & W & W & 0 & 0 & 0 \\
\hline $\begin{array}{l}\text { Openpit } \\
\text { (metric tons } U \text { ) }\end{array}$ & $W$ & W & W & W & 724 & 972 & W & 0 & 0 & 0 \\
\hline $\begin{array}{l}\text { In Situ Leaching } \\
\text { (metric tons U) }\end{array}$ & w & $w$ & w & W & w & W & W & W & 942 & 1,297 \\
\hline $\begin{array}{l}\text { Other } \\
\text { (metric tons } U)\end{array}$ & 700 & 400 & 1,600 & 1,700 & 1,537 & 1,021 & 379 & 789 & 30 & 60 \\
\hline $\begin{array}{l}\text { Total Mine Production } \\
\text { (metric tons U) }\end{array}$ & 3,200 & 2,300 & 3,700 & 3,700 & 2,260 & 1,993 & 379 & 789 & 972 & 1,357 \\
\hline 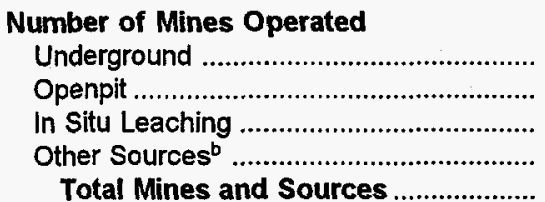 & $\begin{array}{r}13 \\
4 \\
12 \\
2 \\
31\end{array}$ & $\begin{array}{r}19 \\
2 \\
15 \\
1 \\
37\end{array}$ & $\begin{array}{r}17 \\
4 \\
11 \\
0 \\
32\end{array}$ & $\begin{array}{r}19 \\
2 \\
9 \\
2 \\
32\end{array}$ & $\begin{array}{r}27 \\
2 \\
7 \\
3 \\
39\end{array}$ & $\begin{array}{r}6 \\
2 \\
6 \\
1 \\
15\end{array}$ & $\begin{array}{r}4 \\
1 \\
4 \\
8 \\
17\end{array}$ & $\begin{array}{r}0 \\
0 \\
5 \\
7 \\
12\end{array}$ & $\begin{array}{r}0 \\
0 \\
5 \\
7 \\
12\end{array}$ & $\begin{array}{r}0 \\
0 \\
5 \\
7 \\
12\end{array}$ \\
\hline
\end{tabular}

aFor 1986 through 1989, "Other" includes production from openpit, in situ leach, heap leach, mine water, and water-treatment plant solutions. Production quantities were rounded to the nearest 100 metric tons. For 1990 and 1991, "Other" includes production from underground, in situ leach, heap leach (1990), mine water, water treatment plant solutions (1990), and restoration. For 1992, "Other" includes production from underground, openpit, and in situ leach mines and uranium bearing water from mine workings, tailings ponds, and restoration. For 1993, the "Other" includes production from in situ leach mines and urainum bearing water from mine workings and restoration. For 1994 and 1995, "Other" includes uranium bearing water from mine workings and restoration.

'Other Sources includes, in various years, heap leach, mine water, mill site cleanup and mill tailings, well field restoration, and low-grade stockpiles as sources of uranium.

$W=$ Data withheld to avoid disclosure. The data are included in the total for "Other."

Notes: Totals may not equal sum of components because of independent rounding. Table does not include byproduct production and sources.

Sources: Energy Information Administration: 1986-1994-Uranium Industry Annnual 1994 (July 1995); 1995-Form ElA-858, "Uranium Industry Annual Survey" (1995). 
Table D5. U.S. Uranium Concentrate Processing Operations, 1986-1995

\begin{tabular}{|c|c|c|c|c|c|c|c|c|c|c|}
\hline Processing Operations & 1986 & 1987 & 1988 & 1989 & 1990 & 1991 & 1992 & 1993 & 1994 & 1995 \\
\hline $\begin{array}{l}\text { Ore Fed to Process } \\
\text { (thousand metric tons) }\end{array}$ & 1,187 & 1,307 & 1,101 & 1,120 & 655 & 580 & 232 & 0 & 0 & 151 \\
\hline 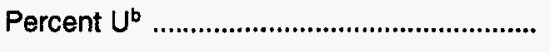 & 0.285 & 0.241 & 0.244 & 0.274 & 0.248 & 0.168 & 0.194 & -- & -- & 0.441 \\
\hline 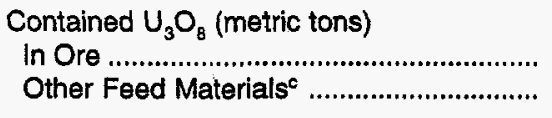 & $\begin{array}{r}3,378 \\
100\end{array}$ & $\begin{array}{r}3,150 \\
182\end{array}$ & $\begin{array}{r}2,692 \\
195\end{array}$ & $\begin{array}{r}3,068 \\
165\end{array}$ & $\begin{array}{r}1,626 \\
187\end{array}$ & $\begin{array}{r}973 \\
69\end{array}$ & $\begin{array}{r}451 \\
70\end{array}$ & $\begin{array}{r}0 \\
16\end{array}$ & $\begin{array}{r}0 \\
30\end{array}$ & $\begin{array}{r}669 \\
63\end{array}$ \\
\hline Total Mill Feed (metric tons U) ...................... & 3,478 & 3,333 & 2,887 & 3,233 & 1,812 & 1,042 & 520 & 16 & 30 & 732 \\
\hline $\begin{array}{l}\text { In-Process Inventory Change } \\
\text { (metric tons U) }\end{array}$ & -25 & -81 & 52 & -90 & .94 & -47 & -10 & 4 & 9 & 60 \\
\hline $\begin{array}{l}\text { Concentrate Produced at Mills } \\
\text { (metric tons U) }\end{array}$ & & & & & & & & & & \\
\hline Theoreticald & $\begin{array}{l}3,503 \\
3,405\end{array}$ & $\begin{array}{l}3,413 \\
3,283\end{array}$ & $\begin{array}{l}2,834 \\
2,706\end{array}$ & $\begin{array}{l}3,323 \\
3,144\end{array}$ & $\begin{array}{l}1,906 \\
1,788\end{array}$ & $\begin{array}{l}1,089 \\
1,003\end{array}$ & $\begin{array}{l}530 \\
523\end{array}$ & $\begin{array}{l}12 \\
12\end{array}$ & $\begin{array}{l}21 \\
18\end{array}$ & $\begin{array}{l}671 \\
621\end{array}$ \\
\hline Recovery as Percent of Total Mill Feed ..... & 97.2 & 96.2 & 95.5 & 94.6 & 93.8 & 92.2 & 98.7 & 96.8 & 85.2 & 92.6 \\
\hline $\begin{array}{l}\text { Tailings and Unaccountable } \\
\text { (metric tons U) }\end{array}$ & 98 & 130 & 129 & 179 & 118 & 85 & 7 & 0 & 3 & 50 \\
\hline $\begin{array}{l}\text { Other Processing } \\
\text { (metric tons } U \text { ) }\end{array}$ & 1,790 & 1,714 & 2,345 & 2,178 & 1,630 & 2,056 & 1,649 & 1,167 & 1,272 & 1,703 \\
\hline 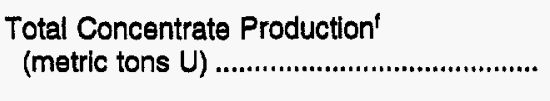 & 5,195 & 4,997 & 5,050 & 5,322 & 3,418 & 3,059 & 2,171 & 1,178 & 1,289 & 2,324 \\
\hline $\begin{array}{l}\text { Total Concentrate Shipped From Milis } \\
\text { and Plants } \\
\quad \text { (metric tons U) } \ldots \ldots \ldots \ldots \ldots \ldots \ldots \ldots \ldots \ldots \ldots \ldots \ldots \ldots \ldots \ldots \ldots \ldots \ldots \ldots \ldots \ldots\end{array}$ & 4,093 & 4,446 & 4,920 & 5,696 & 4,984 & 3,245 & 2,636 & 1,298 & 2,431 & 2,116 \\
\hline
\end{tabular}

auranium ore "fed to process" in any year can include: ore mined and shipped to a mill during the same year, ore that was mined during a prior year and later shipped from mine-slte stockplles, and/or ore obtained from drawdowns of stockpiles maintalned at a mlli site.

bWeighted average percent $U$ per metric ton of ore.

Includes for varlous years uranlum from low-grade ore, mill cleanup, mine water, tallings water, and heap leaching, except as footnoted below.

"At 100-percent recovery. This equals total mill feed minus in-process inventory change.

$-\mathrm{U}_{3} \mathrm{O}_{8}$ concentrate production from in situ leaching and as a byproduct of other processing. The totals for 1986 through 1988 include $\mathrm{U}_{3} \mathrm{O}_{8}$ recovered from reclamation and mine water at some mills that did not report processing of uranium ore for those years.

'Total does not Include uranium concentrate production from pilot projects or other research project sources.

-.=Not appllcable.

Note: Totals may not equal sum of components because of independent rounding.

Sources: Energy Information Administration: 1986-1994-Uranlum Industry Annnual 1994 (July 1995); 1995-Form ElA-858, "Uranlum Industry Annual Survey" (1995). 
Table D6. U.S. Utilities Contracted Uranium by Supplier, Transaction Type, and Delivery Year, 1994-1995

(Metric Tons U Equivalent; Dollars per Kilogram U Equivalent)

\begin{tabular}{|c|c|c|}
\hline Actual Deliveries & 1994 & 1995 \\
\hline \multicolumn{3}{|l|}{ Received by U.S. Utilities from U.S. Producers: } \\
\hline 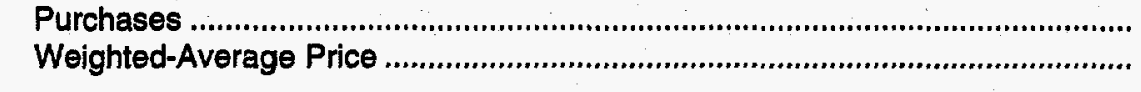 & $\begin{array}{l}2,093 \\
35.68\end{array}$ & $\begin{array}{l}2,034 \\
38.59\end{array}$ \\
\hline \multicolumn{3}{|l|}{ Received by U.S. Utilities from U.S. Brokers and Traders: } \\
\hline 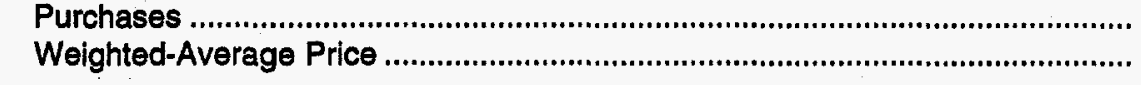 & $\begin{array}{l}5,879 \\
24.29\end{array}$ & $\begin{array}{l}6,232 \\
25.56\end{array}$ \\
\hline \multicolumn{3}{|l|}{ Received by U.S. Utilities from other U.S. Utilities: } \\
\hline Purchases & 0 & 0 \\
\hline 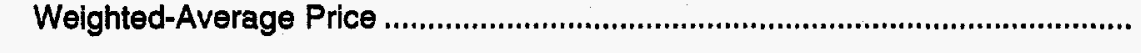 & -- & $\ldots$ \\
\hline \\
\hline $\begin{array}{l}\text { Purchases } \\
\text { Weighted-Average Price }\end{array}$ & $\begin{array}{r}420 \\
20.90\end{array}$ & $\begin{array}{r}216 \\
32.56\end{array}$ \\
\hline \multicolumn{3}{|l|}{ Received by U.S. Utilities from Foreign Suppliers: } \\
\hline Purchases c.Average Price & $\begin{array}{l}6,332 \\
27.11\end{array}$ & $\begin{array}{l}8,227 \\
29.63\end{array}$ \\
\hline \multicolumn{3}{|l|}{ Total Recelved by U.S. UtIlIties: } \\
\hline Purchases & 14,725 & 16,709 \\
\hline 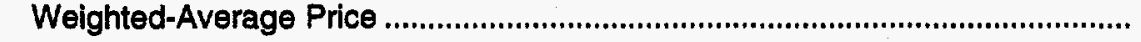 & 27.03 & 29.24 \\
\hline
\end{tabular}

$--=$ Not applicable

Note: "Other U.S. suppliers" are U.S. converters, entichers, and fabricators.

Source: Energy Information Adminlatration, Form ElA-858, "Uranium Industry Annual Survey" (1994-1995).

Table D7. U.S. Utilities Contracted Uranium by Transaction Type and Delivery Year, 1994-1995 (Metric Tons U Equivalent; Dollars per Kilogram U Equivalent)

\begin{tabular}{|c|c|c|}
\hline Actual Deliveries & 1994 & 1995 \\
\hline \multicolumn{3}{|l|}{ Received by U.S. Utilities of U.S.-Origin Uranium: } \\
\hline Purchases & $\begin{array}{l}2,969 \\
31.39\end{array}$ & $\begin{array}{l}2,018 \\
36.93\end{array}$ \\
\hline \multicolumn{3}{|l|}{ Received by U.S. Utilities of Foreign-Origin Uranium: } \\
\hline Purchases & $\begin{array}{r}11,756 \\
25.92\end{array}$ & $\begin{array}{r}14,692 \\
28.18\end{array}$ \\
\hline \multicolumn{3}{|l|}{ Total: } \\
\hline Purchases & $\begin{array}{r}14,725 \\
27.03\end{array}$ & $\begin{array}{r}16,709 \\
29.24\end{array}$ \\
\hline
\end{tabular}

Note: Totals may not equal sum of components because of independent rounding.

Source: Energy Information Administration, Form EIA-858, "Uranium Industry Annual Survey" (1994-1995). 
Table D8. U.S. Utilitles Purchases of Uranium by Origin Country and Delivery Year, 1994-1995 (Metric Tons U Equivalent; Dollars per Kilogram U Equivalent)

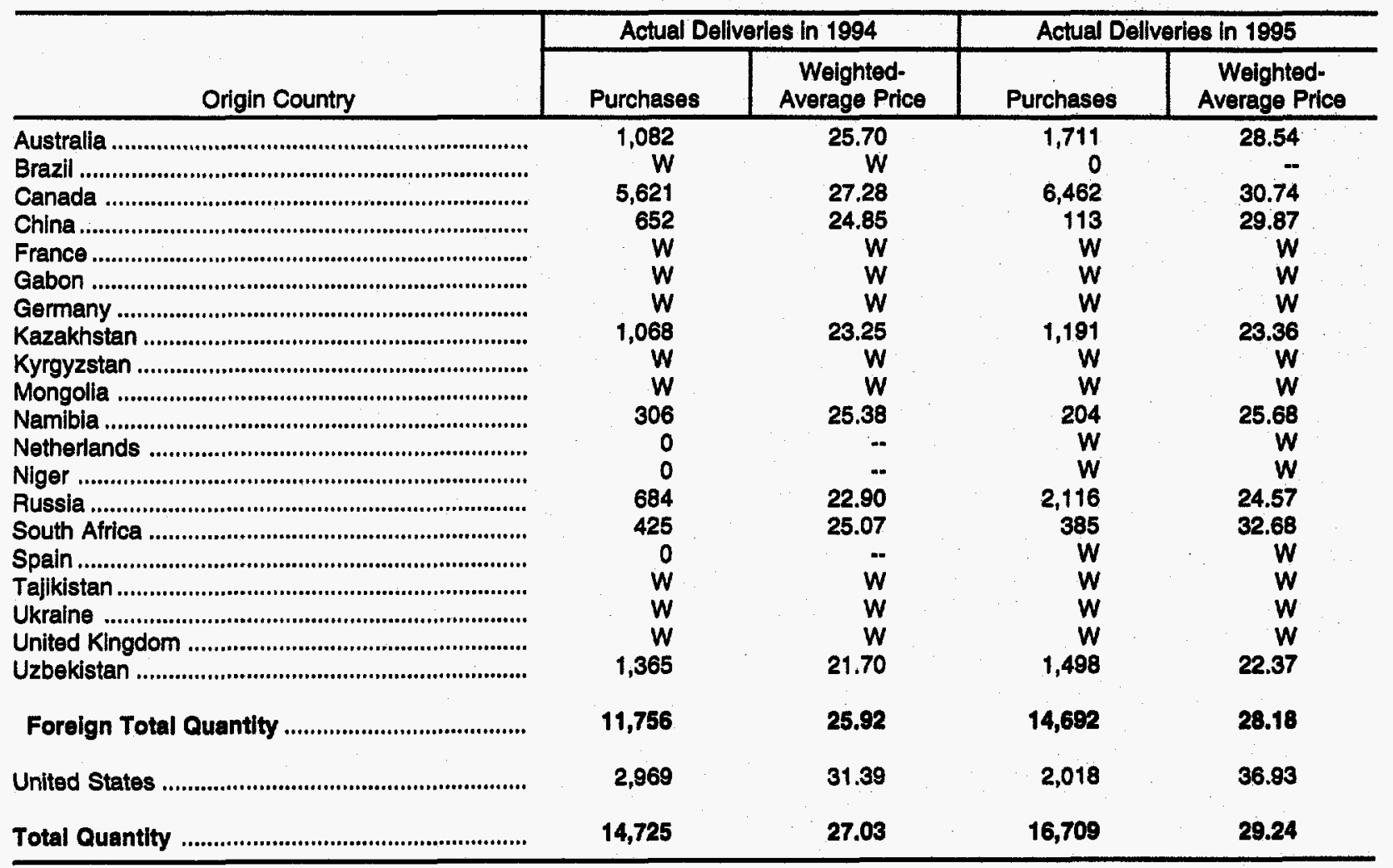

$W=$ Data witheld to avoid disclosure.

$-=$ Not applicable.

Sources: Energy Information Administration: 1994-Uranium Industy Annual 1994 (July 1995); 1995-Form ElA-858, "Uranium Industry Annual Survey" (1995). 
Table D9. Average Price and Quantity for Purchases of Uranium by U.S. Utilities by Pricing Mechanisms and Delivery Year, 1994-1995

(Dollars per Kilogram U Equivalent; Metric Tons U Equivalent)

\begin{tabular}{|c|c|c|c|c|c|c|}
\hline \multirow[b]{2}{*}{ Pricing Mechanisms } & \multicolumn{2}{|c|}{ Domestic Purchases } & \multicolumn{2}{|c|}{ Foreign Purchases } & \multicolumn{2}{|c|}{ Total Purchases } \\
\hline & 1994 & 1995 & 1994 & 1995 & 1994 & 1995 \\
\hline 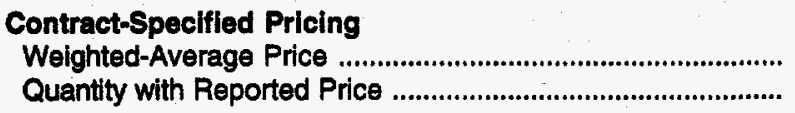 & $\begin{array}{l}27.76 \\
4,290\end{array}$ & $\begin{array}{l}27.50 \\
6,564\end{array}$ & $\begin{array}{r}30.98 \\
957\end{array}$ & $\begin{array}{l}33.69 \\
2,148\end{array}$ & $\begin{array}{l}28.34 \\
5,248\end{array}$ & $\begin{array}{l}29.02 \\
8,712\end{array}$ \\
\hline 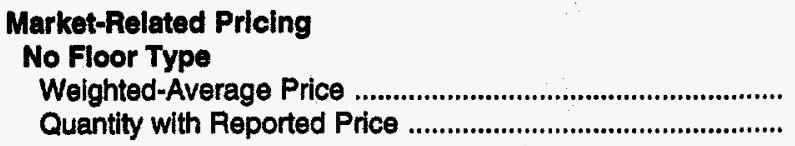 & $\begin{array}{l}25.38 \\
2,724\end{array}$ & $\begin{array}{r}26.48 \\
815\end{array}$ & $\begin{array}{l}23.94 \\
3,181\end{array}$ & $\begin{array}{l}28.22 \\
3,184\end{array}$ & $\begin{array}{l}24.60 \\
5,905\end{array}$ & $\begin{array}{l}27.86 \\
3,999\end{array}$ \\
\hline 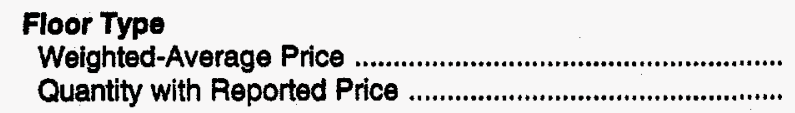 & $\begin{array}{r}52.07 \\
233\end{array}$ & $\begin{array}{r}46.42 \\
263\end{array}$ & $\begin{array}{l}30.68 \\
1,500\end{array}$ & $\begin{array}{l}28.19 \\
1,651\end{array}$ & $\begin{array}{l}33.55 \\
1,733\end{array}$ & $\begin{array}{l}30.69 \\
1,913\end{array}$ \\
\hline 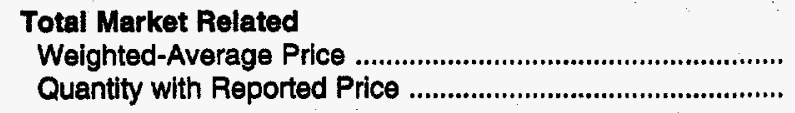 & $\begin{array}{l}27.48 \\
2,958\end{array}$ & $\begin{array}{l}31.34 \\
1,078\end{array}$ & $\begin{array}{l}26.10 \\
4,680\end{array}$ & $\begin{array}{l}28.21 \\
4,835\end{array}$ & $\begin{array}{l}26.63 \\
7,638\end{array}$ & $\begin{array}{l}28.78 \\
5,912\end{array}$ \\
\hline 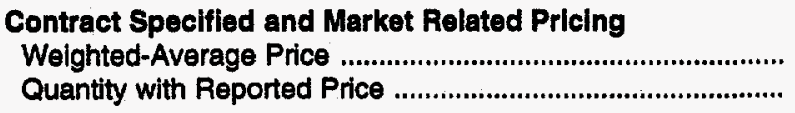 & $\begin{array}{l}27.64 \\
7,248\end{array}$ & $\begin{array}{l}28.04 \\
7,642\end{array}$ & $\begin{array}{l}26.93 \\
5,638\end{array}$ & $\begin{array}{l}29.89 \\
6,982\end{array}$ & $\begin{array}{r}27.33 \\
12,886\end{array}$ & $\begin{array}{r}28.92 \\
14,624\end{array}$ \\
\hline 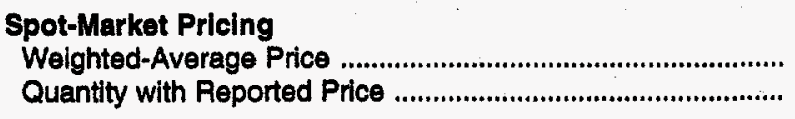 & $\begin{array}{r}24.37 \\
275\end{array}$ & $\begin{array}{r}23.59 \\
288\end{array}$ & $\ddot{0}$ & $\begin{array}{r}26.68 \\
656\end{array}$ & $\begin{array}{r}24.37 \\
275\end{array}$ & $\begin{array}{r}25.74 \\
944\end{array}$ \\
\hline 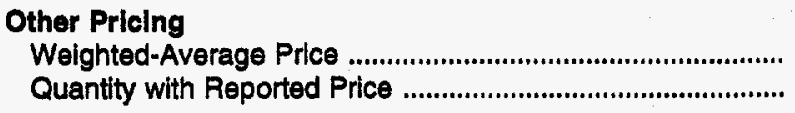 & $\begin{array}{l}22.25 \\
1,226\end{array}$ & $\begin{array}{r}41.27 \\
649\end{array}$ & $\begin{array}{r}34.91 \\
338\end{array}$ & $\begin{array}{r}29.47 \\
492\end{array}$ & $\begin{array}{l}24.99 \\
1,564\end{array}$ & $\begin{array}{l}36.18 \\
1,141\end{array}$ \\
\hline 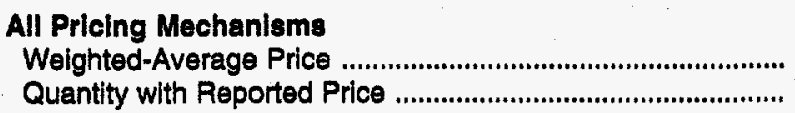 & $\begin{array}{l}26.79 \\
8,749\end{array}$ & $\begin{array}{l}28.89 \\
8,578\end{array}$ & $\begin{array}{l}27.38 \\
5,976\end{array}$ & $\begin{array}{l}29.61 \\
8,131\end{array}$ & $\begin{array}{r}27.03 \\
14,725\end{array}$ & $\begin{array}{r}29.24 \\
16,709\end{array}$ \\
\hline
\end{tabular}

-..Not applicable.

Note: Totals may not equal sum of componentins because of Independent rounding.

Source: Energy Information Administration, Form ElA-858, "Uranium Industry Annual Survey" (1994-1995).

Table D10. U.S. Utilitles Contracted Purchases of Uranium from Suppliers, In Effect at the End of 1995, by Delivery Year, 1996-2005

(Metric Tons U Equivalent)

\begin{tabular}{|c|c|c|c|c|c|c|}
\hline \multirow[b]{2}{*}{ Year of Delivery } & \multicolumn{2}{|c|}{$\begin{array}{l}\text { Purchases from U.S. } \\
\text { Suppliers }\end{array}$} & \multicolumn{2}{|c|}{$\begin{array}{l}\text { Purchases from Foreign } \\
\text { Suppliers }\end{array}$} & \multicolumn{2}{|c|}{$\begin{array}{l}\text { Purchases from All } \\
\text { Suppllers }\end{array}$} \\
\hline & $\begin{array}{c}\text { Firm } \\
\text { Deliveries }\end{array}$ & $\begin{array}{l}\text { Optlonal } \\
\text { Dellverles }\end{array}$ & $\begin{array}{c}\text { Firm } \\
\text { Delliveries }\end{array}$ & $\begin{array}{l}\text { Optional } \\
\text { Dellveries }\end{array}$ & $\begin{array}{c}\text { Firm } \\
\text { Deliveries }\end{array}$ & $\begin{array}{l}\text { Optional } \\
\text { Deliveries }\end{array}$ \\
\hline 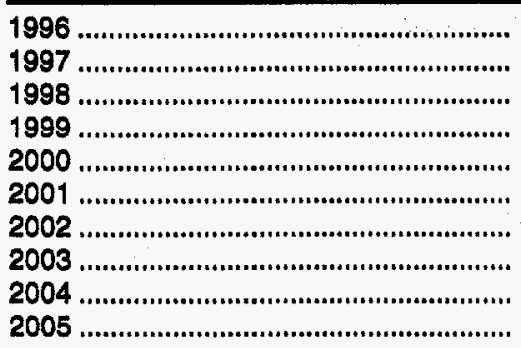 & $\begin{array}{r}5,332 \\
4,331 \\
3,499 \\
1,948 \\
2,224 \\
1,318 \\
1,252 \\
297 \\
260 \\
37\end{array}$ & $\begin{array}{r}829 \\
1,174 \\
1,003 \\
422 \\
682 \\
292 \\
405 \\
520 \\
289 \\
289\end{array}$ & $\begin{array}{r}\mathbf{6 , 9 6 1} \\
\mathbf{5 , 5 3 0} \\
\mathbf{5 , 6 0 6} \\
\mathbf{3 , 1 2 0} \\
\mathbf{3 , 6 2 8} \\
1,369 \\
\mathbf{7 4 6} \\
\mathbf{5 4} \\
\mathbf{5 4} \\
\mathbf{5 4}\end{array}$ & $\begin{array}{r}1,413 \\
1,788 \\
1,844 \\
1,503 \\
1,006 \\
1,225 \\
1,120 \\
802 \\
569 \\
569\end{array}$ & $\begin{array}{r}12,293 \\
9,841 \\
9,105 \\
5,068 \\
5,852 \\
2,686 \\
1,997 \\
351 \\
314 \\
91\end{array}$ & $\begin{array}{r}2,241 \\
2,962 \\
2,846 \\
1,924 \\
1,688 \\
1,517 \\
1,525 \\
1,322 \\
859 \\
859\end{array}$ \\
\hline 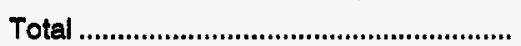 & 20,478 & 5,904 & 27,121 & 11,839 & 47,599 & 17,743 \\
\hline
\end{tabular}

Note: Totals may not equal sum of components because of independent rounding

Source: Energy Information Administration, Form EIA-858, "Uranlum Industry Annual Survey" (1995). 
Table D11. Anticipated Uranium Market Requirements of U.S. Utilities, 1996-2005, as of December 31, 1995

(Metric Tons U Equivalent)

\begin{tabular}{|c|c|c|c|c|}
\hline Year & $\begin{array}{l}\text { Quantity of Uranium Under } \\
\text { Purchase Contracts }\end{array}$ & $\begin{array}{c}\text { Unfilled } \\
\text { Requirements }\end{array}$ & $\begin{array}{l}\text { Anticipated Market } \\
\text { Requirements }\end{array}$ & $\begin{array}{l}\text { Enrichment Feed } \\
\text { Deliveries }\end{array}$ \\
\hline $1996 \ldots \ldots . . . \ldots . . .$. & 14,535 & 1,947 & 16,482 & 18,878 \\
\hline $1997 \ldots \ldots . . . . . . . .$. & 12,803 & 3,187 & 15,990 & 16,225 \\
\hline $1998 \ldots \ldots \ldots . . . . . . . .$. & 11,951 & 6,042 & 17,994 & 20,362 \\
\hline 1999 & 7,304 & 8,924 & 16,228 & 14,514 \\
\hline $2000 \ldots \ldots \ldots . . . . . . . .$. & 7,540 & 13,269 & 20,809 & 18,319 \\
\hline $2001 \ldots \ldots \ldots \ldots$ & 4,218 & 16,386 & 20,604 & 13,488 \\
\hline $2002 \ldots \ldots \ldots \ldots$ & 3,522 & 16,611 & 20,133 & 14,747 \\
\hline 2003 & 1,673 & 18,830 & 20,504 & 13,927 \\
\hline $2004 \ldots \ldots \ldots \ldots$ & 1,173 & 18,738 & 19,911 & 15,522 \\
\hline 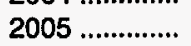 & 949 & 16,832 & 17,781 & 11,683 \\
\hline Total .................. & 65,669 & 120,766 & 186,435 & 157.664 \\
\hline
\end{tabular}

Note: Totals may not equal sum of components because of independent rounding.

Source: Energy Information Administration, Form EIA-858, "Uranium Industry Annual Survey" (1995).

Table D12. U.S. Utilities Deliveries of Uranium Feed by Enrichment Country and Delivery Year, 1994-1995

(Metric Tons U Equivalent)

\begin{tabular}{|c|c|c|c|c|c|c|}
\hline \multirow[b]{2}{*}{ Enrichment Plant Location } & \multicolumn{3}{|c|}{ Actual Deliveries in 1994} & \multicolumn{3}{|c|}{ Actual Deliveries in 1995} \\
\hline & U.S.-Origin & $\begin{array}{c}\text { Foreign- } \\
\text { Origin }\end{array}$ & Total & U.S.-Origin & $\begin{array}{c}\text { Foreign- } \\
\text { Origin } \\
\end{array}$ & Total \\
\hline China & $w$ & w & w & 0 & 0 & 0 \\
\hline France & w & W & 427 & w & w & 1,741 \\
\hline 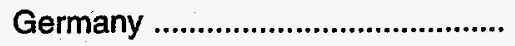 & 0 & 0 & 0 & w & w & 335 \\
\hline 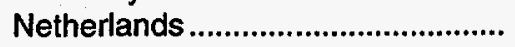 & 0 & $\mathbf{w}$ & 389 & w & w & 366 \\
\hline Russia & W & w & 517 & 322 & 721 & 1,043 \\
\hline South Africa & 0 & 0 & 0 & 0 & 0 & 0 \\
\hline 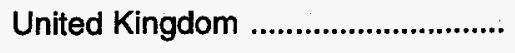 & 0 & W & W & 0 & 407 & 407 \\
\hline 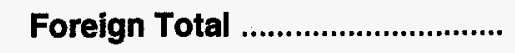 & 20 & 1,561 & 1,581 & 535 & 3,463 & 3,998 \\
\hline 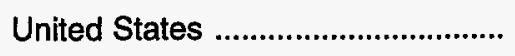 & 3,258 & 9,627 & 12,885 & 2,995 & 10,045 & 13,040 \\
\hline Total & 3,278 & 11,188 & 14,466 & $\mathbf{3 , 5 3 0}$ & 13,508 & 17,038 \\
\hline
\end{tabular}

W=Data withheld to avoid disclosure.

Note: Totals may not equal sum of components because of independent rounding.

Sources: Energy Information Administration: 1994-Uranium Industry Annual 1994 (July 1995); 1995-Form ElA-858, "Uranium Industry Annual Survey" (1995).

Table D13. Uranium Loaded into Fuel Assemblies for Commercial Nuclear Reactors by Year, 1994-1995

(Metric Tons U Equivalent)

\begin{tabular}{|c|c|c|}
\hline Origin of Uranium & 1994 & $1995^{P}$ \\
\hline 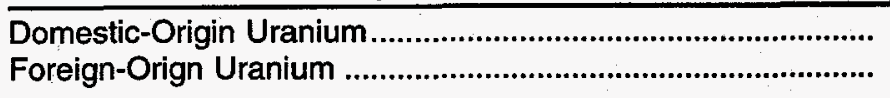 & $\begin{array}{r}\mathrm{R} 3,578 \\
\mathrm{R} 11,962\end{array}$ & $\begin{array}{r}4,287 \\
15,375\end{array}$ \\
\hline Total & $\mathrm{R} 15,540$ & 19,662 \\
\hline
\end{tabular}

$P=$ Preliminary data. $R=$ Revised data. Final 1994 tinal assembly data reported in the 1995 survey.

Notes: Includes only unirradiated uranium in new fuel assemblles loaded into reaclors during the year. Does not include uranium removed from reactors that subsequently will be reloaded. Totals may not eaqual sum of components because of independent rounding.

Source: Energy Information Administration, Form EIA-858, "Uranium Industry Annual Survey" (1995). 
Table D14. Imports of Uranium by U.S. Suppliers, U.S. Utilities and Delivery Year, 1994-1995 (Metric Tons U Equivalent; Dollars per Kilograms U Equivalent)

\begin{tabular}{|c|c|c|}
\hline Actual Deliveries & 1994 & 1995 \\
\hline 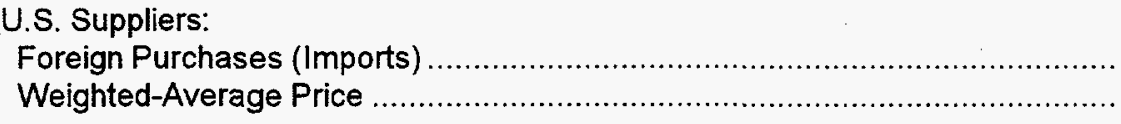 & $\begin{array}{l}8,109 \\
20.23\end{array}$ & $\begin{array}{l}7,755 \\
23.29\end{array}$ \\
\hline 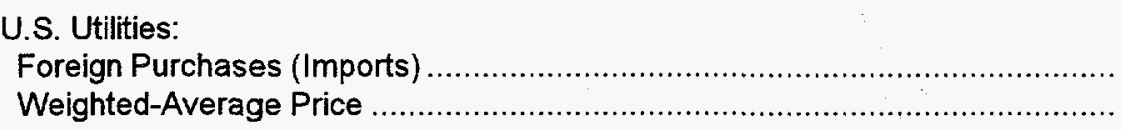 & $\begin{array}{l}5,976 \\
27.38\end{array}$ & $\begin{array}{l}8,131 \\
29.61\end{array}$ \\
\hline 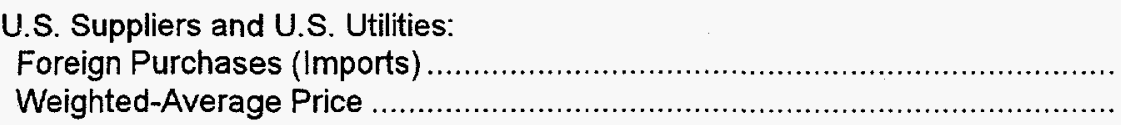 & $\begin{array}{r}14,085 \\
23.27\end{array}$ & $\begin{array}{r}15,886 \\
26.52\end{array}$ \\
\hline
\end{tabular}

Source: Energy Information Administration, Form EIA-858, "Uranium Industry Annual Survey" (1994-1995).

Table D15. U.S. Brokers and Traders Purchases of Uranium by Material Origin, Supplier, and Delivery Year, 1994-1995 (Metric Tons U Equivalent; Dollars per Kilogram U Equivalent)

\begin{tabular}{|c|c|c|}
\hline Actual Deliveries & 1994 & 1995 \\
\hline 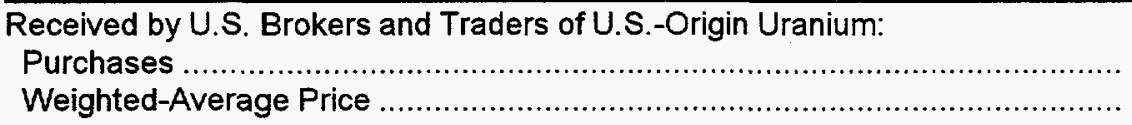 & $\begin{array}{l}1,843 \\
25.35\end{array}$ & $\begin{array}{l}1,291 \\
29.91\end{array}$ \\
\hline 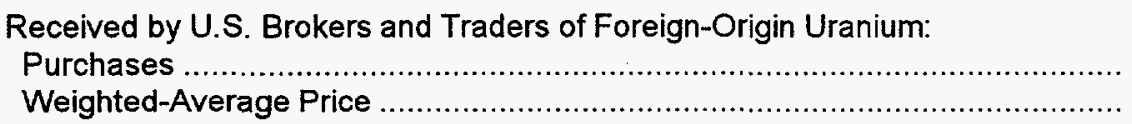 & $\begin{array}{r}10,005 \\
20.86\end{array}$ & $\begin{array}{l}7,536 \\
23.91\end{array}$ \\
\hline 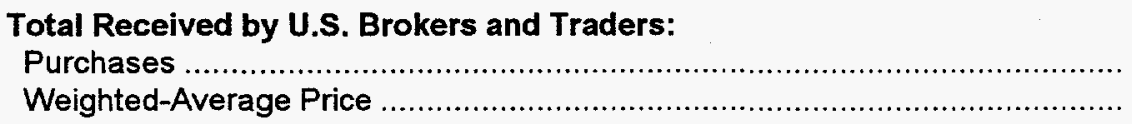 & $\begin{array}{r}11,848 \\
21.56\end{array}$ & $\begin{array}{l}8,827 \\
24.79\end{array}$ \\
\hline 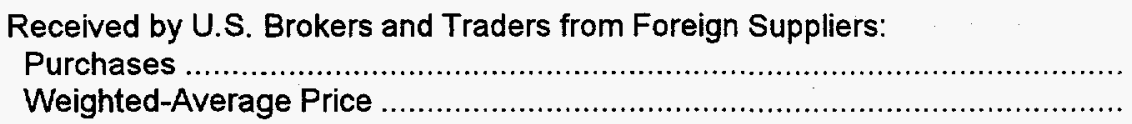 & $\begin{array}{l}8,588 \\
20.46\end{array}$ & $\begin{array}{l}7,043 \\
23.46\end{array}$ \\
\hline
\end{tabular}

Note: Tolals may not equal sum of components because of independent rounding.

Source: Energy Information Administration, Form EIA-858, "Uranium Industry Annual Survey" (1994-1995). 
Table D16. Uranium Exports to Foreign Suppliers and Utilities by Origin and Delivery Year, 1994-1995

(Metric Tons U Equivalent; Dollars per Kilogram U Equivalent)

\begin{tabular}{|c|c|c|}
\hline Actual Deliveries to Foreign Suppliers and Utilities & 1994 & 1995 \\
\hline 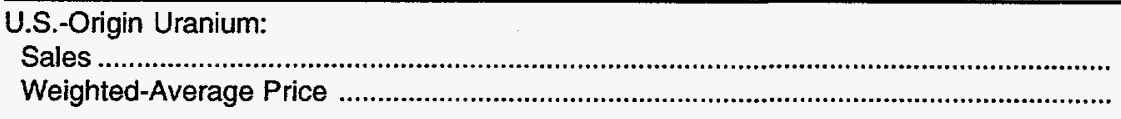 & $\begin{array}{l}2,285 \\
47.86\end{array}$ & $\begin{array}{l}1,813 \\
45.07\end{array}$ \\
\hline 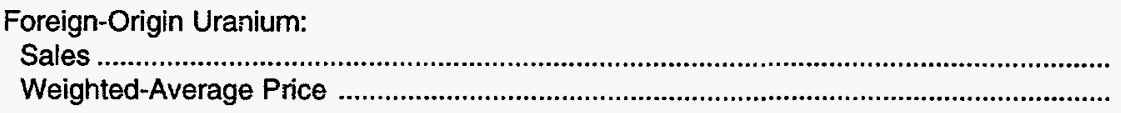 & $\begin{array}{l}4,538 \\
20.24\end{array}$ & $\begin{array}{l}1,971 \\
25.84\end{array}$ \\
\hline 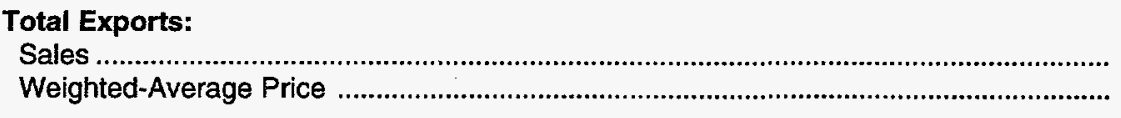 & $\begin{array}{l}6,824 \\
29.49\end{array}$ & $\begin{array}{l}3,783 \\
35.06\end{array}$ \\
\hline $\begin{array}{l}\text { Exports by U.S. Producers, U.S. Utilities, and Other Suppliers: } \\
\text { Sales } \\
\text { Weighted-Average Price }\end{array}$ & $\begin{array}{l}1,896 \\
52.23\end{array}$ & $\begin{array}{l}1,670 \\
47.08\end{array}$ \\
\hline 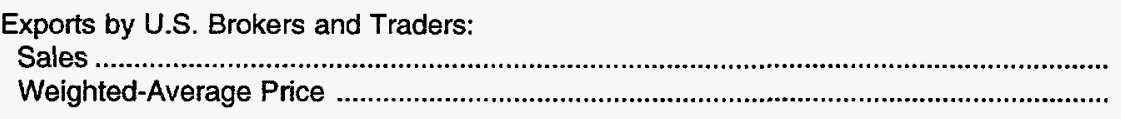 & $\begin{array}{l}4,927 \\
20.73\end{array}$ & $\begin{array}{l}2,113 \\
25.55\end{array}$ \\
\hline
\end{tabular}

Note: "Other U.S. Suppliers" are U.S. converters, enrichers, and fabricators.

Source: Energy Information Administration, Form ElA-858, "Uranium Industry Annual Survey" (1994-1995).

Table D17. Inventories of Natural and Enriched Uranium as of End of Year, 1994-1995 (Metric Tons U Equivalent)

\begin{tabular}{|c|c|c|}
\hline \multirow[b]{2}{*}{ Type of Uranium Inventory } & \multicolumn{2}{|c|}{ Inventories at the End of the Year } \\
\hline & 1994 & $1995^{P}$ \\
\hline 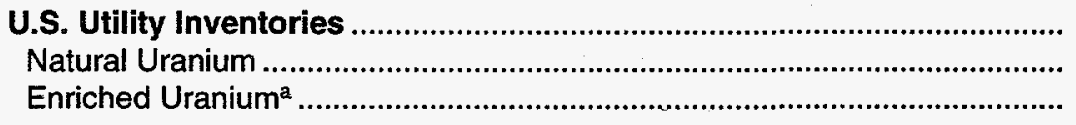 & $\begin{array}{r}\mathbf{R} 25,160 \\
R 16,316 \\
R 8,844\end{array}$ & $\begin{array}{r}21,622 \\
15,562 \\
6,061\end{array}$ \\
\hline 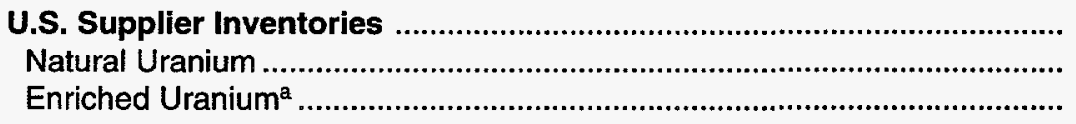 & $\begin{array}{l}R 8,258 \\
R 6,698 \\
R 1,560\end{array}$ & $\begin{array}{r}5,353 \\
5,195 \\
158\end{array}$ \\
\hline 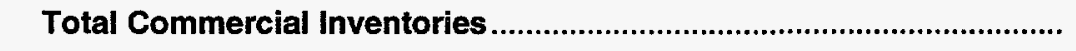 & R33,418 & 26,975 \\
\hline 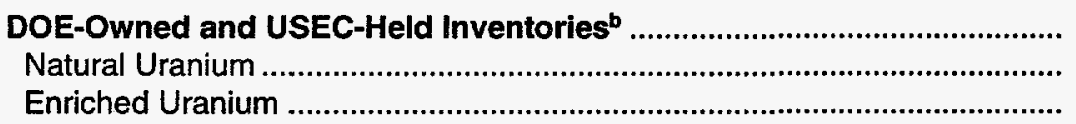 & $\begin{array}{l}\mathbf{R} 32,776 \\
\mathrm{R} 21,993 \\
\mathrm{R} 10,783\end{array}$ & $\begin{array}{l}42,616 \\
31,534 \\
11,081\end{array}$ \\
\hline
\end{tabular}

ancludes amounts reported as inventories of $U F_{6}$ at Enrichment Suppliers.

bAmounts reported as inventories by U.S. Department of Energy (DOE) and the United States Enrichment Corporation (USEC).

$P=$ Preliminary data. $R=$ Revised data. Final 1994 inventory data reported in the 1995 survey

Note: Totals may not equal sum of components because of independent rounding.

Source: Energy Information Administration, Form EIA-858, "Uranium Industry Annual Survey" (1995). 

Glossary 



\section{Glossary}

Contract-specified price: The delivery price determined when a contract is signed. It can be a fixed price or a base price escalated according to a given formula.

Conventional mill (uranium): A facility engineered and built principally for processing of uraniferous ore materials mined from the earth and the recovery, by chemical treatment in the mill's circuits, of uranium and/or other valued coproduct components from the processed ore.

Cost model for undiscovered resources: A computerized algorithm that uses the uranium endowment estimated for a given geological area and selected industry economic indexes to develop random variables that describe the undiscovered resources ultimately expected to be discovered in that area at chosen forward-cost categories.

Cutoff grade: The lowest grade, in percent $\mathrm{U}_{3} \mathrm{O}_{8}$, of uranium ore at a minimum specified thickness that can be mined at specified cost.

Development drilling: Drilling done to determine more precisely size, grade, and configuration of an ore deposit subsequent to the time the determination is made that the deposit can be commercially developed.

Domestic: Domestic means within the 50 States, District of Columbia, Puerto Rico, the Virgin Islands, Guam, and other U.S. possessions. The word "domestic" is used also in conjunction with data and information that are compiled to characterize a particular segment or aspect of the uranium industry in the United States.

Domestic purchase: A uranium purchase from a firm located in the United States.

Domestic sale: A uranium sale to a firm located in the United States.
Domestic uranium industry: Collectively, those businesses (whether U.S. or foreign-based) that operate under the laws andregulations pertaining to the conduct of commerce within the United States and its territories and possessions and that engage in activities within the United States, its territories, and possessions specifically directed toward uranium exploration, development, mining, and milling; marketing of uranium materials; enrichment; fabrication; or acquisition and management of uranium materials for use in commercial nuclear power plants.

Enriched uranium: Uranium in which the ${ }^{235} \mathrm{U}$ isotope concentration has been increased to greater than the 0.711 percent ${ }^{235} \mathrm{U}$ (by weight) present in natural uranium.

Enrichment feed deliveries: Uranium that is shipped under contract to a supplier of enrichment services for use in preparing enriched uranium product to a specified ${ }^{235} \mathrm{U}$ concentration and that ultimately will be used as fuel in a nuclear reactor.

Enrichment services: (See Separative Work Units).

Exploration drilling: Drilling done in search of new mineral deposits, on extensions of known ore deposits, or at the location of a discovery up to the time when the company decides that sufficient ore reserves are present to justify commercial exploitation. Assessment drilling is reported as exploration drilling.

Fabricated fuel: Fuel assemblies composed of an array of fuel rods loaded with pellets of enriched uranium dioxide.

Floor price: A price specified in a market-price contracts as the lowest purchase price of the uranium, even if the market price falls below the specified price. The floor price may be related to the seller's production costs.

Foreign purchase: $A$ uranium purchase of foreign-origin uranium from a firm located outside of the United States. 
Foreign sale: A uranium sale to a firm located outside the United States.

Forward cost: The operating and capital costs still to be incurred in the production of uranium from in-place reserves. By using forward costing, estimates of reserves for ore deposits in differing geological settings and status of development can be aggregated and reported for selected cost categories. Included are costs for labor, materials, power and fuel, royalties, payroll taxes, insurance, and applicable general and administrative costs. Excluded from forward cost estimates are prior expenditures, if any, incurred for property acquisition, exploration, mine development, and mill construction, as well as income taxes, profit, and the cost of money. Forward costs are neither the full costs of production nor the market price at which the uranium, when produced, might be sold.

Heap leach solutions: The separation, or dissolving-out, from mined rock of the soluble uranium constituents by the natural action of percolating a prepared chemical solution through mounded (heaped) rock material. The mounded material usually contains low grade mineralized material and/or waste rock produced from openpit or underground mines. The solutions are collected after percolation is completed and processed to recover the valued components.

In situ leach mining (ISL): The recovery, by chemical leaching, of the valuable components of an orebody without physical extraction of the ore from the ground. Also referred to as "solution mining."

Long-term contract: One or more deliveries to occur after a period of at least 6 years following contract execution.

Market-related price: The prevailing price level in the market at a given time. It generally reflects a published spot price, is mutually agreed upon by the contracting parties, or is independently determined by an unbiased outside arbitrator.
Market-price contract: A contract in which the price of uranium is not specifically determined at the time the contract is signed but is based instead on the prevailing market price at the time of delivery. A market-price contract may include a floor price, that is, a lower limit on the eventual settled price. The floor price and the method of price escalation generally are determined when the contract is signed. The contract may also include a price ceiling or a discount from the agreed-upon market price reference.

Market-price settlement: The price paid for uranium delivery under a market-price contract. The price is commonly (but not always) determined at or sometime before delivery and may be related to a floor price, ceiling price, or discount.

Medium-term contract: One or more deliveries to occur over a period of 3 to 6 years following contract execution.

Milling of uranium: The processing of uranium from ore mined by conventional methods, such as underground or openpit methods, to separate the uranium from the undesired material in the ore.

National Uranium Resource Evaluation (NURE): A program begun by the U.S. Atomic Energy Commission (AEC) in 1974 to make a comprehensive evaluation of U.S. uranium resources and continued through 1983 by the AEC's successor agencies, the Energy Research and Development Administration (ERDA) and the Department of Energy (DOE). The NURE program included aerial radiometric and magnetic surveys, hydrogeochemical and stream sediment surveys, geologic drilling in selected areas, geophysical logging of selected boreholes, and geologic studies to identify and evaluate geologic environments favorable for uranium.

Nonconventional plant (uranium): A facility engineered and built principally for processing of uraniferous solutions that are produced during in situ leach mining, from heap leaching, or in the manufacture of other commodities, and the recovery, by chemical treatment in the plant's circuits, of uranium from the processed solutions. 
Nuclear reactor: An apparatus in which a nuclear fission reaction, i.e., the splitting of atomic nuclei to release heat energy, can be initiated, controlled, and sustained at a specific rate. A reactor includes fuel (fissionable material), moderating materials to control the rate of fissioning, a heavy-walled pressure vessel to house reactor components, shielding to protect personnel, a system to conduct heat away from the reactor, and instrumentation for monitoring and controlling the reactor's systems.

Optional delivery commitment: A provision to allow the conditional purchase or sale of a specific quantity of material in addition to the firm quantity in the contract.

Processing of uranium: The recovery of uranium from solutions produced by nonconventioanl mining methods, i.e., in situ leach mining (ISL), a byproduct of copper or phosphate mining, or heap leaching.

Reclamation: Process of restoring surface environment to acceptable pre-existing conditions. Includes surface contouring, equipment removal, well plugging, revegetation, etc.

Restoration: The returning of all affected groundwater to its premining quality for its premining use by employing the best practical technology.

Separative Work Units (SWU): The standard nieasure of enrichment services. The effort expended in separating a mass $F$ of feed of assay $x f$ into a mass $P$ of product assay $x p$ and waste of mass $W$ and assay $x w$ is expressed in terms of the number of separative work units needed, given by the expression $S W U=W V\left(x_{w}\right)+P V\left(x_{p}\right)-$ $F V\left(x_{f}\right)$, where $V(x)$ is the "value function," defined as $\mathrm{V}(\mathrm{x})=(1-2 \mathrm{x}) \ln ((1-\mathrm{x}) / \mathrm{x})$.

Short-term contract: One or more deliveries to occur over a period of less than 3 years following contract execution .

Spot contract: A one-time delivery of the entire contract to occur within one year of contract execution.

Spot market: Buying and selling of uranium for immediate or very near-term delivery. It typically involves transactions for delivery of up to 500,000 pounds $\mathrm{U}_{3} \mathrm{O}_{8}$ within a year of contract execution.
Spot-market price: A transaction price concluded "on the spot," that is, on a one-time, prompt basis. The transaction usually involves only one specific quantity of product. This contrasts with a term-contract sale price, which obligates the seller to deliver a product at an agreed frequency and price over an extended period.

Unfilled requirements: Requirements not covered by usage of inventory or supply contracts in existence as of January 1 of the survey year.

Uranium: A heavy, naturally radioactive, metallic element (atomic number 92). Its two principally occurring isotopes are ${ }^{235} \mathrm{U}$ and ${ }^{238} \mathrm{U}$. The isotope ${ }^{235} \mathrm{U}$ is indispensable to the nuclearindustry because it is the only isotope existing in nature to any appreciable extent that is fissionable by thermal neutrons. The isotope ${ }^{238} \mathrm{U}$ is also important because it absorbs neutrons to produce a radioactive isotope that subsequently decays to the isotope ${ }^{239} \mathrm{Pu}$, which also is fissionable by thermal neutrons.

Uranium concentrate: A yellow or brown powder produced from naturally occurring uranium minerals as a result of milling uranium ore or processing uraniumbearing solutions. Synonymous with yellowcake, $\mathrm{U}_{3} \mathrm{O}_{8}$, or uranium oxide.

Uranium deposit: A discrete concentration of uranium mineralization that is of possible economic interest.

Uranium endowment: The uranium that is estimated to occur in rock with a grade of at least 0.01 percent $\mathrm{U}_{3} \mathrm{O}_{8}$. The estimate of the uranium endowment is made before consideration of economic availability and any associated uranium resources.

Uranium hexafluoride (UF 6 ): A white solid obtained by chemical treatment of $\mathrm{U}_{3} \mathrm{O}_{8}$ and which forms a vapor at temperatures above 56 degrees Centigrade. $\mathrm{UF}_{6}$ is the form of uranium required for the enrichment process.

Uranium ore: Rock containing uranium mineralization in concentrations that can be mined economically, (typically 1 to 4 pounds of $\mathrm{U}_{3} \mathrm{O}_{8}$ per ton or 0.05 to 0.20 percent $\mathrm{U}_{3} \mathrm{O}_{8}$ ).

Uranium oxide: Uranium concentrate or yellowcake. Abbreviated as $\mathrm{U}_{3} \mathrm{O}_{8}$. 
Uranium property: A specific piece of land with uranium reserves that is held for the ultimate purpose of economically recovering the uranium. The land can be developed for production or undeveloped.

Uranium reserves: Estimated quantities of uranium in known mineral deposits of such size, grade, and configuration that the uranium could be recovered at or below a specified production cost with currently proven mining and processing technology and under current law and regulations. Reserves are based on direct radiometric and chemical measurements of drill holes and other types of sampling of the deposits. Mineral grades and thickness, spatial relationships, depths below the surface, mining and reclamation methods, distances to milling facilities, and amenability of ores to processing are consideredin the evaluation. The amount of uranium in ore that could be exploited within the chosen forward-cost levels are estimated in accordance with conventional engineering practices.

Uranium resources categories: Three categories of uranium resources are used to reflect differing levels of confidence in the resources reported. Reasonably assured resources (RAR), estimated additional resources (EAR), and speculative resources (SR) are described below.

Reasonably assured resources (RAR): The uranium that occurs in known mineral deposits of such size, grade, and configuration that it could be recovered within the given production cost ranges, with currently proven mining and processing technology. Estimates of tonnage and grade are based on specific sample data and measurements of the deposits and on knowledge of deposit characteristics. RAR correspond to DOE's uranium reserves category. Estimated additional resources (EAR): The uranium in addition to RAR that is expected to occur, mostly on the basis of direct geological evidence, in extensions of well-explored deposits, little explored deposits, and undiscovered deposits believed to exist along well-defined geological trends with known deposits, such that the uranium can subsequently be recovered within the given cost ranges. Estimates of tonnage and grade are based on available sampling data and on knowledge of the deposit characteristics, as determined in the best-known parts of the deposit or in similar deposits. EAR correspond to DOE's probable potential resources category.

Speculative resources (SR): Uranium in addition to EAR that is thought to exist, mostly on the basis of indirect evidence and geological extrapolations, in deposits discoverable with existing exploration techniques. The locations of deposits in this category can generally be specified only as being somewhere within given regions or geological trends. The estimates in this category are less reliable than estimates of RAR and EAR. The category of SR corresponds to DOE's possible potential resources plus speculative potential resources categories combined.

Usage Agreement: Contracts held by enrichment customers that allow feed material to be stored at the enrichment plant site in advance of need.

Yellowcake: (See uranium oxide). 